\title{
Final Report MELTING
}

Impact of MELTING permafrost and rock glaciers on water quality and aquatic organisms in alpine lakes

Karin A. Koinig , Günter Köck, Sergi Pla, Elena \& Boris Ilyashuk, Reinhard Lackner, Roland Psenner

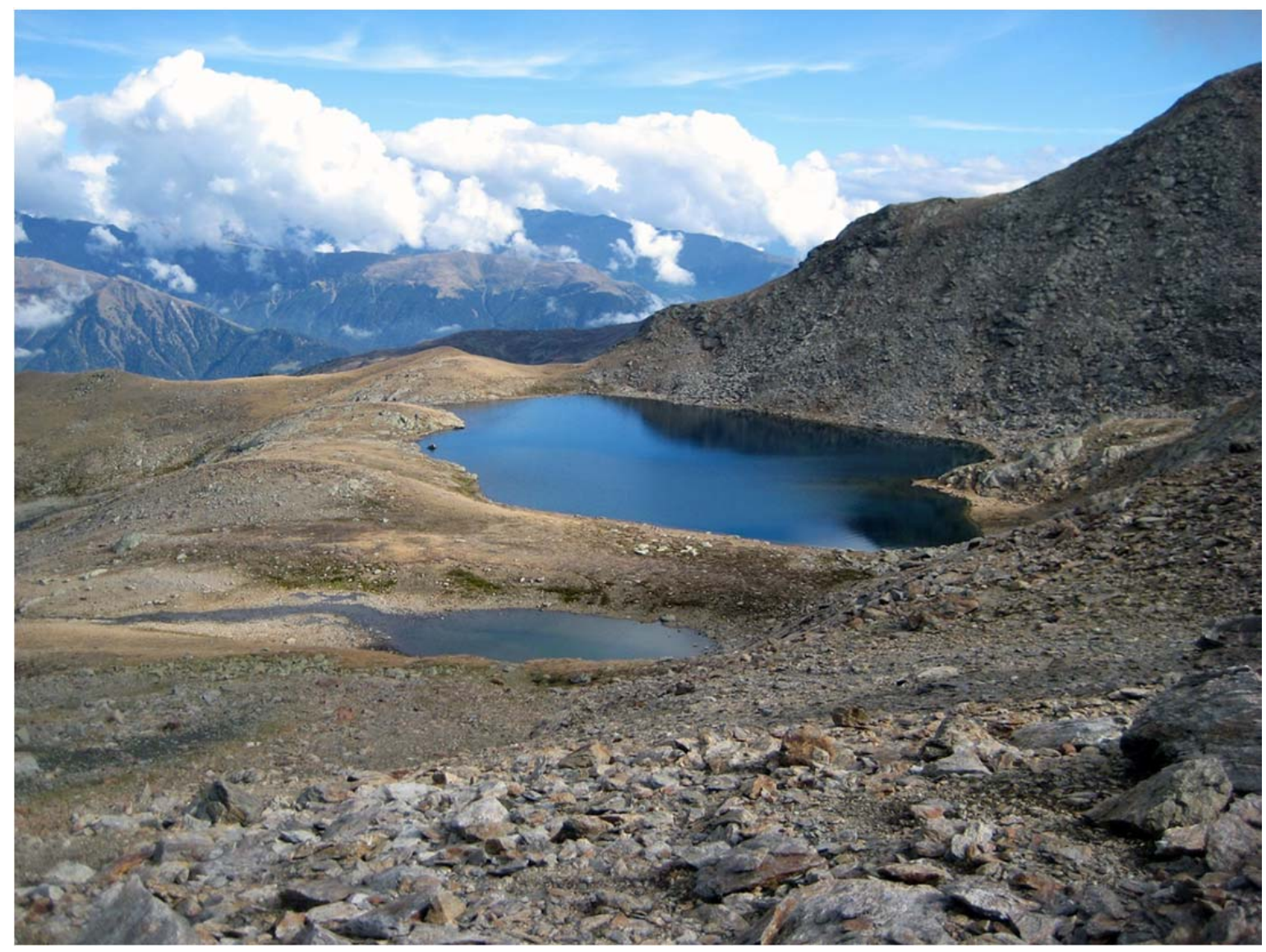

Study site Rasass See and rock glacier on the N-facing slopes (photo: K.Koinig) 
ISBN-Online: 978-3-7001-7813-2

DOI: 10.1553/ALP-IMP 


\section{Table of contents}

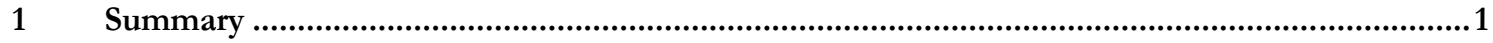

1.1 Answers to the research questions addressed within this project 2

1.2 Summary of additional observations 3

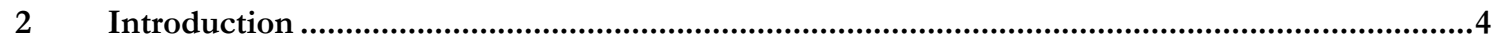

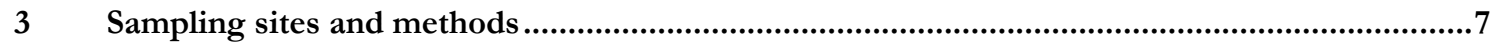

$\begin{array}{lll}3.1 & \text { Study sites } & 7\end{array}$

3.2 Water analyses $\quad 8$

3.3 Living aquatic organisms 9

3.4 Sediment cores 9

3.5 Diatoms in the sediment core 10

3.6 Chironomids in the sediment core 10

3.7 Physical and geochemical methods $\quad 10$

3.8 Data handling and statistics 11

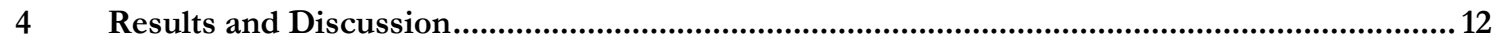

4.1 Seasonal variations of basic limnochemical parameters in Rasass See 12

4.2 Nickel variation in water samples from Rasass See 13

4.3 Nickel variation in water samples of 25 different water bodies 14

4.4 Nickel variation in the sediment of Rasass See 16

$\begin{array}{lll}4.5 & \text { Effects on diatoms } & 20\end{array}$

4.6 Effects on chironomids and other invertebrates 24

$\begin{array}{lll}4.8 & \text { Metal accumulation in fish } & 27\end{array}$

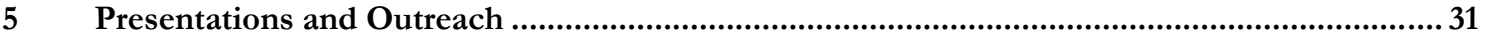

5.1 Publications 31

5.2 Master Thesis carried out in cooperation with this project 31

5.3 BAK Theses supervised within this project 31

5.4 Oral presentations 31

5.5 Posterpresentations 32

5.6 Documentation for Television $\quad 32$

5.7 Print media/public outreach 33

$\begin{array}{lll}5.8 & \text { Internet } & 33\end{array}$

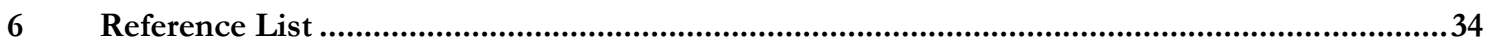




\section{SUMMARY}

Here we summarize four years of investigations of the impact of thawing rock glaciers on fresh water bodies. The study was carried out on 25 water bodies, including lakes, ponds and their effluents, affected strongly, moderately or not at all by rock glacier melt water.

From the lake most strongly affected by rock glacier melt water, we obtained a short sediment core which we analysed for sediment geochemistry (with special interest in trace metal variations), diatoms, and chironomids. In addition, this lake was frequently sampled for limnochemical analyses which showed strong seasonal variations of conductivity, $\mathrm{pH}$ and metal content attributed to the lake's mixing pattern and to subsurface permafrost meltwater inflow into the lake. By investigating the outflow, we observed downstream transport and dilution of high nickel concentrations.

We compared the data obtained from the lake with that from a neighbouring pond unaffected by the rock glacier. Between these two extremes, we sampled water along a gradient of rock glacier melt water impact from over 20 different water bodies including lakes, ponds and brooks, and their effluents. In these samples, we analysed trace metals together with all standard parameters like $\mathrm{pH}$, oxygen content, conductivity, major cations and anions.

In addition we took biological samples (diatoms, chironomids and other aquatic invertebrates) from the lake affected by permafrost meltwater, its outflow, and from the neighbouring pond. We observed that algae as well as animals are affected by the high metal burden. In sediment layers with high nickel and zinc concentrations, diatoms show deformations and to some extent differences in species composition. In the lake's outflow epiphyton is strongly affected, being absent in some parts; in particular in those areas where a white precipitate is observed. Aquatic invertebrates, especially the chironomid larvae and oligochaetes, accumulate metals where high loads are present (llyashuk et al. 2014).

Fish were only present in one of the studied lakes, Schwarzsee ob Sölden. In this lake, metals were accumulated in fish tissues. 


\subsection{Answers to the research questions addressed within this project}

To what extent does thawing permafrost affect water quality and aquatic organisms in alpine lakes? Do metals, especially nickel, released from permafrost accumulate in the food web and, if so, with what consequences?

We observed that metals indeed accumulate in invertebrates, and consequently in the food web, and cause deformations depending on the organism group (Ilyashuk et al. 2014). In the effluent of the lake strongly impacted by rock glacier melt water, epiphytes are missing in contrast to the un-impacted brook in its vicinity. In one of the diatom species studied in the sediment core and belonging to the genus Fragilaria, Pseudostaurosira pseudoconstruens, deformation of the valves is observed during the high nickel peaks in the early Holocene. The dominant Fragilaria species, Staurosira venter, is less abundant during the high nickel peaks in the early Holocene. Still, the total diatom assemblage is not significantly affected by the changes in the nickel content.

Over the last decades, metal accumulation in fish tissues has decreased for cadmium and lead, but slightly increased for nickel and copper which are transition metals leached together with rock glacier effluents.

Is the current release of melt water from permafrost unprecedented, or do we see comparable and repeated increases in metal concentrations during warmer periods in the past?

In the recent sediment layers of Rasass See, metals increase distinctly, especially nickel, zinc and copper. These trends differ from the increase in lead which is usually attributed to atmospheric pollution since the industrialisation, i.e. since the end of the $19^{\text {th }}$ century. In a parallel project we also investigated a sediment core from Rasass See which is covering the last 10000 years. Metal loads are highest at the beginning of the Holocene, and after the cold 8.2 kyr event, i.e. at the beginning of the Holocene warm optimum. According to our findings, metals are not released during cold periods, but seem to accumulate in the rock glacier from where they are leached upon warming.

With ongoing warming, which hazards are to be expected for downstream ecosystems and drinking water supply as compared to the historic trends?

High metal loads in the effluents gradually decrease downstream, accompanied by an increase in $\mathrm{pH}$, and a decrease in conductivity and in the concentration of most elements, especially aluminium, calcium and sulphate, pointing to Al-sulphate and gypsum precipitates, similar to that observed in acid, metal-rich effluents form mining areas (Kim and Kim 2003, España et al. 2006). Thus the impact of the rock glacier was limited to 400 to $600 \mathrm{~m}$ downstream, though still exceeding drinking water limits for nickel. 


\subsection{Summary of additional observations}

The metal content in the lake water shows strong seasonal variation, with highest metal concentrations in stagnant deep water layers. The high metal loads are dispersed in the lake during mixis when metal loads reach a maximum in the outflow. However, this impact is restricted to several hundred meters downstream when metals precipitating due to the changes in $\mathrm{pH}$ and the bicarbonate-system while $\mathrm{CO}_{2}$ is released to the atmosphere.

The short sediment core obtained in this project covered the last three millennia. We could indeed observe that the metal content increase is strongest in the topmost layers of the core. A parallel project focusing on Holocene trends of the metal burden shows that the increase is even stronger during the early Holocene; thus excluding anthropogenic atmospheric depositions as its source.

Boris Ilyashuk carried out additional studies. In a parallel project he investigated trace metal concentrations in chironomids, oligochaetes, beetles and bryophytes and compared these data to the metal load in the sediment. These organisms accumulate heavy metals, however depending on the species (e.g. beetles versus worms) and where they are dwelling in the lake (shoreline/littoral versus deep areas/profundal). 


\section{INTRODUCTION}

Glaciers are retreating worldwide, with anticipated consequences on albedo, local and global climate, water storage and risks of droughts and floods (Parry et al. 2007; Solomon et al. 2007). Much less, however, is known about permafrost and rock glaciers in alpine regions and their impact on aquatic ecosystems. While potential effects on the quantity and availability of water have been studied or can be modelled, the release of enormous quantities of nickel and other metals form thawing permafrost (Thies et al. 2007) has come as a great surprise for scientists, especially since it was generally accepted that temperate glaciers - i.e. almost all glaciers in the Alps - have little storage capacity for atmospheric depositions (Psenner and Nickus 1986).

There is, however, not only scientific interest to understand the processes behind accumulation, storage and release of metals from permafrost, but also public concern about drinking water quality. In fact, drinking water supply based on springs fed by permafrost had to be shut down in different regions of South Tyrol, Italy, because the concentrations of nickel, obviously originating from melting ice, exceeded the threshold for drinking water, i.e. $>20 \mu \mathrm{g} \mathrm{Ni} \mathrm{l}^{-1}$.

Up to now, there is no mechanism known which explains the accumulation and release of nickel in permafrost on bedrock particularly poor in nickel. If it is a natural process, depending on the weathering of nickel bearing minerals, it may have occurred several times during the Holocene as a consequence of glacial advance and retreat. If so, we expect to find signals of nickel and other metals released during historic warm periods. In contrast, if the accumulation of nickel and metal in rock glaciers depends on recent anthropogenic emissions and long-range transport, we should observe an increase in metal concentrations only in the uppermost sediment layers of alpine lakes. Here lake sediments allowed us to go back in time and trace the onset, extent and potential causes for metal increase in alpine headwaters. We investigated core profiles by carrying out a multi-proxy approach including geochemical, mineralogical, granulometric and biological analyses in order to obtain the most precise reconstruction and a comprehensive understanding of metal fluxes at high temporal resolution.

Until recently, nickel was presumed to be of low toxicity in alpine water bodies and its concentration in springs was apparently stable and low, thus causing no concern for drinking water supply (Köck 1996). Owing to high metal concentrations recently observed by Thies et al. (2007), however, part of the project focused on the impact of metal enriched melt-water from permafrost on aquatic organisms. Aquatic organisms may be directly and/or indirectly impacted by metals in water and sediments (e.g. Kiffney and Clements 1996). Direct toxic effects of metals affect diversity and 
abundance of benthic organisms (e.g. Clements et al. 2000, Ruggiu et al. 1998, Dixit et al. 1992), result in loss of sensitive species (e.g. Morin et al. 2008, Clements and Kiffney 1994), cause deformations (Reynolds and Ferrington 2001, 2002), affect growth (e.g. Cattaneo et al. 2004), and animal tissues (Köck et al. 1996, Lukin et al. 2003). Indirect effects include modifications of species interactions (e.g. Clements 1999) and reductions in food quality (e.g. Carlisle 2000).

Chironomid (Diptera, Chironomidae) larvae are excellent aquatic monitoring organisms because they live in intimate contact with sediments (Larsson 1984, Reynoldson 1987) and contaminants stored in the sediment accumulate in their tissues. As a consequence, late-instar larvae of chironomids frequently develop deformities in the mouthparts, especially the mentum (a broad, sclerotized tooth structure). Mentum deformities have been used to indicate toxic effects of copper, lead, zinc, cadmium, nickel, arsenic, and mercury in water and sediment (Janssens de Bisthoven et al. 1998, Servia et al. 1998, Mori et al. 1999, Vermeulen et al. 2000, Ilyashuk et al. 2003, Martinez et al. 2003, Swansburg et al. 2002). The frequency of deformities can be used to assess sublethal sediment toxicity of metals and other pollutants (Vermeulen 1995). We studied these deformations in contemporary chironomids and in chironomid remains from sediment samples in order to trace metal pollution and its history.

Diatoms, like chironomids, are storing information about timing and extent of metal pollution, e.g. as (i) changes in species composition, especially by the loss of sensitive species (e.g. Ruggiu et al. 1998, Dixit et al. 1991, Cunningham et al. 2005a \& b, Morin et al. 2008), and as (ii) morphological alterations, in particular as deformations and changes in the size of the valves (e.g. Cattaneo et al. 2004). Like chironomids, diatom valves were observed in modern and historic lake sediments.

Acute toxicity of many metals to freshwater fish is usually low (Köck 1996) and depends on $\mathrm{pH}$, calcium concentration, and alkalinity of the water (Alabaster and Lloyd 1980, Spry and Wiener 1991). However, chronic exposure to even low metal concentrations in the water may impact the physiology of fish and may lead to cellular damages in fish organs such as gills, liver and kidney. The target organ of nickel intoxication appears to be the liver. Hydropic degeneration (i.e. the vacuolization) of liver cells and increased levels of glutathione disulphide correlate with nickel concentrations in tissues (Hofer \& Lackner, unpubl.). Highest concentrations of $\mathrm{Ni}$ in fish are usually found in the kidney, followed by gill and liver tissues (Köck et al. 1996). The relatively high concentrations found in the gills suggest particulate matter as source for the nickel burden (Merian 1991, Merian 1991, Köck 1996, Wathne 1996). In remote high alpine lakes, elevated nickel concentrations were also detected in the bones of Arctic char (Salvelinus alpinus, Wathne et al. 1996). 
Hofer et al. (2001) observed that $\mathrm{Ni}$ affects minnows (Phoxinus phoxinus) in alpine lakes, but the authors were, at that time, unaware of thawing permafrost as a potential source for elevated concentrations of nickel and other metals. However, melt water from permafrost may affect the bioavailability of metals and consequently the metal uptake and toxicity in fish. In this study, we had access to analyses of fish tissues collected over the last 15 years which were than compared to fresh fish tissues obtained within this project, thus allowing us to investigate whether the metal (esp. Ni and $\mathrm{Hg}$ ) burden has increased or decreased over time. The trends in metal accumulation in fish were then compared with the results from the study of biological indicators in dated sediment layers. 


\section{SAMPLING SITES AND METHODS}

\subsection{Study sites}

We focused on three high alpine lakes (Figure 1; Table 1); one with a tremendous nickel increase over the last decade (Rasass See, $2682 \mathrm{~m}$ a.s.l.); one less affected by rock glaciers (Schwarzsee ob Sölden, 2796 m a.s.l.); and one without direct influence of a rock glacier in its catchment (Oberer Saldursee, $2923 \mathrm{~m}$ a.s.l.). The catchment area of RAS is $0.22 \mathrm{~km}^{2}$ with $0.038 \mathrm{~km}^{2}$ permafrost, that of SOS is $0.18 \mathrm{~km}^{2}$ with $0.012 \mathrm{~km}^{2}$ permafrost (see Thies et al. 2007), while SAL $\left(0.08 \mathrm{~km}^{2}\right.$ ) has no active permafrost in its catchment. The catchment areas of these lakes are mainly composed of granitic gneisses and micaschist, with considerable amounts of arseno-pyrites at SOS and SAL. The soil cover of all catchment areas is sparse with only scarce vegetation which is slightly better developed on the northern slopes of Rasass See (see cover picture). A large proportion of each catchment consists of bare rocks. Snow accounts for most of the annual precipitation, though wet precipitation started to dominate in summer since the eighties. During cold periods large amounts of the catchment area are covered by perennial snow fields.

In addition, we obtained sediment cores and aquatic organisms from the lake with the highest impact of melting permafrost and compared them to sediment analyses form the lake with the low impact, Schwarzsee ob Sölden, where we also investigated the metal content in fish. No fish were living in the other two lakes which prevented a direct comparison. Within a joined project (PI Boris Ilyashuk), metals were also analysed in aquatic insects of a pond located next to Rasass See but which is unaffected by rock glacier melt water.

We also sampled the effluents and ponds in the catchment of the three main study sites and further lakes in the vicinity, all located on crystalline basins and above timberline (around $2300 \mathrm{~m}$ a.s.l. in this region, Nicolussi et al. 2005 and pers. comm.). In total, 25 different water bodies have been sampled for limnochemistry and metal analyses along an altitudinal gradient ranging from 2483 to $3218 \mathrm{~m}$ a.s.l. including 10 lakes, 8 ponds, 5 inflows and 2 outflows, and one additional spring snow sample. 


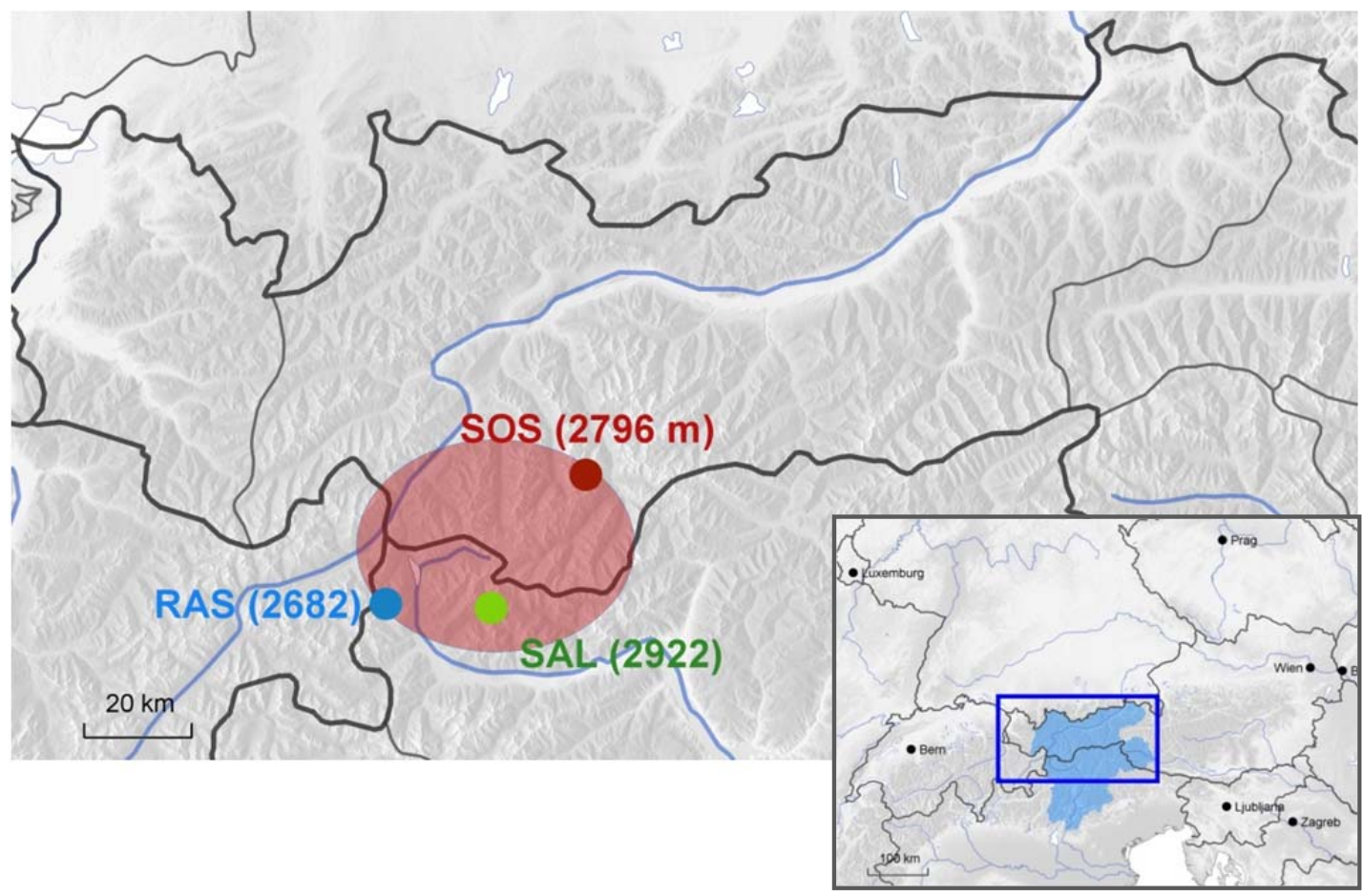

Figure 1 Location of the study sites RAS = Rasass See; SAL= Saldur See; SOS = Schwarzsee ob Sölden in North Tyrol (Austria) and South Tyrol (Italy).

Table 1 Geographic and morphometric characteristics of the studied water bodies

\begin{tabular}{|c|c|c|c|}
\hline & RAS & SOS & SAL \\
\hline Location & $\begin{array}{l}\text { Ötztaler Alps, } \\
\text { South Tyrol, Italy }\end{array}$ & $\begin{array}{l}\text { Ötztaler Alps, } \\
\text { North Tyrol, Austria }\end{array}$ & $\begin{array}{l}\text { Ötztaler Alps, } \\
\text { South Tyrol, Italy }\end{array}$ \\
\hline Latitude (N) & $46^{\circ} 44^{\prime} 50^{\prime \prime}$ & $46^{\circ} 57^{\prime} 57^{\prime \prime}$ & $46^{\circ} 45^{\prime} 24^{\prime \prime}$ \\
\hline Longitude (E) & $10^{\circ} 27^{\prime} 23^{\prime \prime}$ & $10^{\circ} 56^{\prime} 46^{\prime \prime}$ & $10^{\circ} 43^{\prime} 17^{\prime \prime}$ \\
\hline Altitude ( $m$ a.s.I.) & 2682 & 2796 & 2922 \\
\hline Surface area $\left(\mathrm{km}^{2}\right)$ & 0.015 & 0.035 & 0.006 \\
\hline Catchment area $\left(\mathrm{km}^{2}\right)$ & 0.22 & 0.18 & 0.08 \\
\hline Max depth, m & 9 & 18 & 9 \\
\hline
\end{tabular}

\subsection{Water analyses}

Water samples were obtained along a vertical profile at the deepest point of each lake, from any inflows or outflows of the lakes, and any nearby springs or water bodies. SOS and SAL were sampled during autumn overturn. RAS was sampled more frequently including profiles under ice, after ice out, in mid-summer, and in late autumn. We used an UWITEC water sampler for collecting water in $2 \mathrm{~m}$ intervals at the surface, in 2, 4, 6 and $8 \mathrm{~m}$ depth, after measuring high resolution profiles of oxygen, temperature, $\mathrm{pH}$, and conductivity using a YSI multi probe (YSI 6920 or 6600V2). We additionally measured pH (Orion930, Orion Ross-Electrode), alkalinity (titration), and conductivity 
(WTW - LF 196, Tetracon 96) in the water samples in the lab at $25^{\circ} \mathrm{C}$. Major ions and cations were determined by ion chromatography (Dionex ICS - 1100 IC). Dissolved organic carbon and total nitrogen were measured with a total organic carbon analyser (Shimadzu TOC - V CPH). Ammonium $\left(\mathrm{NH}_{4}\right)$, total (TP) and dissolved reactive phosphorus (DRP), and dissolved reactive silica (DRSi) was measured chromatographically following Wagner 1969, Vogler 1965, and Smith and Milne 1981. Metals in the water column were determined by ICP-OES.

\subsection{Living aquatic organisms}

Living aquatic organism were sampled by kick net sampling, dredging and with an Ekman grab (chironomids, worms), by collecting bugs along the shore line, and by scrubbing stones with a brush (diatoms). The aquatic organisms have been screened for deformations (diatoms and chironomids), and metal contents have been analysed in dried and ground animal tissues (invertebrates) using XRFA.

From the fish bearing lake, SOS, we collected arctic char (Salvinus alpinus) in September 2010 using gill nets of $20 \mathrm{~mm}$ mesh size. Liver and kidney were subsampled and acid-digested in a highpressure microwave oven. Metals (Cadmium Cd, Copper Cu, Lead Pb, Nickel Ni, Zinc Zn) were analysed by ICP-OES. Analyses were performed by the Institute of Mineralogy and Petrography at University of Innsbruck with DOLT-2 from the National Research Council of Canada as reference material. Liver subsamples from 2007 were analysed for total mercury at Environment Canada's Aquatic Contaminants Research Division in Burlington (Canada). Liver subsamples from 2011 were analysed for total mercury by the Austrian Agency for Health and Food Safety (AGES).

\subsection{Sediment cores}

Short sediment cores were obtained with a modified Kajak sampler (UWITEC gravity corer, www.uwitec.at) in July 2010. One master core and several backup cores were taken in the deepest part of the lake. The cores were directly extruded (vertically) at the lake shore. The outer margins of the core were not used for analyses in order to avoid smearing and contamination. In order to allow for a high time resolution, the cores were subdivided in $0.25 \mathrm{~cm}$ steps in the top $10 \mathrm{~cm}$ of the core, and in $0.5 \mathrm{~cm}$ steps below $10 \mathrm{~cm}$. The subsamples were then stored at $4{ }^{\circ} \mathrm{C}$ until analyses. Several analyses were carried out on the same subsample material after drying (bulky density and dry weight) and grinding (geochemistry, dating, $\mathrm{CN}$ ). In addition, diatom and chironomid analyses were carried out on fresh material in each sampling horizon. Within a parallel project ("Nickel Control"), we 
obtained long sediment cores in August 2011. These long cores go back to the onset of the lake over 10000 years ago. These cores were up to two meter long and subsampled in continuous $1 \mathrm{~cm}$ layers down to the layers which consisted basically of glacial silt, and courser, chiefly inorganic, material (sand, stones).

\subsection{Diatoms in the sediment core}

Diatoms were investigated from sediment cores and from samples obtained in littoral zones and in inflows and outflows. Diatoms were prepared following standard preparation techniques (digestion in $\mathrm{HCl}$ and $\mathrm{H}_{2} \mathrm{O}_{2}$, see Battarbee et al. 2001) and mounted in Naphrax. A minimum of 300 diatom valves were identified in continuous samples and enumerated in every sample. Deformations of diatom valves were recorded during counting. Major shifts in species composition were observed by indices (Hills N2), multivariate statistics (DCA axes scores), and crosschecked visually within the diatom stratigraphies and then compared to changes in metal concentrations. Diatom inferred $\mathrm{pH}$ is based on an extended version of the "Alps" dataset by Marchetto and Schmidt (1993).

\subsection{Chironomids in the sediment core}

For chironomid analyses, wet sediment samples were sorted in a Bogorov counting tray under a dissecting microscope at 25-40× magnification (Walker 2001). Chironomid remains were picked out with a pipette, dehydrated in 100\% ethanol and slide-mounted ventral side up in Euparal for taxonomic identification. For species composition, at least 100 chironomid head capsules were counted and identified from each sample (Heiri and Lotter 2001). Chironomid identification was mainly based on Andersen et al. (2013) and Brooks et al. (2007).

\subsection{Physical and geochemical methods}

Dating of recent sediments (i.e. last $100-150 \mathrm{yrs}$ ) is based on ${ }^{210} \mathrm{~Pb},{ }^{226} \mathrm{Ra}$, and ${ }^{137} \mathrm{Cs}$ trends in bulk sediments (Peter Appleby, University of Liverpool). Dating of older core sections is based on ${ }^{14} \mathrm{C}$ AMS analyses of plant macrofossils (Poznan Radiocarbon Laboratory or Beta Analytics).

Selected major and trace elements were analysed with an EDXRFA (Spectro / XEPOS Plus). Of each sample, about $0.5 \mathrm{~g}$ dried sediment was measured directly after drying $\left(55^{\circ} \mathrm{C}\right)$ and milling (agate ball mill) in Chemplex-SpectroMicroCups 3110. The method is non-destructive, fast, and 
quantitative; and interference with dissolution liquids is avoided. Analyses of standard reference materials (Geo - Standard Reference Materials, Lucas-Tooth-Modell) validated the results.

CNS was determined by a CNS Analyser (Carlo Erba). For comparison, LOI was analysed in selected samples after muffling at $550^{\circ} \mathrm{C}$.

\subsection{Data handling and statistics}

For the geochemical data, $\mathrm{Zr}$ or Ti were used for normalization because they are largely insoluble, immobile, and weathering-resistant elements that are not utilized by organisms and have no significant anthropogenic sources. For trace metals (especially $\mathrm{Ni}, \mathrm{As}, \mathrm{Pb}, \mathrm{Zn}$ ), the normalized stratigraphies help to separate natural, lithogenic variations from atmospheric and anthropogenic inputs. For the other elements, deviations in normalized values indicate variations in mineral composition. The geochemical data were also compared to grain size and mineral profiles. Enrichment factors were not calculated due to the huge natural variability in the sediment with the largest change occurring during the first two millennia of the lake's existence.

Classical (STATISTICA, EXEL) and multivariate statistics (CANOCO 5) were used to observe significant synchronicities in the variation in metals, trace elements, grain size and minerals (e.g. PCA); major shifts in the composition of biological data (e.g. DCA, PCA) to depict major changes in species composition; synchronicities in changes in geochemical and physical data as compared to the aquatic organisms (diatoms, chironomids) (e.g. CCA, RDA), thus testing the influence of metals on aquatic organisms. Constrained Cluster analyses (ZONE) were used to define boundaries independently for each group of stratigraphic data (i.e., diatoms, geochemistry + grain size + mineralogy, etc.). 


\section{Results AND Discussion}

\subsection{Seasonal variations of basic limnochemical parameters in Rasass See}

The limnochemistry of lake Rasass follows a seasonal pattern with a strong stratification under ice cover characterized by an increase in conductivity from $30 \mu \mathrm{S} / \mathrm{cm}$ in the top to $1770 \mu \mathrm{S} / \mathrm{cm}$ in the bottom layers, accompanied by a decrease in $\mathrm{pH}$ and oxygen (see Figure 2). The ice cover, and thus the stratification, currently lasts from late October/early November to late June/early July. After ice out it takes some time to break the chemocline. Gradually the lake is mixing down to the deeper water layers (Figure 3). The lake is facultative meromictic but can be polymictic once the whole water column starts to mix (e.g. in 2012).

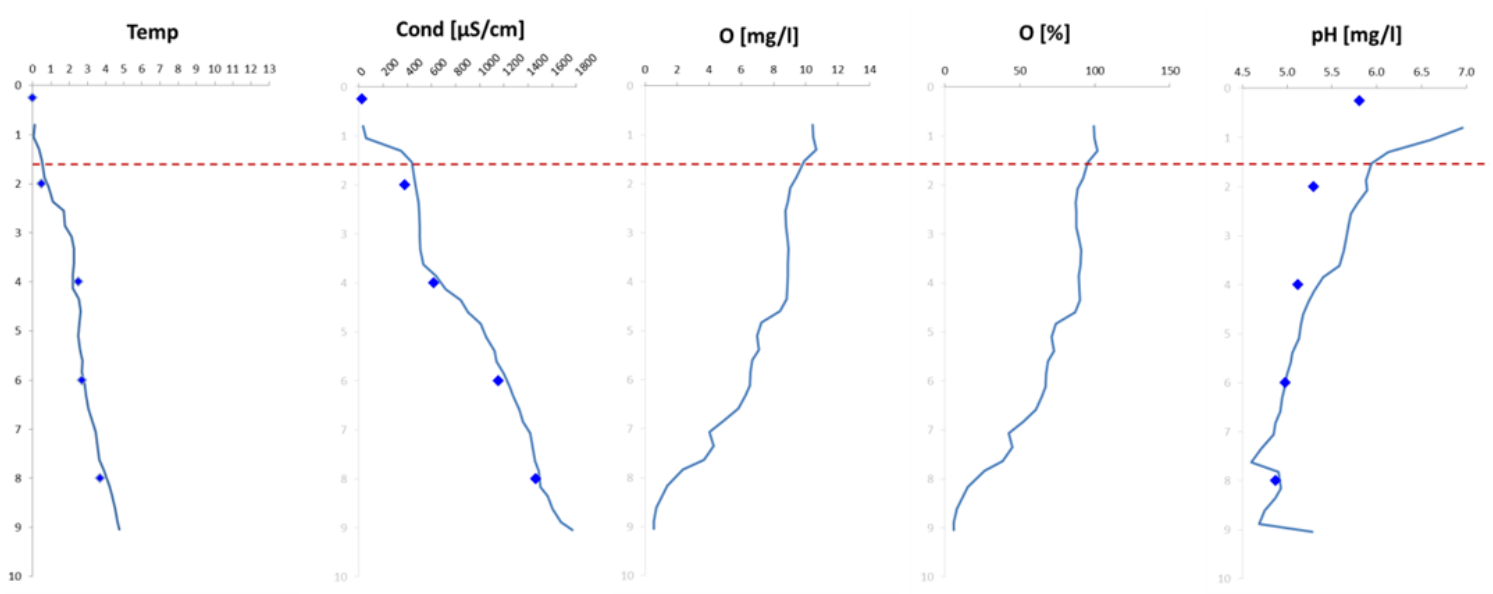

Figure 2 Strong stratification on $26^{\text {th }}$ June 2013 under a winter cover consisting of $20 \mathrm{~cm}$ snow and $80 \mathrm{~cm}$ ice. Note the strong increase in conductivity from the topmost layer to the bottom. Lines are profiles measured with a mulitprobe in situ. Diamonds are measurements in unfiltered water samples at $25^{\circ} \mathrm{C}$ ambient temperature in the lab.

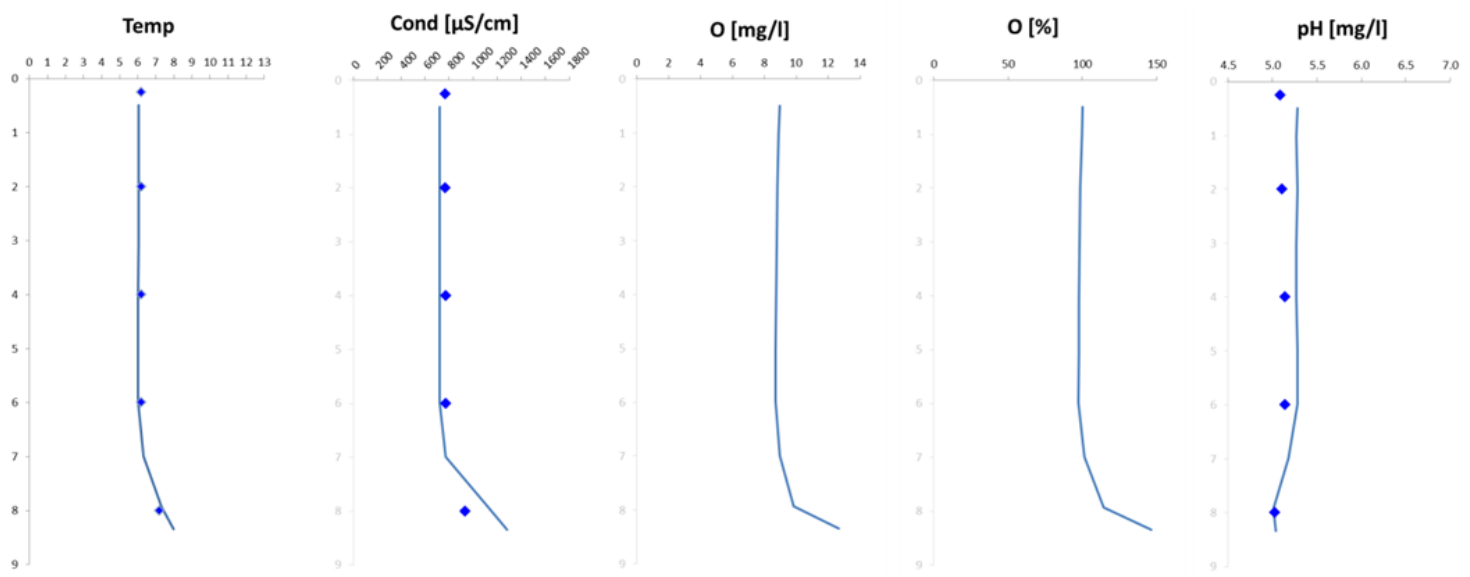

Figure 3 Mixis down to $7 \mathrm{~m}$ on $9^{\text {th }}$ Oct. 2013 (no ice cover). Diamonds are measurements in unfiltered water samples at $21^{\circ} \mathrm{C}$ ambient temperature in the lab. The lake was mixing completely in 2010, 2011 and 2012, but not in 2013 or 2014. (Note that the lowermost position of the probes is $15 \mathrm{~cm}$ distant from the sediment.) 


\subsection{Nickel variation in water samples from Rasass See}

In Lake Rasass, nickel concentrations varied between 0.006 and $1.059 \mathrm{mg} / \mathrm{l}$ in the freshwater samples obtained between July 2010 and August 2014. The huge variation is driven by changes in the $\mathrm{pH}$ and redox conditions, and reflects different mixing patterns. We measured the highest nickel concentrations in the stratified water column in $8 \mathrm{~m}$ depth in August 2014. The lowest nickel concentrations were measured in the surface water samples after ice break when the top water layers were diluted by snow meltwater. Generally low nickel concentrations were measured in the surface layers during and shortly after ice break each year.

Nickel concentrations in the water column are strongly related to changes in conductivity $\left(\mathrm{R}^{2}=0.98, \mathrm{p}<0.001\right)$, sulphate $\left(\left[\mathrm{SO}_{4}\right]^{2-},\left(\mathrm{R}^{2}=0.98, \mathrm{p}<0.001\right)\right.$ and $\mathrm{H}^{+}\left(\mathrm{R}^{2}=0.88, \mathrm{p}<0.001\right)$, (Figure 4) which all demonstrate a distinct seasonal variation (see Figure 2 and Figure 3 for conductivity and $\mathrm{pH}$ ). Thus the nickel concentrations are highest during periods of high sulphate concentrations when conductivity is high. The increase in sulphate is counterbalanced by an increase in hydrogen ions $\left(\mathrm{H}^{+}\right.$,i.e. a decrease in $\left.\mathrm{pH}\right)$. Together with nickel also zinc, cobalt, and copper concentrations are increasing in the lake water samples, as well as the cations calcium (Ca), magnesium $(\mathrm{Mg})$, potassium $(\mathrm{K})$, and sodium $(\mathrm{Na})$ and silicon $(\mathrm{Si})$, aluminium $(\mathrm{Al})$, and manganese (Mn). The correlation with these parameters is also illustrated in the PCA of the chemical parameters of Rasass See (Figure 5). PCA axis one reflects the increase in solute contents in the water which is most likely driven by weathering of the rock glacier. PCA axis two reflects the changes in the redox conditions, especially during mixis and stratification.
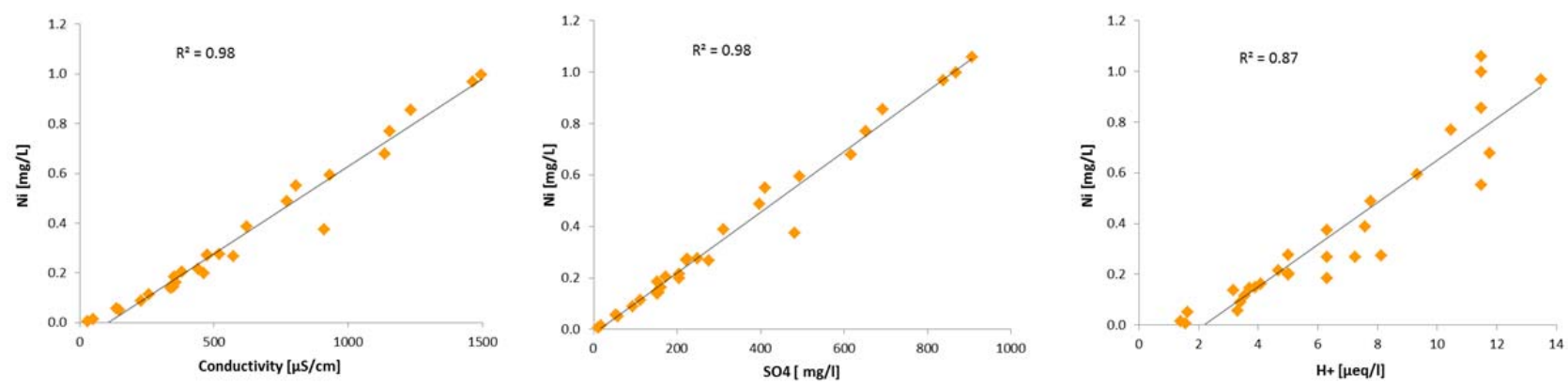

Figure 4 Linear Regressions of nickel versus conductivity, sulphate, and hydron in 30 water samples obtained from Rasass See between July 2010 and October 2014. Conductivity, sulphate $\left[\mathrm{SO}_{4}\right]^{2-}$ and hydron $\mathrm{H}^{+}$variations significantly explain trends in nickel. 


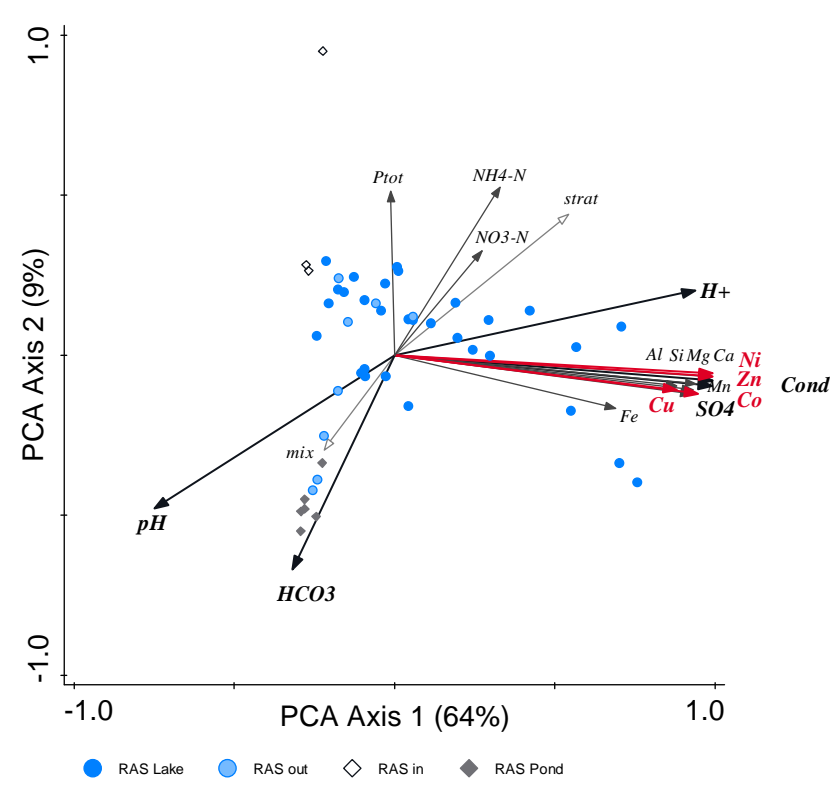

Figure 5 PCA of water samples collected from Rasass See and its outflow, its temporary surface inflows (only present during snowmelt), and the pond located next to Rasass See. Note the close position of all transition metals with both sulphate $\left[\mathrm{SO}_{4}\right]^{2-}$ and hydron $\mathrm{H}^{+}$, the cations $(\mathrm{Ca}, \mathrm{K}, \mathrm{Mg}, \mathrm{Na}$,$) and \mathrm{Al}$ and $\mathrm{Si}$. PCA axis 1 reflects increase in solute content. PCA axis 2 change in redox conditions.

\subsection{Nickel variation in water samples of 25 different water bodies}

Metal variation in 25 different water bodies, with and without rock glacier influence, sampled along an altitudinal gradient, depicted the same correlations with conductivity $\left(\mathrm{R}^{2}=0.98, \mathrm{p}<0.001\right)$ and sulphate $\left(\mathrm{R}^{2}=0.98, \mathrm{p}<0.001\right.$, Figure 6) as in Rasass See. The relationship to hydron was the same when the lakes located above $3000 \mathrm{~m}$ were excluded $\left(\mathrm{R}^{2}=0.87, \mathrm{p}<0.001\right.$. Figure 6$)$ but not when all samples were taken into account $\left(\mathrm{R}^{2}=0.20\right)$. Thus the pattern observed in Rasass See is not exceptional, although the metal concentrations of $\mathrm{Ni}, \mathrm{Cu}, \mathrm{Co}$ and $\mathrm{Zn}$ were highest in that lake.
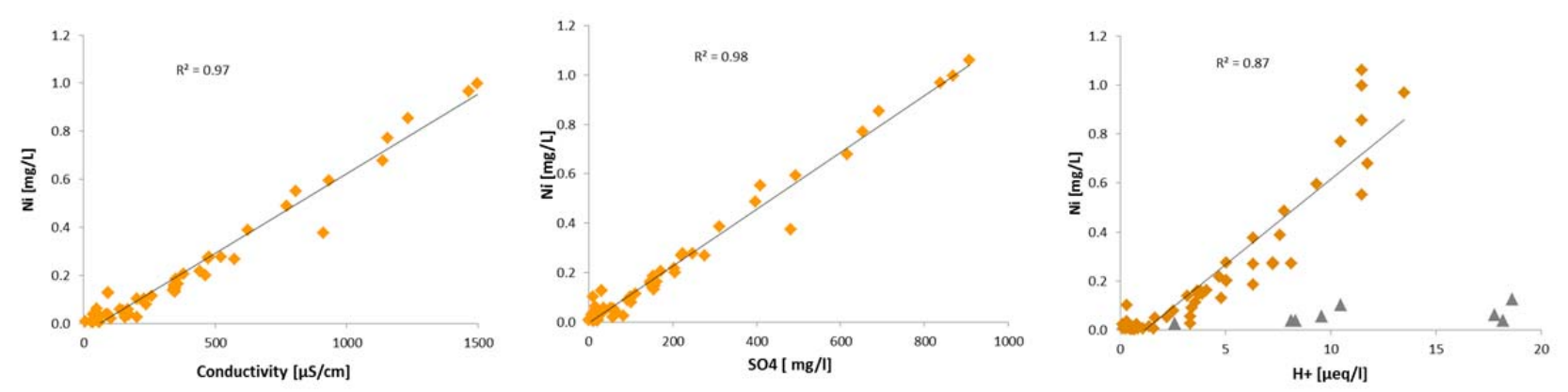

Figure 6 Linear Regressions of nickel versus conductivity, sulphate, and hydron in 98 water samples obtained from high alpine lakes and ponds and their effluents between July 2010 and October 2014. Conductivity, sulphate $\left[\mathrm{SO}_{4}\right]^{2-}$ and hydron $\mathrm{H}^{+}$variations significantly explain trends in nickel. Note that for nickel versus hydrogen concentrations, samples from ponds located above $3000 \mathrm{~m}$ (grey triangles) were excluded from the regression ( $R^{2}$ for all samples was distinctly smaller with 0.20 ). 
This is also confirmed when all samples obtained from different water bodies are depicted in a PCA (Figure 7) which is very similar to the PCA carried out of the RAS samples alone. The relationship of nickel (and zinc and cobalt) to conductivity and sulphate remains the same, while hydron is having less influence on nickel but is now closer related to changes in copper and iron. However, when the water bodies above $3000 \mathrm{~m}$ are excluded, the PCA is very similar to the one for the Rasass See alone (Figure 5). This is also the case when all Rasass See samples are excluded (Figure 8). This is pointing to a common influence of $\mathrm{pH}$ and conductivity on the metals observed in the water bodies independent of the presence of rock glaciers in the catchment. However, the metal concentrations are highest in the lakes with active rock glaciers in their catchment, esp. Rasass and Portless See.

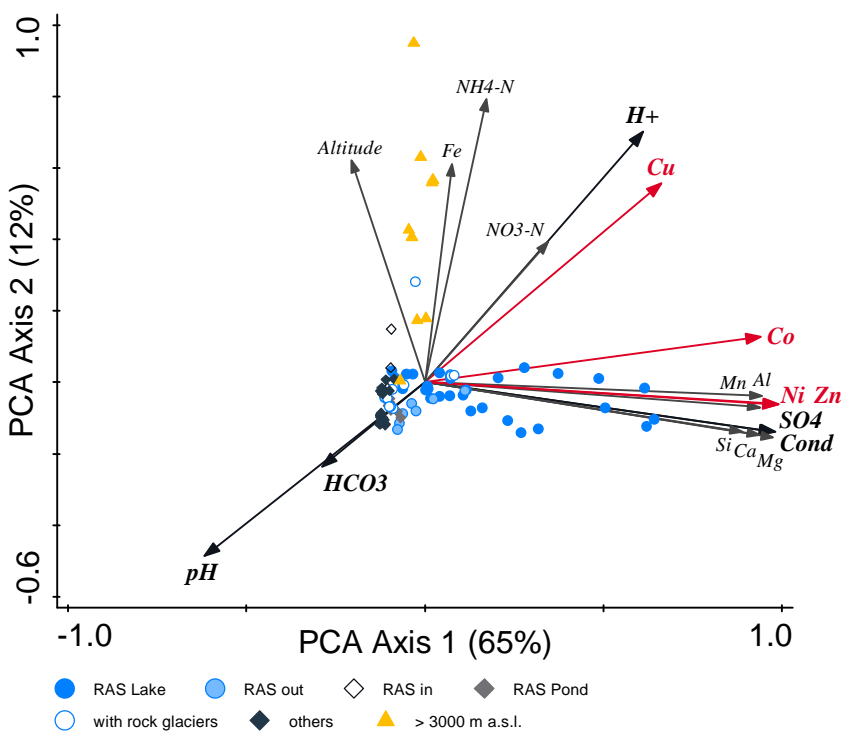

Figure 7 PCA of limnochemical parameters observed in 25 different water bodies (98 samples). Note the different location of hydron $\left(\mathrm{H}^{+}\right)$and copper $(\mathrm{Cu})$ when including lakes located above $3000 \mathrm{~m}$.

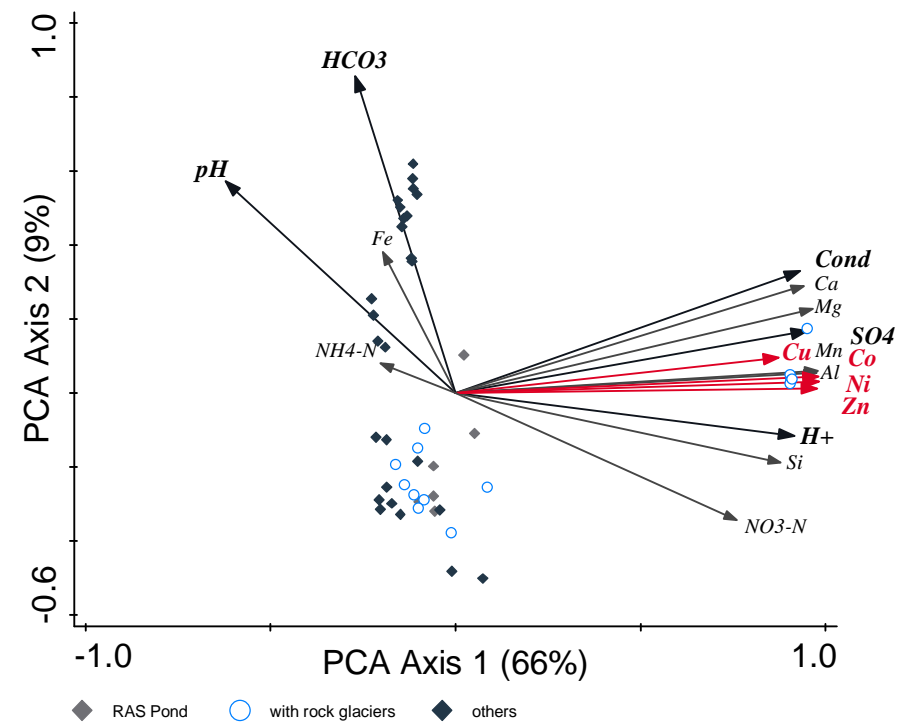

Figure 8 PCA of limnochemical parameters observed in 17 different water bodies (49 samples, Rasass See and lakes above $3000 \mathrm{~m}$ a.s.l. excluded). Note that the PCA is very similar to Figure 5 but rotated around the $x$ axes. 


\subsection{Nickel variation in the sediment of Rasass See}

Nickel concentrations in the sediment core of Rasass See are high, with an average of $231 \mu \mathrm{g} \mathrm{Ni} / \mathrm{g} \mathrm{DW}$ (dried sediment) and a median of $185 \mu \mathrm{g} \mathrm{Ni}$ g DW. The highest nickel concentrations of $576 \mu \mathrm{g} \mathrm{Ni} / \mathrm{g}$ DW are observed between 7600 and $7850 \mathrm{cal}$. yr. BP, but nickel loads were also high between 9500 and $8700 \mathrm{cal}$. yr. BP (Figure 9, top). Thus nickel load was highest during the early Holocene and was always above the average crustal values that are ranging between 18 and $60 \mu \mathrm{g} \mathrm{Ni} / g$ DW (EarthRef.org, database GERM (Geological Earth Reference Model)), or are suggested to be $47 \pm 11 \mu \mathrm{g} \mathrm{Ni}$ g according to Rudnick and Gao (2014). We therefore did not use enrichment factors in our graphs as neither the crustal values nor the early Holocene can be used as a reference. When using the $\mathrm{Zr}$ ratios as a correction, the trends remain largely unchanged (Figure 11).

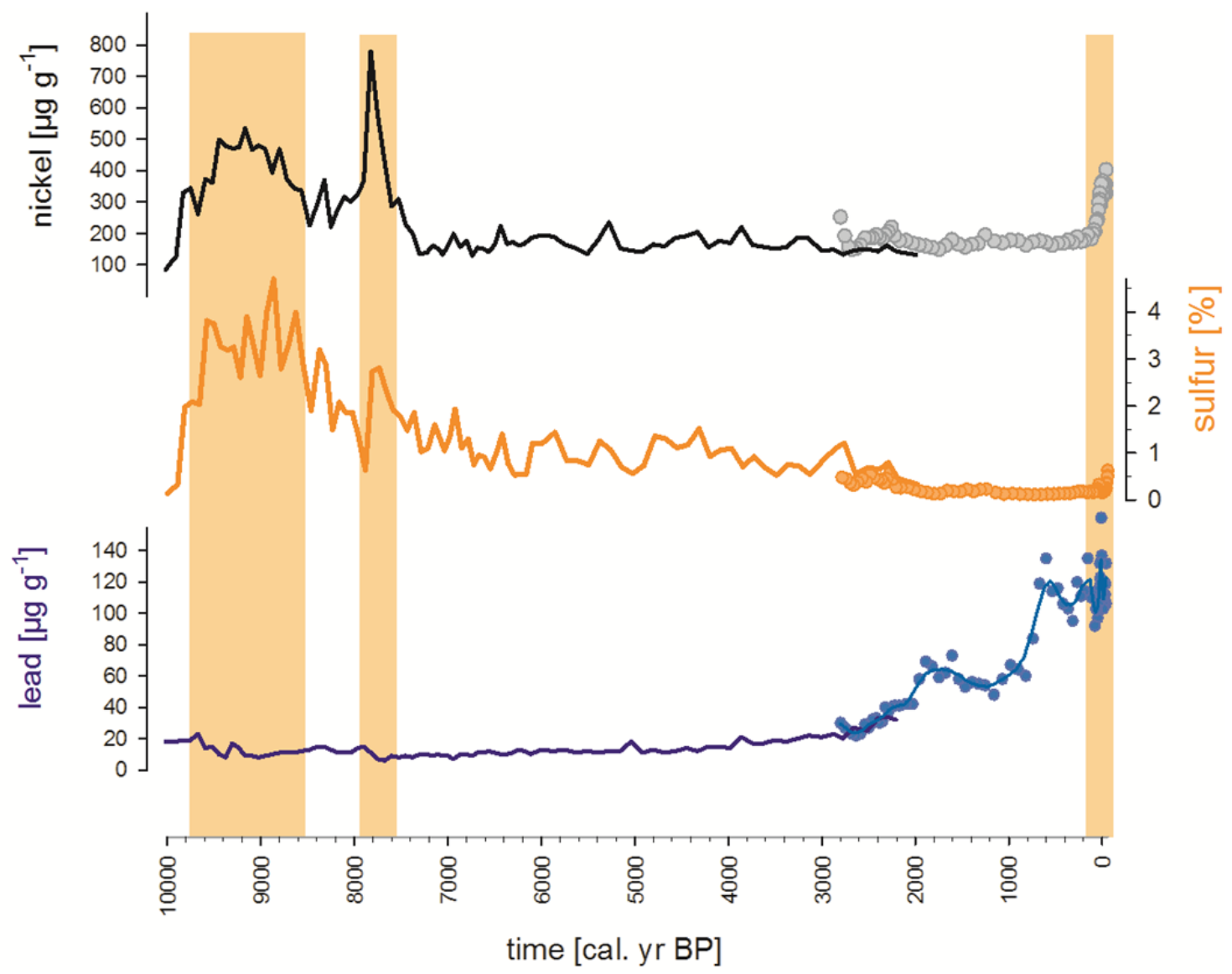

Figure 9 Trends of nickel, sulfur, and lead in the sediment of Rasass See (combined stratigraphies of cores RAS10-K1 and RAS11-P1. Note that lead which is typically influenced by atmospheric deposition shows a distinct increase in the top core section. In contrast, nickel concentrations are highest in the early Holocene together with sulfur.

Nickel trends follows the sulfur concentrations in the sediment (Figure 9, $\mathrm{R}^{2}=0.66$ within core P1) thus depicting the same correlation we observed in the water column (Figure 4 and Figure 6). In the principal component analyses (PCA) of the geochemical parameters measured in the sediment core, nickel is grouped together with sulfur, zinc, iron, and copper (Figure 10). 

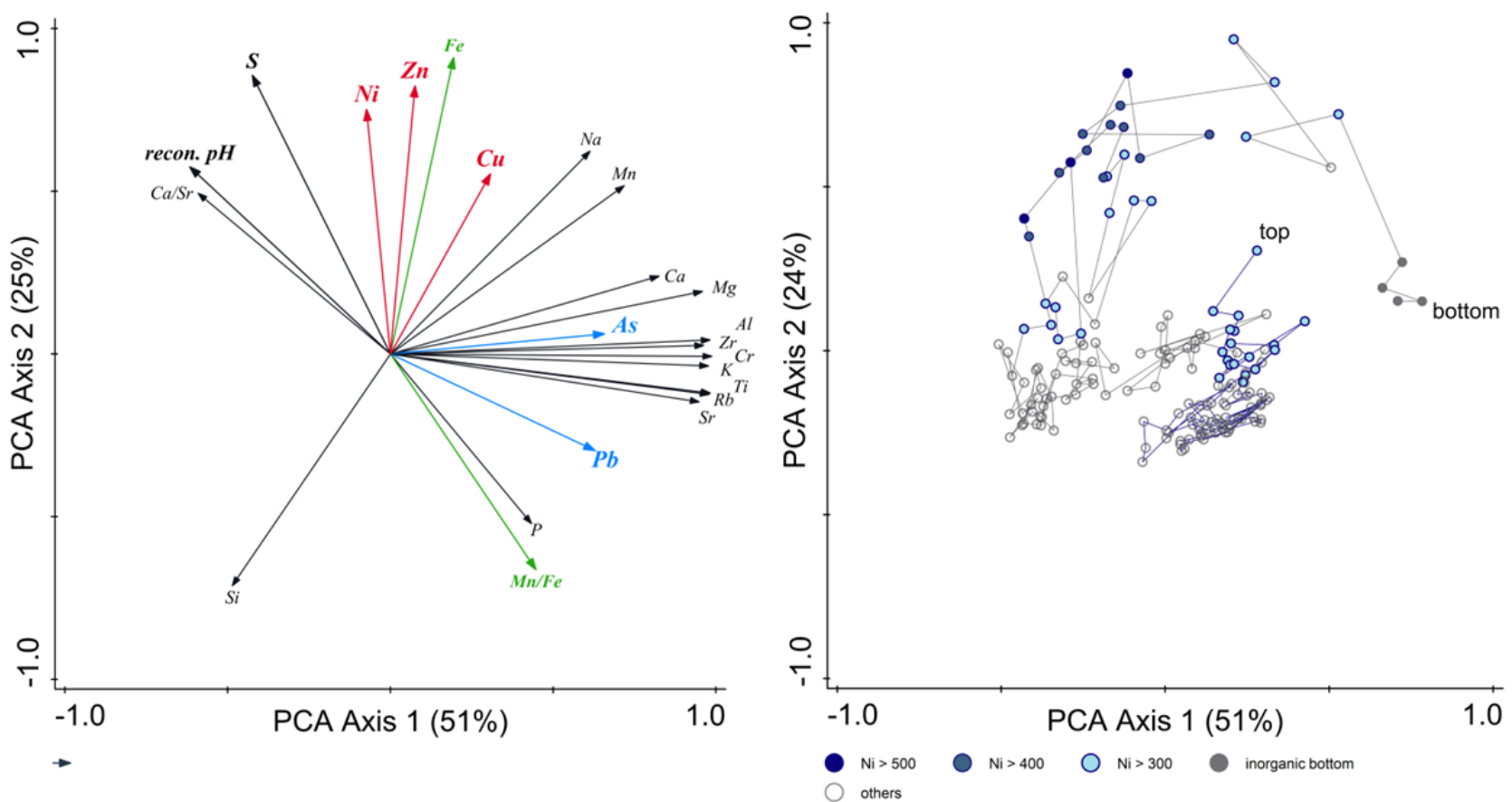

Figure 10 Principal component analyses of geochemical parameters in the sediment cores RAS10-K1 and RAS11-P1. Left: position of variables, right: position of sediment samples coloured according to the nickel amount observed in the sediment layers. Note that the different positioning of the top high nickel concentrations are due to the increase in lead in the upper sediment layers.

Thus nickel, zinc, and to a lesser extent iron and copper, are generally increasing when sulfur is increasing (see also Figure 11). The relationship to $\mathrm{pH}$ is more complex: while both $\mathrm{pH}$ and nickel were relatively high before 8200 cal. yr BP, pH gradually declined after that period. Nickel had its maximum between 7600 and 7850 cal. yr. BP when pH was already lower. After this nickel peak, nickel was relatively stable at a low concentration while $\mathrm{pH}$ kept decreasing. Of course, $\mathrm{pH}$ reconstructed from diatoms need not reflect the $\mathrm{pH}$ in the sediment itself which is usually strongly changing in the sediment water interface and just below. Nickel is strongest correlated to zinc in both cores, while the correlation with sulfur is higher in the lower core (RAS11-P1). This is also due to diagenetic processes occurring within and several centimetres below the sediment water interface which strongly affect sulfur and iron concentrations in core RAS11-K1. Taking into account the mineralogical composition of the long core RAS11-P1 (not available for the short core), nickel is strongest correlated with pyrite $\left(\mathrm{FeS}_{2}, \mathrm{R}^{2}=0.42\right)$.

When nickel increase was first observed in the water column, it was assumed that it might origin form atmospheric depositions. Atmospheric deposition leaves distinct traces in sediment layers. Most typically, lead and arsenic increase in the recent centuries and lead might even show peaks during the Roman period. We also observed a distinct increase in lead (and, to a lesser extent, arsenic) in the upper sediment layers of Rasass See. This is, however, occurring earlier, and by a much higher factor than for nickel (sees Figure 9 and Figure 11). In any case, atmospheric depositions cannot explain the high nickel and zinc peaks in the early Holocene. 


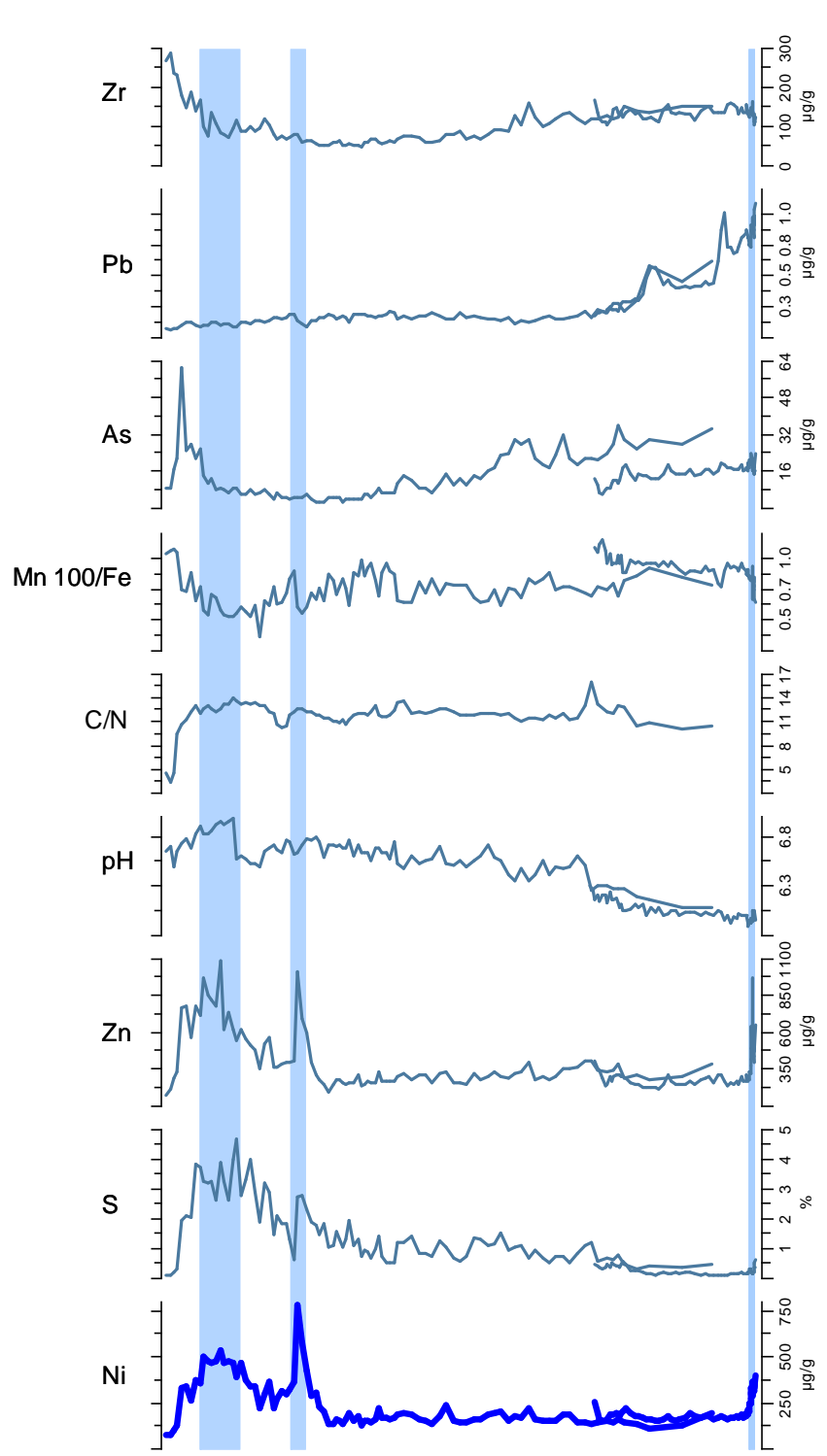

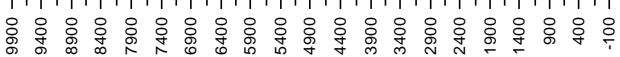

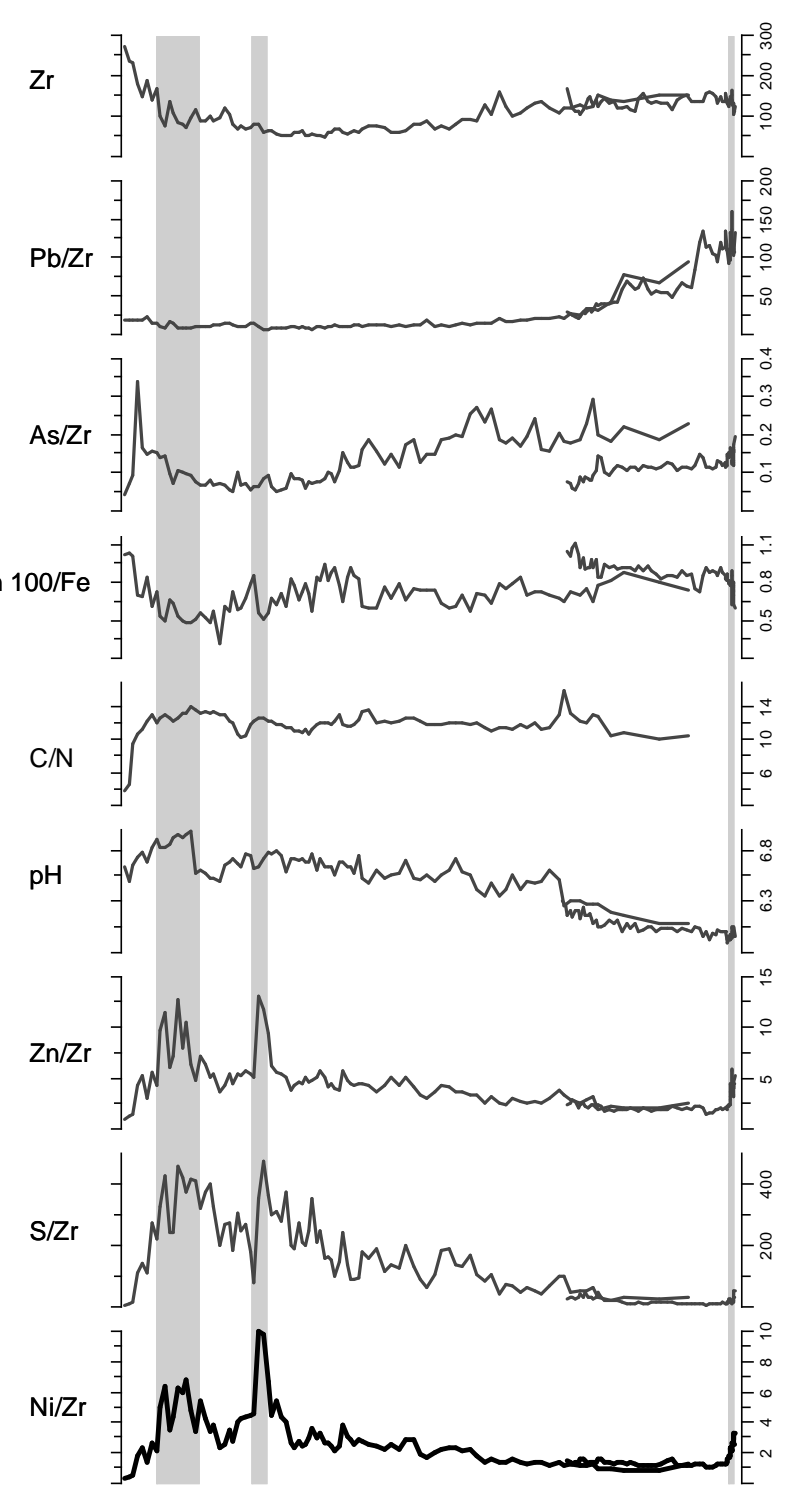

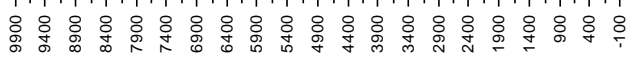

Time (cal. yr BP)

Figure 11 Selected geochemical parameters measured in the sediment, including manganese to iron ratios which are often decreasing with oxygen; carbon to nitrogen ratio as indicator for terrestrial versus in lake organic matter; and diatom inferred $\mathrm{pH}$ as indicator for the $\mathrm{pH}$ changes in the water column. Left: raw concentrations, right: elemental trends normalized by zircon. Note that there is no major difference between the raw and normalized trends of nickel, zinc, arsenic or lead.

As the nickel peaks are linked to sulfur dynamics, weathering processes, accompanied by redox and $\mathrm{pH}$ shifts, are the most likely reason for increase in nickel and zinc as changes in redox and $\mathrm{pH}$ cause desorption or dissolution of nickel bearing particles. We attribute this to the melting of the permafrost which started after the deglaciation of the catchment area, was then briefly interrupted during the cold $8.2 \mathrm{kyr}$ event which afterwards resulted in a further nickel spike when temperature increased after $8000 \mathrm{cal}$ yr. BP. We assume that when nickel levels off around $7000 \mathrm{cal}$ yr. BP, the rock glacier has either become ice free, thus becoming a fossil rock glacier, or that it has at least stabilized due to the warm and humid conditions 
during this period. Over the last decades, the pronounced recent warming which followed the relatively cold "Little Ice Age" during which glaciers grew in the Alps, triggered another melting process of the rock glaciers and thus another increase in the metal load. According to our findings, metals are not released during cold periods, but seem to accumulate in the rock glacier from where they are leached upon warming. 


\subsection{Effects on diatoms}

We observed 201 different diatom taxa in the sediment cores from Rasass See, with 91 taxa accounting for more than $1 \%$ in at least one sediment layer, and occurring at least 5 times in the whole stratigraphy. The most abundant groups are small Fragilariaceae (Staurosira or Psendostaurosira), Achnanthaceae (Psammothidium spp.), Pinnularia or Aulacoseira taxa. Typically for lakes with low pH, Cyclotella taxa are absent.

There is a distinct change in diatom species composition with a complete shift in diatom taxa from the bottom to top (Figure 12). In the oldest layers we observed a strong dominance of Staurosira venter (over 70\%) or Pseudostaurosira pseudoconstruens (up to 50\%), respectively. Some taxa, like Encyonema silesiacum and Brachysira neoexilis mainly occur in this section. Around $9400 \mathrm{cal}$. yr BP there is a rapid shift, with the abundance of Staurosira venter decreasing to ca. 11\% (between 9330 and 8900), and an increase in Pseudostaurosira pseudoconstruens (50\%) followed by an increase in Psendostaurosira brevistriata (40\%). Around 8500 cal. yr BP, Staurosira venter once more dominates, reaching $85 \%$ relative abundance, and at the same time causing the strongest depletion in species diversity (Figure 12 and Figure 13). Around 8000, Staurosira venter becomes gradually less abundant, reaching a minimum around $7800 \mathrm{cal}$. yr BP. This is concurrent with an increase in the Hills N2 diversity index (Figure 13) and is reflected in the presence of several species without an overruling dominance of any single taxon between $8000 \mathrm{cal}$. yr BP and $2200 \mathrm{cal}$. yr BP. After 2200 the dominant taxa are Psammothidium curtissimum and Aulacoseira distans var. nivaloides which have been largely absent in the old core sections.

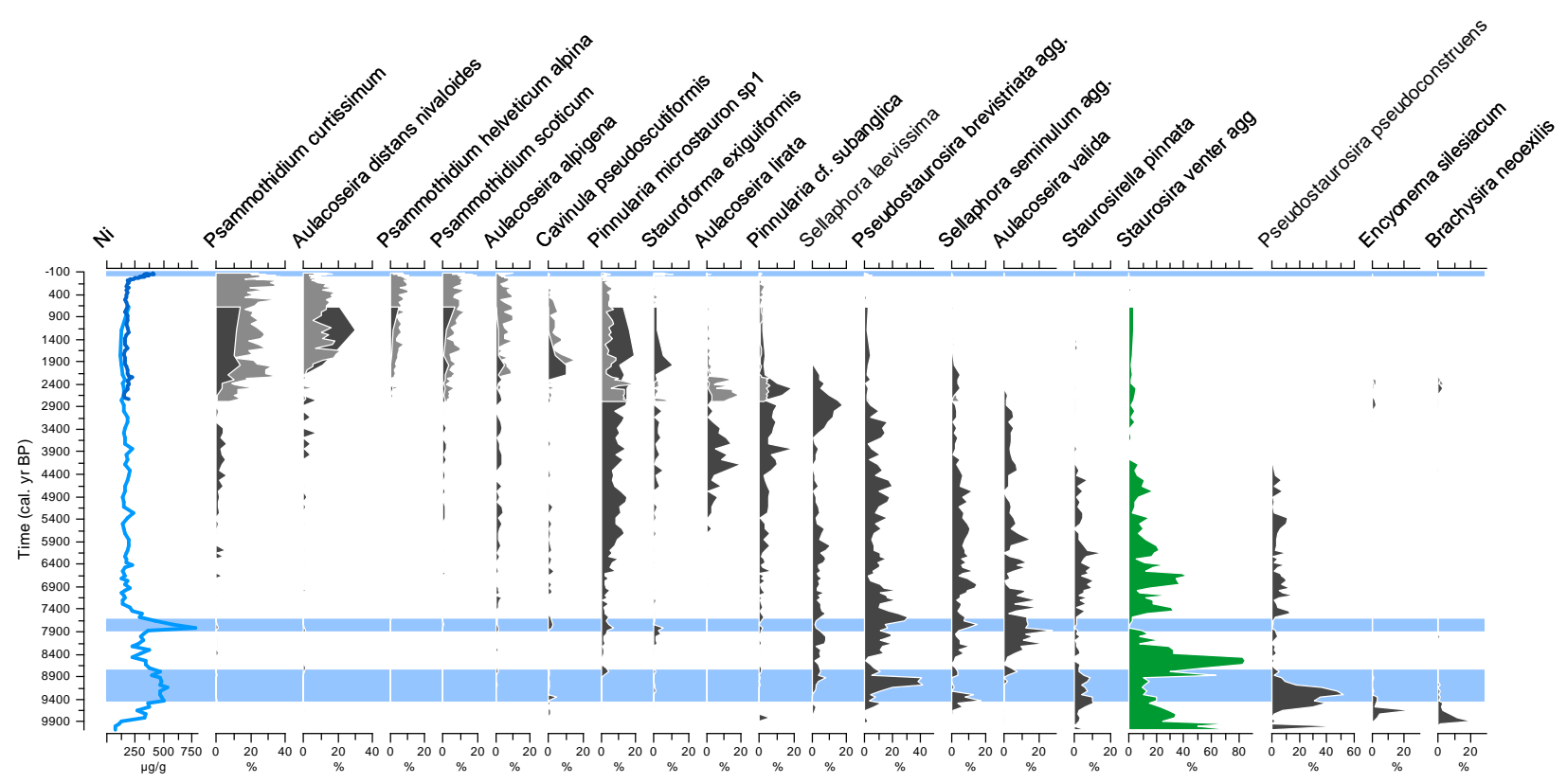

Figure 12 Nickel trends and diatom changes (\% relative abundance) in lake Rasass (cores RAS10-K1, RAS11-P1) over the last 10000 years. 
High nickel concentrations are neither driving the diatom species composition (Figure 12, and DCA axes scores in Figure 13), nor diminishing diatom species richness (Figure 13 and Figure 14). Only the abundance of Staurosira venter is depleted during the high nickel peaks in the early Holocene. As Staurosira venter is strongly dominating the diatom species composition during the early Holocene ( $\max .85 \%$ ), its depletion during high nickel peaks actually leads to an increase in diversity. In a Chord distance based RDA trying to explain the changes in diatom species composition with all geochemical parameters measured in the sediment, the first parameter selected is lead which is explaining $37.6 \%$, then additionally sulfur (7.5\%), titanium (5\%); then as seventh parameter arsenic (2.8), before nickel, copper and zinc which each explain very low amounts of variation (less than $2 \%$ ). The distinct changes in species composition seem to be driven by parameters not covered in the analyses. These are most likely climate related parameters (e.g. ice cover duration, mixing patterns, water temperature) and $\mathrm{pH}$ shifts.

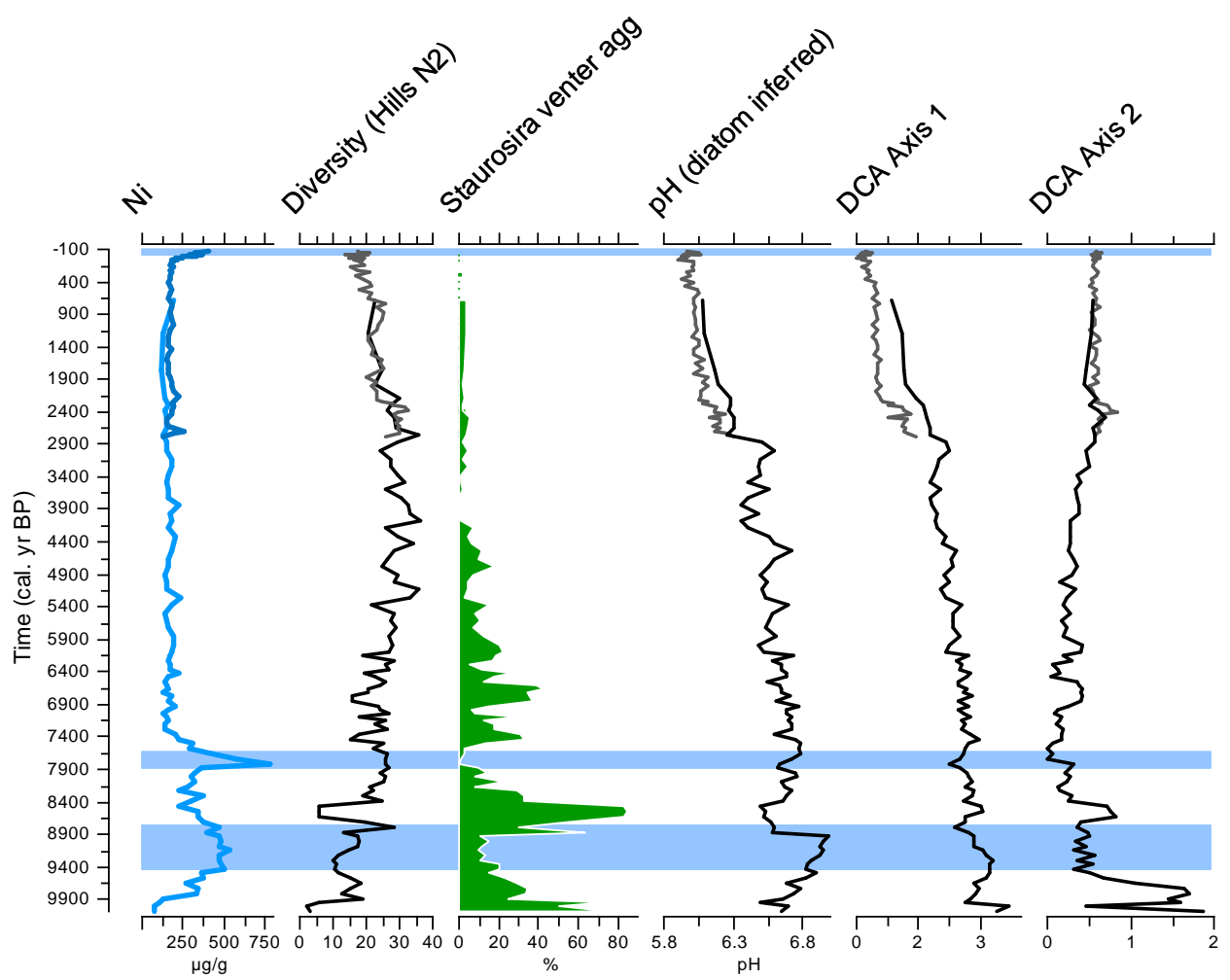

Figure 13 Stratigraphies of nickel concentration, changes in diversity (Hills N2), abundance of diatom species Staurosira venter, diatom inferred $\mathrm{pH}$, and DCA axes scores of the diatom species compositon in the cores RAS10-K1 (top) and RAS11-P1. Horizons with high nickel concentrations are highlighted in blue. Note the decrease in Staurosira venter during the nickel peaks. 


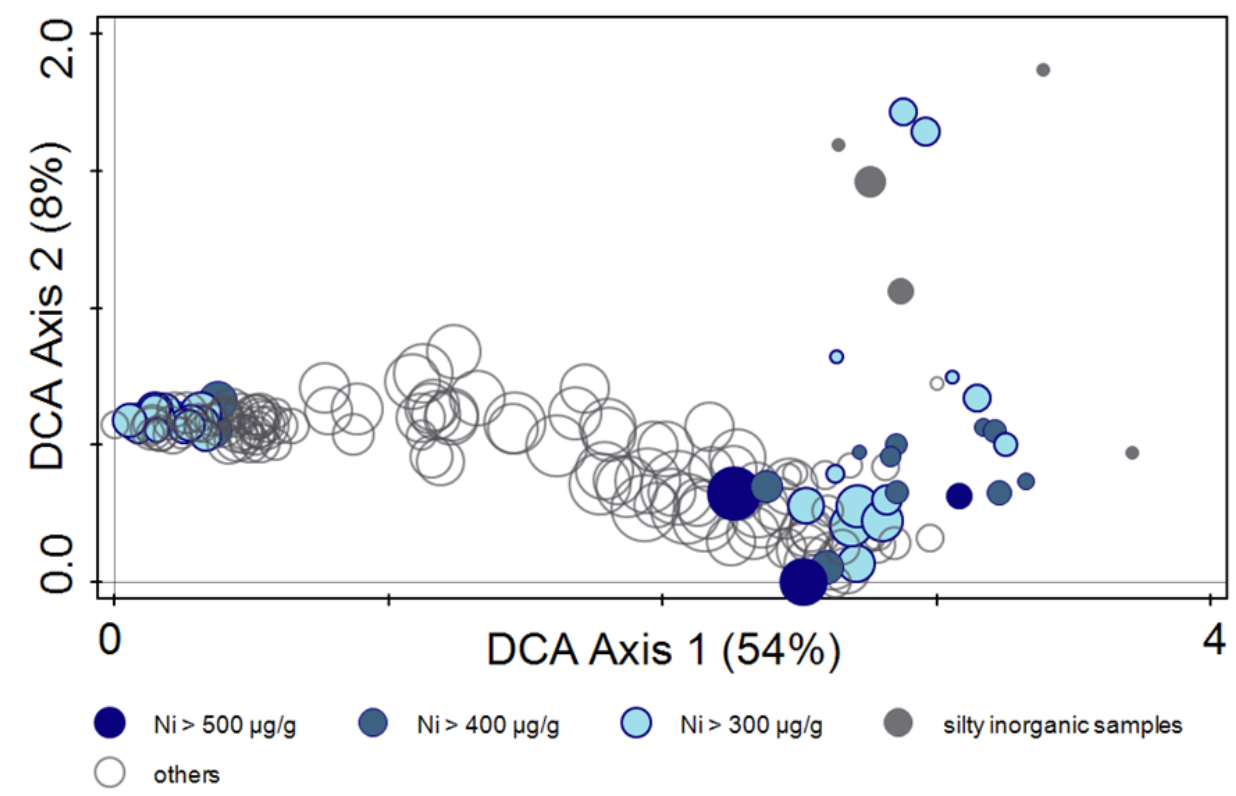

Figure 14 Species diversity in the cores RAS10-K1 and RAS11-P1: Label size reflects species richness (Hills N2 diversity index) with bigger labels reflecting greater species richness in the samples. Labels are coloured according to the nickel amount observed in the samples. High nickel amounts are not linked to less divers diatom assemblages.

Pseudostaurosira pseudoconstruens seems to be nickel tolerant and is accounting for up to $52 \%$ of the diatoms species composition during the lower nickel peak, i.e. between 9330 and 8900 cal. yr BP (Figure 12). At the same time this taxon is showing a high amount of valve deformations (Figure 15) in these layers; up to $68 \%$ of the Pseudostaurosira psendoconstruens valves are distorted. However, during the most recent layers with high nickel concentrations, Pseudostaurosira pseudoconstruens is absent. In general, the occurrence of Pseudostaurosira pseudoconstruens is independent of the nickel concentration (Figure 6). In contrast, the amount of deformation observed in Psendostaurosira psendoconstruens in the samples is significantly influenced by the nickel concentration measured in the same sediment layers $\left(\mathrm{R}^{2}=0.69 ; \mathrm{p}<0.001 ;\right.$ Figure 7)
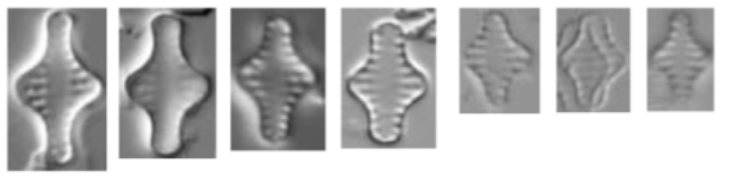

$10 p m$
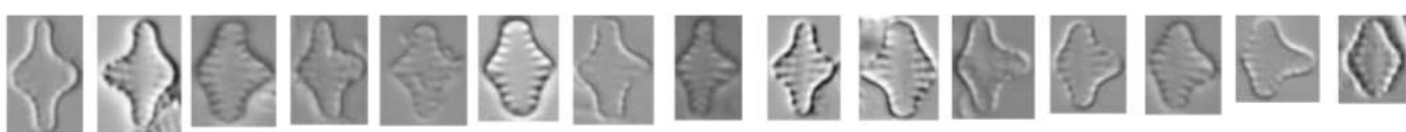

Figure 15 Pictures of normal (top row) and distorted (bottom row) Pseudostaurosira pseudoconstruens valves in Rasass See. 


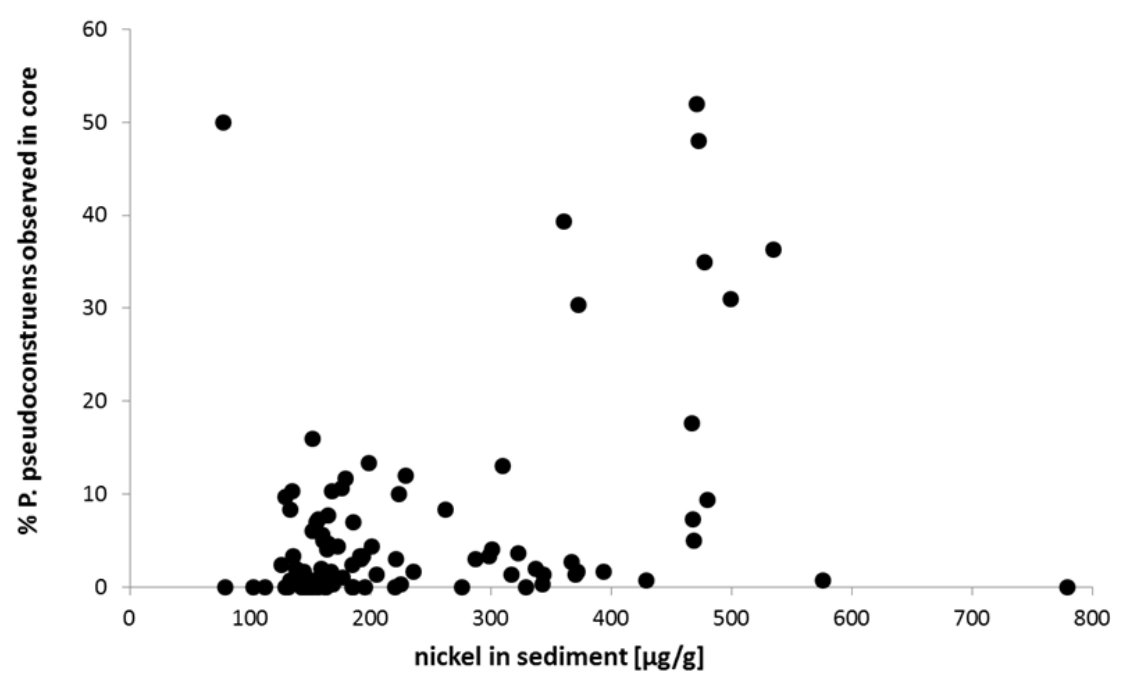

Figure 16 Occurrence of Pseudostaurosira pseudoconstruens compared to nickel concentrations observed in each sediment layer. The abundance of Pseudostaurosira pseudoconstruens is changing independently of nickel concentrations.

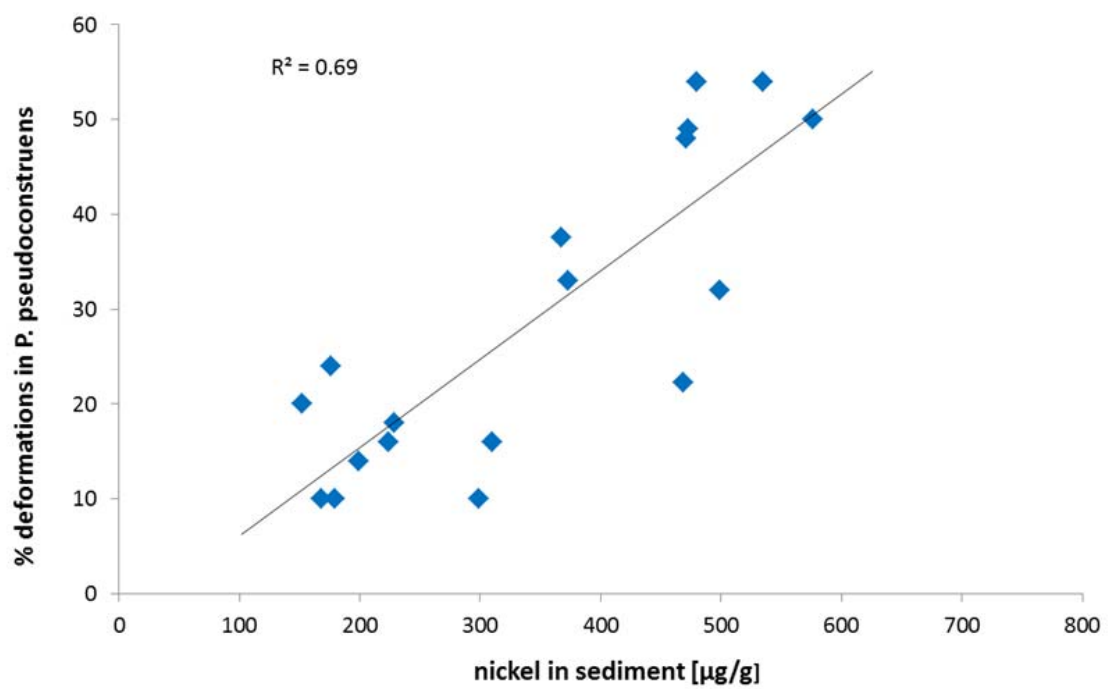

Figure 17 Occurrence of deformations in Pseudostaurosira pseudoconstruens compared to nickel concentrations observed in each sediment layer. With increasing amount of nickel, deformation of Pseudostaurosira pseudoconstruens is significantly increasing $\left(R^{2} 0.69, p<0.001\right)$. 


\subsection{Effects on chironomids and other invertebrates}

The chironomid stratigraphy (Figure 18) is characterized by the dominance of two cold-adapted chironomid taxa, i.e. the Micropsectra radialis-type and Pseudodiamesa nivosa-type in the early Holocene (ca. 10 150-9800 cal. yr BP). After ca. 9500 cal. yr BP sharp changes occur in the chironomid assemblages. The Tanytarsus lugens-type domincance is increasing as well as the other warmer-adapted taxa Procladius, Psectrocladius sordidellus-type, Corynoneura arctica-type, Zavrelimiya type A, Heterotrissocladius grimshawi-type and Heterotrissocladius marcidus-type, and an increase in daphnia ephippium and chironomid head capsule concentrations is observed. Altogether, the faunistic features of the record suggest a warmer and more productive environment during the period ca. 9500-2000 cal. yr BP. A temporary cooling at ca. 8200-8000 cal yr BP is evident from an increase in Micropsectra radialis-type during this period. This is also reflected in the chironomid PCA Axis 1 sample scores. The coldest water occurs in the lake during the last 2000 years as evidenced by a high abundance of Psendodiamesa nivosa-type and Micropsectra radialis-type. The concentration of chironomid head capsules (Figure 20) is the lowest during the last two millennia. This suggests a decline in lake productivity associated with generally colder environments. In the last decades, however, the abundance of Pseudodiamesa nivosa-type is rapidly decreasing while Micropsectra radialis-type becomes more abundant, which suggests a warming trend.

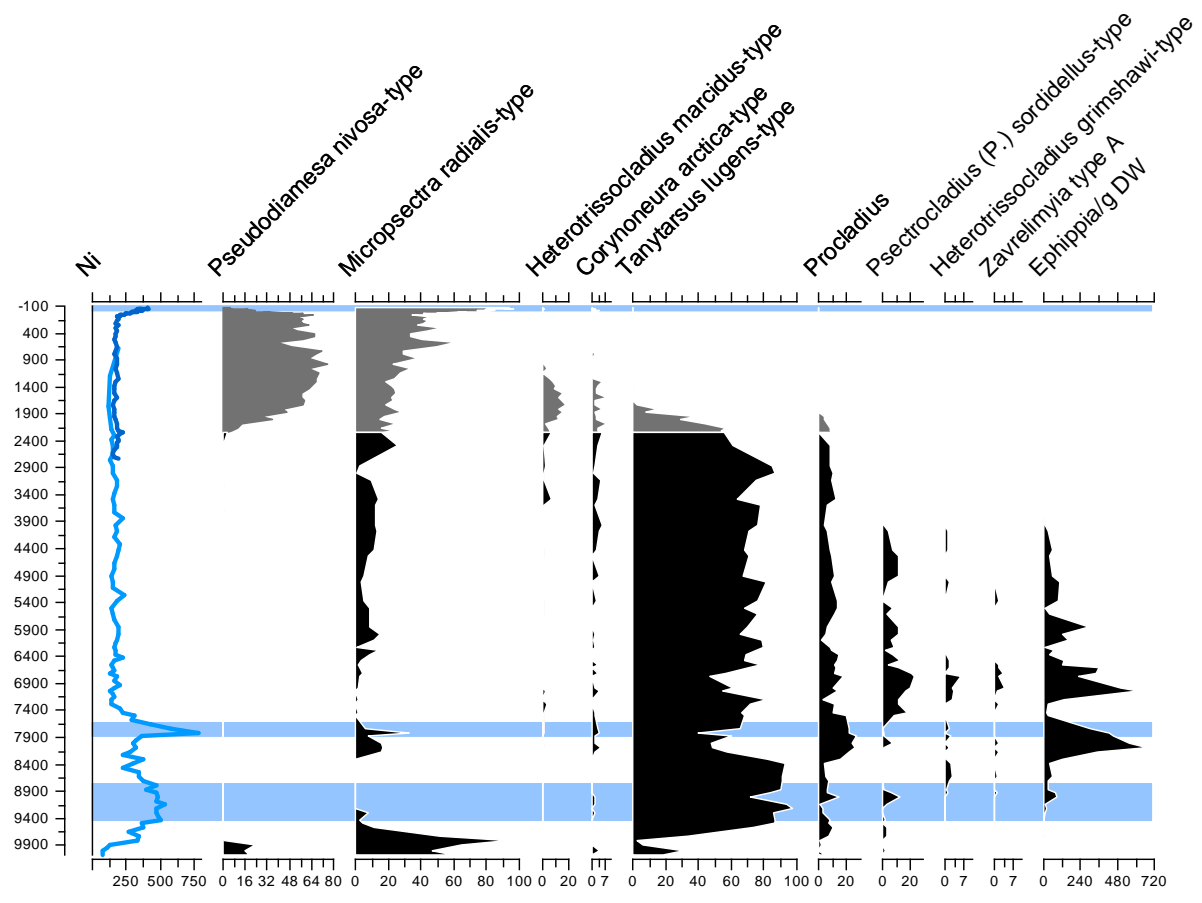

Figure 18 Nickle concentrations and relative abundance of selected chironomid taxa in the short sediment core RAS10K2 and the long sediment core RAS11-P1. 
The species changes observed in the chironomid assemblage itself is not driven by the high metal and nickel loads observed in the sediment (Figure 18). None of the species observed in Rassas See shows consistent depletions during periods with high nickel concentrations. For example, Micropsectra radialis-type is very abundant in the uppermost core layers despite nickel concentrations above 400 $\mu \mathrm{g} / \mathrm{g}$ DW. Thus the absence during the early Holocene nickel peak (9500-8700 BP) is not caused by the equally high nickel load observed during this period.

Still, Pseudodiamesa nivosa-type is affected by the overall high metal burden observed in the lake. Analysis of the mentum of Psendodiamesa nivosa-type shows that a high incidence of mentum abnormalities (Figure 19) in the P. nivosa population was observed in the oldest core section and persisted throughout the last 2.5 millennia (Figure 20). However, Psendodiamesa nivosa-type is absent during large periods (ca. 9800-2400), and especially during the periods with the highest nickel loads observed (Figure 20). As indicated above, Pseudodiamesa nivosa-type is a cold stenothermic species and its occurrence is typically related to colder periods. In addition, metal accumulation was observed in recent chironomids sampled in various depths in the lake (Figure 21). A detailed discussion about the effect of metals on chironomids, beetles and oligochaetes in Rasass See can be found in Ilyashuk et al. (2014). The article is provided in the attachment of this report.
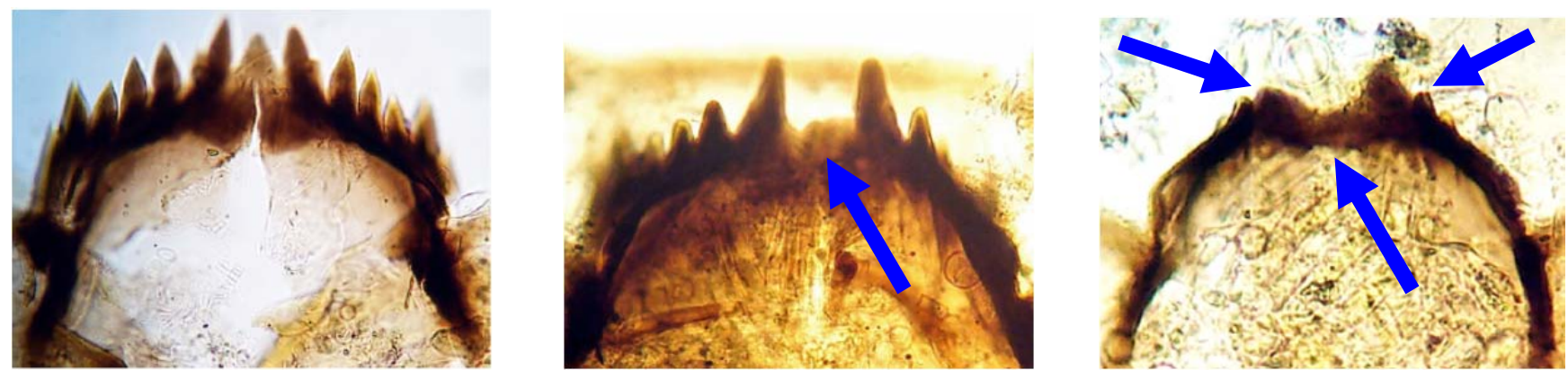

Figure 19 Mouth parts of Pseudodiames nivosa. Left: normal mentum; middle mildly and right strongly deformed mentum lacking teeth. 


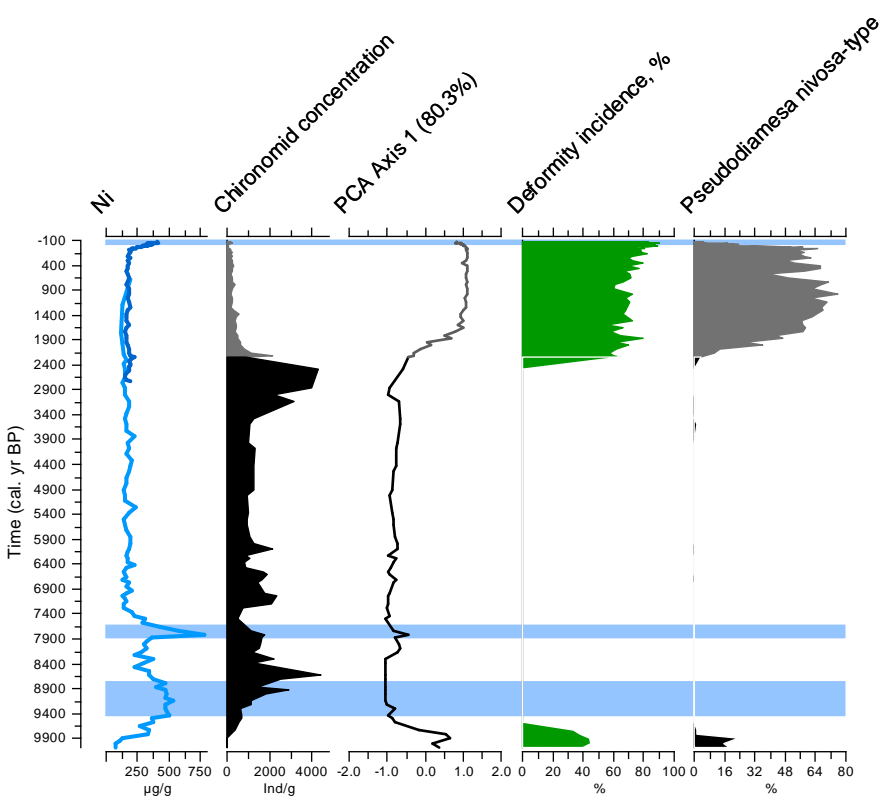

Figure 20 Nickel content in the sediment of RassasSee, and chironomid head-capsule concentration, PCA axis scores, and deformations and abundance of Pseudodiamesa nivosa.

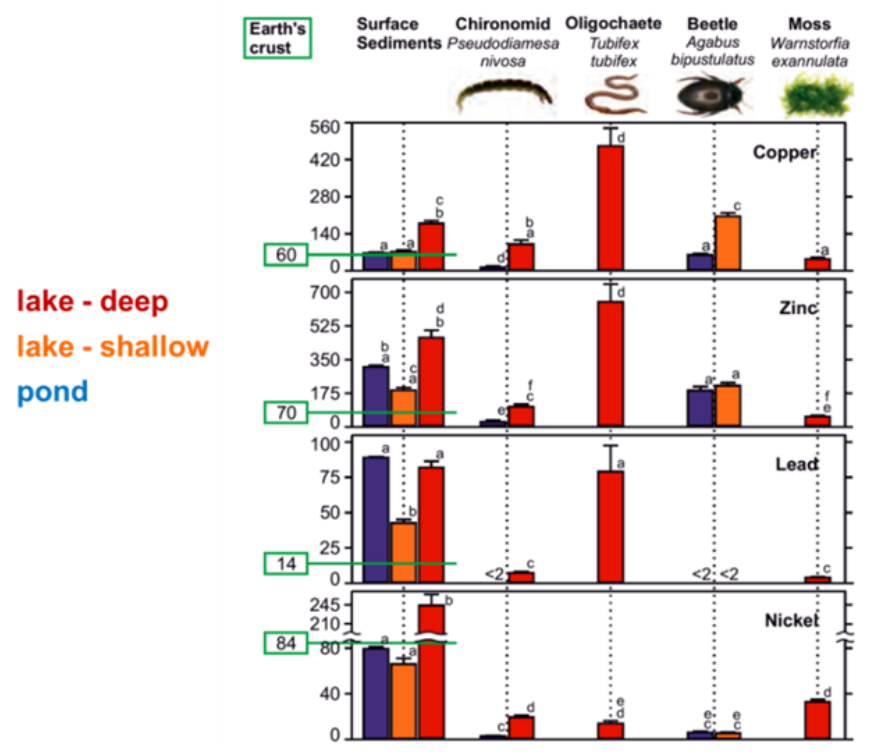

Figure 21 Concentrations (mean $\pm \mathrm{SE} ; \mathrm{n}=3$ ) of copper (a), zinc (b), lead (c), nickel (d), chromium (e), aluminium (f), iron $(\mathrm{g})$, titanium (h), manganese (i), and vanadium (j) in surface sediments and biota of RPD and the RAS shallow and deep waters. For each metal, means followed by the same letter are not significantly different (one-way ANOVA, Bonferroni post hoc test, $p<0.05$ ). The abundances of the chemical elements in the Earth's continental crust are shown with green lines. See llyashuk et al. 2014 for details. 


\subsection{Metal accumulation in fish}

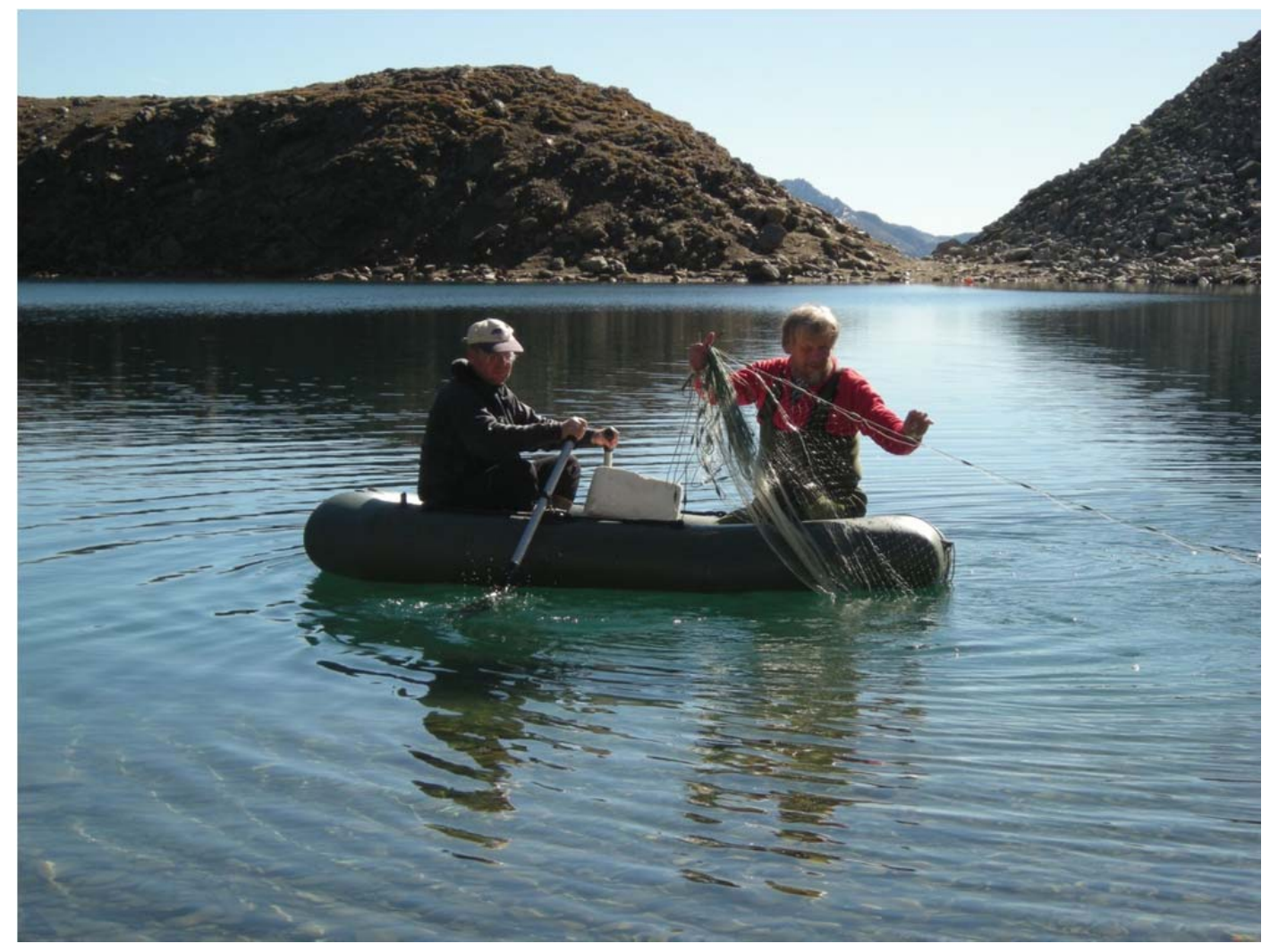

Figure 22 Fishing at Schwarzsee ob Sölden Sept. 2010. (Foto G. Krauthackl)

\section{Biometric data:}

Total Length and weight of fish ranged between 16.5- $26.0 \mathrm{~cm}$ and 12.8 and $81.3 \mathrm{~g}$, respectively (Figure 23). Sizes of fish caught were similar to those sampled in this lake in the 1990s (Köck et al. 1995).

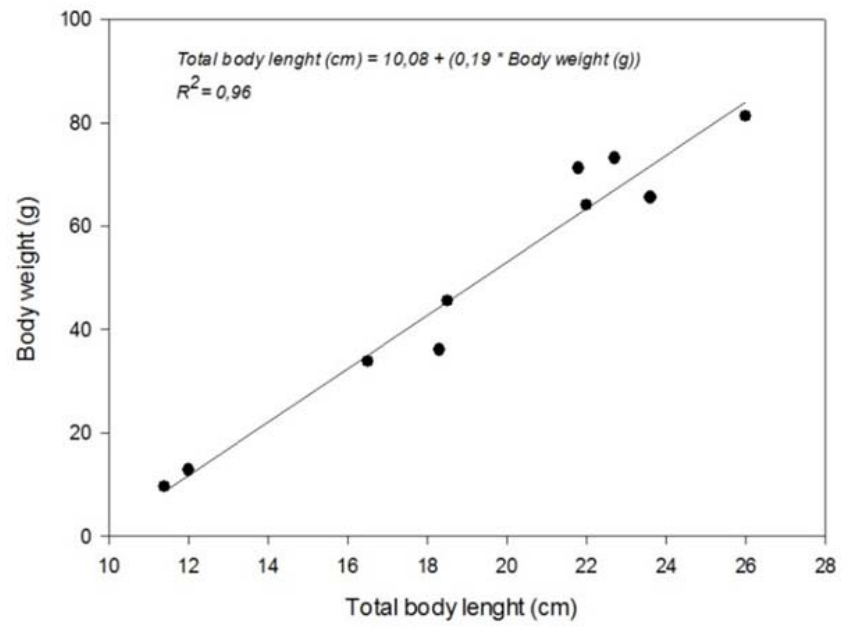

Figure 23 Correlation between total length and body weight of Arctic char caught in 2010 in SOS 


\section{$\mathrm{Cd}, \mathrm{Pb}, \mathrm{Cu}, \mathrm{Zn}$}

A comparison between metal concentration in liver and kidney samples from 1992, 2007 and 2010 show remarkable differences between metal species (Tab. 2). While tissue concentrations of $\mathrm{Cu}$ and $\mathrm{Zn}$ (both elements are essential for many metabolic processes such as protein synthesis) remained relatively stable between 1992 and 2010, whereas concentrations of $\mathrm{Cd}$ and $\mathrm{Pb}$ decreased considerably within this period of time. For instance, $\mathrm{Cd}$ and $\mathrm{Pb}$ concentrations in the kidney dropped by a factor of 2.6 from approx. $95 \mathrm{mg} / \mathrm{kg} \mathrm{Cd}$ to $36 \mathrm{mg} / \mathrm{kg} \mathrm{Cd}$ and by a factor of 5.4 from approx. $25 \mathrm{mg} / \mathrm{kg} \mathrm{Pb}$ to $4.6 \mathrm{mg} / \mathrm{kg} \mathrm{Pb}$, respectively.

Table 2 Metal concentrations (Means \pm SE; dry weight; 1992: $n=15 ; 2007: n=14 ; 2010: n=8$ ) in liver and kidney of Arctic char (Salvelinus alpinus) from Schwarzsee ob Sölden (* from Köck et al. 1995; **unpublished data from the research project High-Arctic 1997-2014)

\begin{tabular}{|c|c|c|c|c|c|c|}
\hline Tissue & Year & $\mathrm{Ni}$ & Cd & $\mathrm{Pb}$ & $\mathrm{Zn}$ & $\mathrm{Cu}$ \\
\hline Liver & 1992 & & $30-40$ & $6-10$ & $125-155$ & $110-170$ \\
\hline Liver & 2007 & $0.87 \pm 0.12$ & $24.04 \pm 5.68$ & $2.89 \pm 0.94$ & $196.6 \pm 8.36$ & $142.06 \pm 18.9$ \\
\hline Liver & 2010 & $1.7 \pm 0.4$ & $17.6 \pm 4.1$ & $3.4 \pm 0.6$ & $149.0 \pm 9.5$ & $228.6 \pm 63.2$ \\
\hline Kidney & 1992 & & $80-110$ & $20-30$ & $140-175$ & $17-45$ \\
\hline Kidney & 2010 & $5.1 \pm 1.1$ & $36.3 \pm 4.9$ & $4.6 \pm 1.1$ & $128.4 \pm 4.6$ & $14.4 \pm 1.7$ \\
\hline
\end{tabular}

The decrease of $\mathrm{Cd}$ and $\mathrm{Pb}$ tissue concentrations coincides with significant changes of lake water conditions over the past two decades (Tab. 3). While concentrations of $\mathrm{Cd}$ and $\mathrm{Pb}$ in the water have dropped by a factor of 100, Ca and total cations increased by a factor of 2.5 and $\mathrm{pH}$ increased almost by one unit to $\mathrm{pH}$ 6.29. Furthermore, lake water concentration of $\mathrm{Cd}$ and $\mathrm{Pb}$ are by a factor of 100 lower than in 1992. The changes in water conditions could be attributed to climate change driven weathering processes and a shortening in the ice cover duration by several weeks. As a consequence, the decrease of $\mathrm{Cd}$ and $\mathrm{Pb}$ concentrations in char tissues has to be attributed to a decreasing bioavailability of $\mathrm{Cd}$ and $\mathrm{Pb}$ for fish under more alkaline water conditions.

Table 3 Chemical characteristics (mean values) of Schwarzsee ob Sölden (* from Köck et al. 1995; **unpublished data from High-Arctic 1997-2014). Water samples for metal analyses were filtered through $0.45 \mu \mathrm{m}$ pore -size filter.

\begin{tabular}{|c|c|c|c|c|c|c|c|}
\hline Year & $\begin{array}{l}\text { Conductivity } \\
\left(\mu \mathrm{S}^{*} \mathrm{~cm}^{-1}\right)\end{array}$ & $\mathrm{pH}$ & $\begin{array}{c}\text { Alk } \\
\left(\mu e{ }^{*} L^{-1}\right)\end{array}$ & $\begin{array}{c}\mathrm{Cd}^{++} \\
\left(\mu e q^{*} L^{-1}\right)\end{array}$ & $\begin{array}{c}\mathrm{Pb}^{++} \\
\left(\mu e q^{*} \mathrm{~L}^{-1}\right)\end{array}$ & $\begin{array}{l}\text { Ni lake water } \\
\qquad\left(\mu e{ }^{*} L^{-1}\right)\end{array}$ & $\begin{array}{l}\text { Ni inflow } \\
\left(\mu e{ }^{*} L^{-1}\right)\end{array}$ \\
\hline 1992* & 11.6 & 5.58 & 11 & 0.114 & 0.504 & & \\
\hline $2007 * *$ & 32.9 & 6.18 & 16 & & & & \\
\hline 2010 & 32.1 & 6.29 & 11 & $<0.001$ & $<0.005$ & 0.007 & 0.024 \\
\hline
\end{tabular}


Ni:

Concentrations of $\mathrm{Ni}$ in liver and kidney tissues of char from SOS were low and in the case of the liver close to detection limits (Tab. 2). Concentrations are lower than normal values for liver and kidney, i.e. $1.5 \mathrm{mg} / \mathrm{kg}$ (fresh weight) for rainbow trout suggested by WHO (WHO 1991, Eisler 1998).

Data on Ni toxicity to European fish species are still limited. The chemical and physical forms of Ni strongly influence bioavailability and toxicity in aquatic ecosystems (Köck 1996, Eisler 1998). Nickel can occur in the aquatic environments as soluble Ni salts, adsorbed on suspended solids, and as organic complexes. In natural waters the divalent cation $\mathrm{Ni}^{++}$is the predominating chemical species, being almost the sole form present in the $\mathrm{pH}$ range 7-9 in most aerobic waters (Calamari et al. 1994, Svecevičius 2010). $\mathrm{Ni}^{++}$is hardly accumulated by, and of relatively low toxicity to, fish. Overall, Ni has little capacity for accumulating in fish tissue. Eisler (1998) reported ionic Ni to be lethal (LC10) to rainbow trout embryos at $11 \mu \mathrm{g} \mathrm{Ni} / \mathrm{L}$ (Birge and Black 1980) and sublethal effects (altered immunoregulatory mechanisms) in rainbow trout at $11.7 \mu \mathrm{g} \mathrm{Ni} / 1$ (Bowser et al. 1994). Köck (1996) reported the lowest effect concentration of $\mathrm{Ni}$ to salmonid fish (avoidance reaction) to be $0.024 \mathrm{mg} \mathrm{Ni} / \mathrm{L}$ for water conditions of $\mathrm{pH}$ 7.3. Tests on rainbow trout eggs revealed decreased growth rates of freshly hatched larvae at a Ni concentration of $0.035 \mathrm{mg} \mathrm{Ni} / 1$ at $\mathrm{pH} 7$ (Nebeker et al. 1985). For waters of soft and medium water hardness, Köck (1996) suggested maximum concentrations of $10-20 \mu \mathrm{g} \mathrm{Ni} / \mathrm{L}$ and $30-50 \mu \mathrm{g} \mathrm{Ni} / \mathrm{L}$, respectively.

\section{Hg:}

Temporal trend of $\mathrm{Hg}$ concentration in muscle tissue of Arctic char from SOS show a significant increase of $\mathrm{Hg}$ concentrations between 1994 and 2007 (Fig. 2). Hg concentrations in fish samples from 2011 were significantly lower than in 2007 but with $0.05 \mu \mathrm{g} / \mathrm{g} \mathrm{Hg}$ still significantly higher than in 1994. Data from the research project High-Arctic show that $\mathrm{Hg}$ concentrations in fish from SOS are similar to those from char from another Austrian high mountain lake, Rotfelssee, where $\mathrm{Hg}$ concentrations in muscle samples in 2004, 2005 and 2007 revealed relatively stable $\mathrm{Hg}$ values between 0.053 - $0.063 \mu \mathrm{g} / \mathrm{g}$ (High-Arctic 1997-2014, unpublished data).

A comparison with studies carried out on fish from lakes in the Canadian Arctic show that $\mathrm{Hg}$ concentration in Arctic char from SOS and Rotfelssee are much lower than in char from Canadian Arctic lakes: for instance, $\mathrm{Hg}$ concentrations in Arctic char from Resolute Lake (Cornwallis Island, Nunavut Canada) sampled in the period from 1997-2013 ranged between 0.12 and $0.3 \mu \mathrm{g} / \mathrm{g}$ (Muir et 
al. 2014). Since studies on $\mathrm{Hg}$ accumulation in char from Canadian Arctic lakes show a relation to the warming trend in Polar regions, it is recommended to monitor $\mathrm{Hg}$ concentrations in fish from Austrian high mountain lakes on a regular basis to learn more about the effects of climate warming on Alpine freshwater ecosystems.

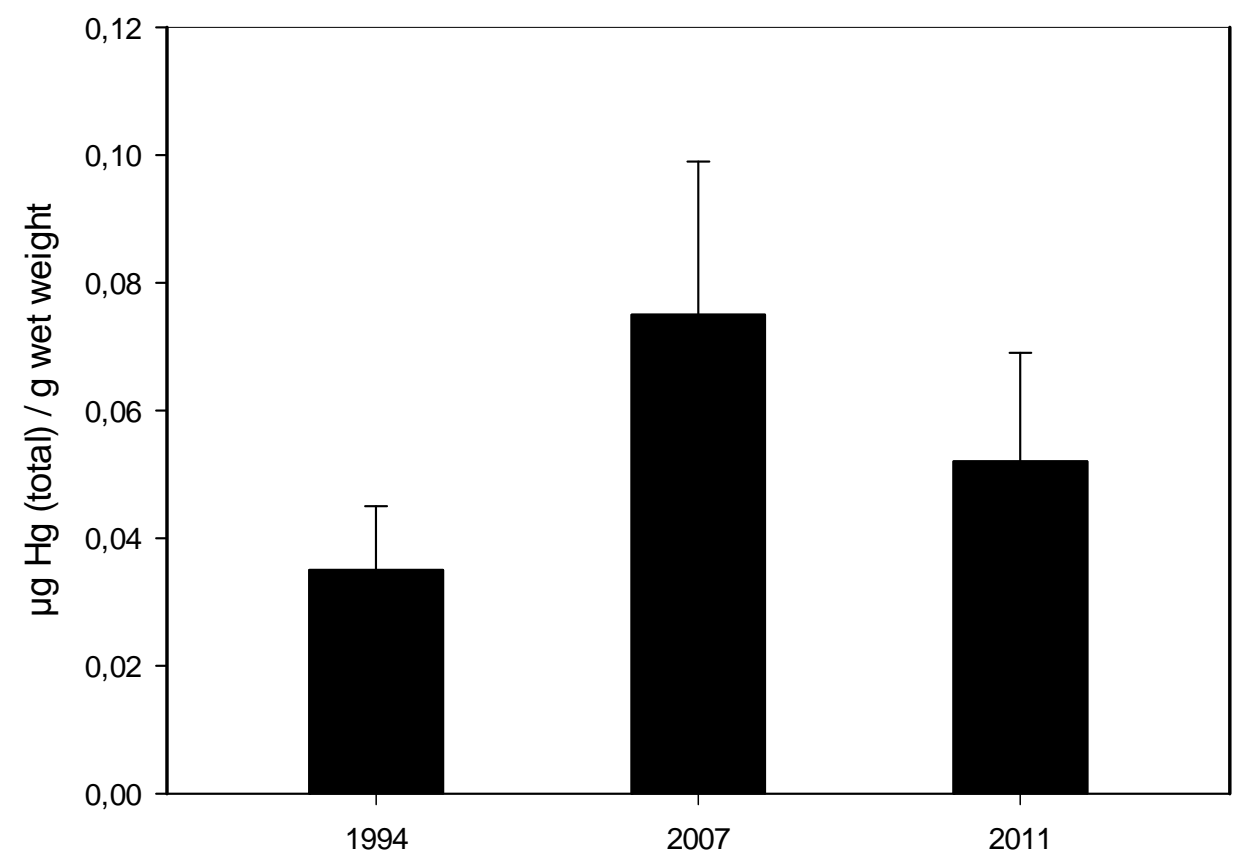

Figure $24 \mathrm{Hg}$ concentrations (Means \pm SE; dry weight; 1994: $n=7 ; 2007: n=21 ; 2011: n=8$ ) in muscle tissue of Arctic char (Salvelinus alpinus) from SOS (1994: Wathne 1995; 2007: unpublished data from the research project High-Arctic 1997-2014) 


\section{Presentations and OUtreach}

\subsection{Publications}

Ilyashuk B.P., Ilyashuk E.A., Psenner R., Tessadri R. and Koinig K.A. 2014. Rock glacier outflows may adversely affect lakes: lessons from the past and present of two neighboring water bodies in a crystalline-rock watershed. Environmental Science \& Technology 48: 6192-6200.

Schlüter M., Hentzel T., Suarez C., Koch M., Lorenz W.G., Böhm L., Düring R., Koinig K.A. and Bunge M. 2014. Synthesis of novel palladium(0) nanocatalysts by microorganisms from heavy-metal-influenced high-alpine sites for dehalogenation of polychlorinated dioxins. Chemosphere 117, 0: 462-470.

Koinig K.A., Ilyashuk B.P., Ilyashuk E.A., Pla S., Köck G., Tessadri R., Psenner R. (in prep. Including parts of this report): Recent and long term trends in rock glacier weathering and its effect on metal loads in a high mountain lake.

\subsection{Master Thesis carried out in cooperation with this project}

Kai Guckes (2012): Persistente Umweltschadstoffe im Sediment alpiner Hochgebirgsseen als Folge der globalen Destillation: dargestellt am Beispiel des Rasass Sees, Südtirol. Mater Thesis. IFZ University of Giessen (Supervisor: M. Bunge)

(Google eBook: http://books.google.at/books?id=817POZy62pcC\&hl=de\&source=gbs_navlinks_s )

\subsection{BAK Theses supervised within this project}

Wegscheider Bernhard (2012): Diatomeenkonzentration in Sedimenten vom Rasass See Bachelor Thesis, Institute of Ecology, University of Innsbruck (Supervisor K.A. Koinig)

Christian Fohringer (2014): Processing and compiling the basic parameters of a sediment core covering the last 10,000 years: Dry weight, density, organic parameters, and interpretation of long-term changes Bachelor Thesis, Institute of Ecology, University of Innsbruck (Supervisor K.A. Koinig)

\subsection{Oral presentations}

Koinig Karin A., E. Ilyashuk, B. Ilyashuk, S. Pla, R. Psenner (2013): Climate driven natural variation in metal loads and their impact on aquatic organisms in alpine lakes 32nd SIL Meeting (International Society of Limnology), Budapest, 4-9th August 2023

Koinig Karin A.(2012): Long term climate change in the Alps over the last 10,000 years 6th AFI Symposium, Christmas Colloquium, "Gravitational Puzzles", Innsbruck, 07.12.2012

Koinig, K.A., Ilyashuk, E.; Psenner R. (2012): The nickel conundrum of Alpine Lakes. ASLO Aquatic Sciences Meeting: Voyages of Discovery, Lake Biwa, Otsu, Shiga, 10.07.2012.

Koinig, Karin A.; Ilyashuk, E.; Ilyashuk, B.; Tessadri, R.; Psenner, R. (2011) Holocene development of a bigh alpine lake controlled by climate, catchment processes, and seasonality shifts in insolation. ILIC International Limnogeology Congress, Konstanz, 30. Aug- 3. Sept 
Koinig, Karin A.; Ilyashuk, E.; Ilyashuk, B.; Tessadri, R.; Psenner, R. (2011): Metling permafrost-influence on water quality. Leopold-Franzens-Universität Innsbruck - Institut für Geologie und Paläontologie, Innsbruck, 13.01.2011

Koinig Karin A., E. Ilyashuk, R. Lackner, G. Köck, R. Psenner (2011): Der Einfuss schmelzenden Permafrostes auf die Wasserqualität und die aquatischen Organismen alpiner Seen - Untersuchungen an Seesedimenten. Interdisciplinary Lecture Innsbruck: Klimageschichte entlang langer und kurzer Zeitreihen,

Koinig Karin A., E. Ilyashuk, R. Lackner, G. Köck, R. Psenner (2010): Der Einfuss schmelzenden Permafrostes auf die Wasserqualität und die aquatischen Organismen alpiner Seen - Untersuchungen an Seesedimenten. Permafrost Workshop Obergurgl, 14-15 Oktober 2010

\subsection{Posterpresentations}

Köck, G.; Muir, D.; Lackner R.; Tessadri, R.; K. Koinig (2015): Temporal trends of heavy metal concentrations in Arctic Char (Salvelinus alpinus) from an Austrian High Mountain Lake: effects of climate- induced changes in lake water chemistry SETAC Europe $25^{\text {th }}$ annual meeting in Barcelona, 3-7 May 2015

Köck, G.; Lackner R.; Muir, D.; Tessadri, R.; K. Koinig (2015): Effects of climate- induced changes in lake water chemistry on heavy metal concentrations in Arctic Char (Salvelinus alpinus) from an Austrian High Mountain Lake, Perth III: Mountains of Our Future Earth, Perth Scotland, 4-8 October 2015

Ilyashuk, B. P.; Koinig, K. A.; Ilyashuk, E. A.; Tessadri, R.; Psenner, R. (2013): Adverse effects of natural acid rock drainage on aquatic macroinvertebrates in the upper Vinschgau Valley, Central Eastern Alps, Italy. In: SIEEC 23: The 23rd Symposium Internationale Entomofaunisticum Europae Centralis. September 09-13, 2013, Bolzano/Bozen, Italy. Program and Abstract Book. Bozen: Naturmuseum Südtirol, S. 37 - 38.

Ilyashuk, B. P.; Koinig, K. A.; Ilyashuk, E. A.; Tessadri, R.; Psenner, R. (2013): Permafrost melting and ecotoxicological consequences in a periglacial lake in the Eastern Alps: Answers from the past and present. In: The Past: A Compass for Future Earth. The 4th PAGES Open Science Meeting, 13-16 February 2013, Goa, India. Program and Abstract Book. Bern: PAGES International Project Office, S. 196.

Ilyashuk, E. A.; Tylmann, W.; Ilyashuk, B. P.; Koinig, K. A.; Psenner, R. (2013): Longterm changes in non-biting midge (Diptera: Chironomidae) diversity in the Tyrolean Alps. In: SIEEC 23: The 23rd Symposium Internationale Entomofaunisticum Europae Centralis. September 09-13, 2013, Bolzano/Bozen, Italy. Program and Abstract Book. Bozen: Naturmuseum Südtirol, S. 38 - 39.

Koinig, Karin A.; Ilyashuk, E.; Ilyashuk, B.; Tessadri, R.; Psenner, R. (2012): The impact of climate on metal loads and aquatic organisms in alpine lakes. In: 'advancing the science of palaeolimnology'. 12th International Paleolimnology Symposium (IPS2012). Book of Abstracts. International Paleolimnology Association (IPA), S. 106.

Ilyashuk, E.A.; Koinig, K.A.; Psenner, R. (2010): The warm early Holocene - a clue for future global change effects in high elevation lakes? In: Proceedings of the 31st Congress of SIL in Cape Town. 15.-20.8.2010, CD of Abstracts. Cape Town: SIL.

\subsection{Documentation for Television}

ORF Universum: "Fünf Grad Plus", In September 2010 we were filmed at Schwarzsee explaining climate impacts and Holocene trends for "Universum", the television natural science programme of the ORF, the Austrian national public service broadcaster. In Spring 2011, G. Köck and K. Koinig were also filmed in the lab preparing samples. Broadcasting will take place in autumn 2011.

Koinig, Karin A. (2011): EC Educational program ComScience. Digital Learning Resources - Film contribution explaining the principal of palaeolimnology (producer: Pechan P.). 


\subsection{Print media/public outreach}

Köck, G. (2011): Tauwetter: Permafrost in den Alpen. Bergauf - Das Magazin des Österreichischen Alpenvereins, 04/2010, 18-20. Link: http://www.my-catalog.biz/R101655/

Günther Krauthack in Kooperation mit Köck Günter, Geheimnis des Klimawandels lüften. Kronenzeitung Tirol, 25/07/2011. (von Günther Krauthackl).

\section{$5.8 \quad$ Internet}

Access to the principle information about the aims of the project can be assessed online:

http://www.uibk.ac.at/ecology/staff/koinig/projects_koinig.html

Abstract in English:

http://www.uibk.ac.at/ecology/forschung/metling_permafrost_lake_organism_water-quality_eng.pdf Abstract in German:

http://www.uibk.ac.at/ecology/forschung/metling_permafrost_seen_lebewelt_wasserqualitaet_de.pdf 


\section{REFERENCE LIST}

Alabaster, J.S., Lloyd, R., 1980. Water quality criteria for freshwater fish. Butterworths, London, UK, p. 384.

Andersen T., Ekrem T., Cranston P.S. (Eds). 2013. Chironomidae of the Holarctic Region. Keys and diagnoses - Larvae. Insect Systematics and Evolution Supplement 66, 1-571.

Battarbee, R.W., Jones, V.J., Flower, R.J., Cameron, N.G., Bennion, H., Carvalho, L., Juggins, S., 2001. Diatoms. Kluwer Academic Publishers, Dordrecht, The Netherlands.

Birge, W.J., Black, J.A. (1980). Aquatic toxicology on nickel. In: Nickel in the environment. J.O. Nriagu (ed.), J. Wiley \& Sons, New York. 349-366.

Bowser, D. H., Frenkel, K., Zelikoff, J.T. (1994). Effects of in vitro nickel exposure on the macrophagemediated immune functions of rainbow trout (Oncorhynchus mykiss). Bull. Environ. Contam. Toxicol. $52,367-373$

Brooks, S.J., Langdon, P.G., Heiri, O., 2007. The Identification and Use of Palaearctic Chironomidae Larvae in Palaeoecology. Quaternary Research Association, London.

Calamari, D., Lloyd, R., Solbe, J.F. (1994). Nickel and Freshwater Fish. In: Water Quality for Freshwater Fish. G. Howells (ed.), Gordon and Breach Science Publishers.

Carlisle, D.M., 2000. Bioenergetic food webs as a means of linking toxicological effects across scales of ecological organisation. Journal of Aquatic Ecosystems Stress Recovery 7, 155-165.

Cattaneo, A., Couillard, Y., Wunsam, S., Courcelles, M., 2004. Diatom Taxonomic and Morphological Changes as Indicators of Metal Pollution and Recovery in Lac Dufault (Quebec, Canada). Journal of Paleolimnology 32, 163-175.

Clements, W.H., 1999. Metal Tolerance and Predator-Prey Interactions in Benthic Macroinvertebrate Stream Communities. Ecological Applications 9, 1073-1084.

Clements, W.H., Carlisle, D.M., Lazorchak, J.M., Johnson, P.C., 2000. Heavy Metals Structure Benthic Communities in Colorado Mountain Streams. Ecological Applications 10, 626-638.

Clements, W.H., Kiffney, P.M., 1994. Assessing Contaminant Effects at Higher Levels of Biological Organization. Environmental Toxicology and Chemistry 13, 357-359.

Cunningham, L., Raymond, B., Snape, I., Riddle, M.J., 2005a. Benthic Diatom Communities as Indicators of Anthropogenic Metal Contamination at Casey Station, Antarctica. Journal of Paleolimnology 33, 499513.

Cunningham, L., Snape, I., Stark, J.S., Riddle, M.J., 2005b. Benthic Diatom Community Response to Environmental Variables and Metal Concentrations in a Contaminated Bay Adjacent to Casey Station, Antarctica. Marine Pollution Bulletin 50, 264-275.

Dixit, A.S., Dixit, S.S., Smol, J.P., 1992. Long-Term Trends in Lake Water pH and Metal Concentrations Inferred From Diatoms and Chrysophytes in 3 Lakes Near Sudbury, Ontario. Canadian Journal of Fisheries and Aquatic Sciences 49, 17-24.

Dixit, S.S., Dixit, A.S., Smol, J.P., 1991. Multivariable Environmental Inferences Based on Diatom Assemblages From Sudbury (Canada) Lakes. Freshwater Biology 26, 251-266.

Eisler, R. (1998). Nickel hazards to fish, wildlife, and invertebrates: a synoptic review. Biological Science report USGS/BRD/BSR-1998-0001. Contaminant Hazard Reviews No. 34, 95 pp.

España, J.S., Pamo, E.L., Pastor, E.S., Andrés, J.R., Rubí, J.A.M., 2006. The Removal of Dissolved Metals by Hydroxysulphate Precipitates during Oxidation and Neutralization of Acid Mine Waters, Iberian Pyrite Belt. Aquat Geochem 12, 269-298.

Heiri, O., Lotter, A.F., 2001. Effect of Low Count Sums on Quantitative Environmental Reconstructions: an Example Using Subfossil Chironomids. Journal of Paleolimnology 26, 343-350. 
Hofer, R., Lackner, R., Kargl, J., Thaler, B., Tait, D., Bonetti, L., Vistocco, R., Flaim, G., 2001. Organochlorine and Metal Accumulation in Fish (Phoxinus Phoxinus) Along a North-South Transect in the Alps. Water Air and Soil Pollution 125, 189-200.

Ilyashuk, B., Ilyashuk, E., Dauvalter, V., 2003. Chironomid Responses to Long-Term Metal Contamination: a Paleolimnological Study in Two Bays of Lake Imandra, Kola Peninsula, Northern Russia. Journal of Paleolimnology 30, 217-230.

Ilyashuk, B.P., Ilyashuk, E.A., Psenner, R., Tessadri, R., Koinig, K.A., 2014. Rock Glacier Outflows May Adversely Affect Lakes: Lessons from the Past and Present of Two Neighboring Water Bodies in a Crystalline-Rock Watershed. Environmental Science \& Technology 48, 6192-6200.

Janssens de Bisthoven, L.G., Vermeulen, A., Ollevier, F., 1998. Experimental Induction of Morphological Deformities in Chironomus Riparius Larvae by Chronic Exposure to Copper and Lead. Archives of Environmental Contamination and Toxicology 35, 249-256.

Kiffney, P.M., Clements, W.H., 1996. Effects of Metals on Stream Macroinvertebrate Assemblages From Different Altitudes. Ecological Applications 6, 472-481.

Kim, J.J., Kim, S.J., 2003. Environmental, Mineralogical, and Genetic Characterization of Ochreous and White Precipitates from Acid Mine Drainages in Taebaeg, Korea. Environmental Science \& Technology 37, 2120-2126.

Köck, G., 1996. Die toxische Wirkung von Kupfer, Cadmium, Quecksilber, Chrom, Nickel, Blei und Zink auf Fische - Beiträge zur Festlegung vom Immissionsbereichen für Metalle für österreichische Gewässer, in: Steinberg, C., Calmanao, W., Klapper, H., D., W. (Eds.), Handbuch Angewandte Limnologie, 2. Erg.Lfg. Ecomed, Landsberg/Lech, p. 167.

Köck, G., Hofer, R. (1998). Origin of cadmium and lead in clear softwater lakes of high altitude and high latitude, and their bioavailability and toxicity to fish. In: Fish Ecotoxicology (T. Braunbeck, D.E. Hinton, B. Streit), Birkhäuser Verlag Basel/ Switzerland, pp 225-257.

Köck, G., Hofer, R., Wögrath S. (1995). Accumulation of trace metals (Pb, Cd, Cu, Zn) in Arctic char (Salvelinus alpinus) from oligotrophic Alpine lakes: relation to lake alkalinity. Canadian Journal of Fisheries and Aquatic Sciences 52(11), 2367-2376.

Köck, G., Hofer, R., Wögrath, S., 1995. Accumulation of trace metals (Cd, Pb, Cu, Zn) in Arctic char (Salvelinus alpinus) from oligotrophic Alpine lakes: relation to alkalinity. Canadian Journal of Fisheries and Aquatic Sciences 52, 2367-2376.

Köck, G., Muir, D., Wang, X., Iqaluk, D., Drevnick, P., Lescord , G., Reist, J., Babaluk, J., Flannigan, M., Niederstätter, H.(2012).Temporal trends of cadmium in landlocked Arctic Char (Salvelinus alpinus) in the Canadian High Arctic: the possible influence of climate change. 6th STEAC World Congress, May 20 - 24, 2012, Berlin (Germany).

Köck, G., Noggler, M., Hofer, R. (1996b). Pb in otoliths and bones of Arctic char (Salvelinus alpinus) from oligotrophic lakes. Water Research 30(8), 1919-1923.

Köck, G., Triendl, M., Hofer, R. (1996a). Seasonal patterns of metal accumulation in Arctic char (Salvelinus alpinus) from an oligotrophic Alpine lake related to temperature. Canadian Journal of Fisheries and Aquatic Sciences 53(4), 780-786.

Köck, G., Triendl, M., Hofer, R. (1998). Lead (Pb) uptake in Arctic char (Salvelinus alpinus) from oligotrophic alpine lakes: gills versus digestive tract. Water, Air, and Soil Pollution 102, 303-312.

Köck, G., Triendl, M., Hofer, R., 1996. Seasonal Patterns of Metal Accumulation in Arctic Char (Salvelinus Alpinus) From an Oligotrophic Alpine Lake Related to Temperature. Canadian Journal of Fisheries and Aquatic Sciences 53, 780-786.

Larsson, P., 1984. Transport of Pcbs From Aquatic to Terrestrial Environments by Emerging Chironomids. Environmental Pollution Series a-Ecological and Biological 34, 283-289.

Lukin, A., Dauvalter, V., Kashulin, N., Yakovlev, V., Sharov, A., Vandysh, O., 2003. Assessment of CopperNickel Industry Impact on a Subarctic Lake Ecosystem. Science of the Total Environment 306, 73-83. 
Marchetto, A., Schmidt, R., 1993. A regional calibration data set to infer lakewater $\mathrm{pH}$ from sediment diatom assemblages in alpine lakes. Memorie dell'Istituto Italiano di Idrobiologia, Pallanza 51, 115-125.

Martinez, E.A., Moore, B.C., Schaumloffel, J., Dasgupta, N., 2003. Morphological Abnormalities in Chironomus Tentans Exposed to Cadmium-and Copper-Spiked Sediments. Ecotoxicology and Environmental Safety 55, 204-212.

Merian, E., 1991. Metals an their compounds in the environment Occurrence, Analysis, and Biological Relevance. VCH Verlagsgesellschaft, Weinheim.

Mori, C., Orsini, A., Migon, C., 1999. Impact of Arsenic and Antimony Contamination on Benthic Invertebrates in a Minor Corsican River. Hydrobiologia 392, 73-80.

Morin, S., Duong, T.T., Dabrin, A., Coynel, A., Herlory, O., Baudrimont, M., Delmas, F., Durrieu, G., Schafer, J., Winterton, P., Blanc, G., Coste, M., 2008. Long-Term Survey of Heavy-Metal Pollution, Biofilm Contamination and Diatom Community Structure in the Riou Mort Watershed, South-West France. Environmental Pollution 151, 532-542.

Muir, D., Köck, G., Wang, X., Iqaluk, D., Sett, A., Drevnick, P., Lescord , G., Kidd, K., Gantner, K., Francoeur, B., Sardella, G. (2012). Temporal trends of mercury in landlocked char in High Arctic Lakes in Canada; Possible influence of climate warming? 6th STEAC World Congress, May $20-24,2012$, Berlin (Germany).

Muir, D., Köck, G., Wang, X., Iqaluk, D., Williamson, M., Sverko, E., Barresi, E., Drevnick, P. (2014). Temporal trends of mercury and persistent organic pollutants in landlocked char in high arctic lakes. Arctic Net Meeting “Arctic Change 2014”, 8-12 December, Ottawa, Canada

Nebeker, A.V., Savonen, C., Stevens, C.D. (1985). Sensitivity of rainbow trout early life stages to nickel chloride. Environ. Toxicol. Chem. 4, 233-239.

Nicolussi, K., Kaufmann, M., Patzelt, G., van der Plicht, J., Thurner, A., 2005. Holocene tree-line variability in the Kauner Valley, Central Eastern Alps, indicated by dendrochronological analysis of living trees and subfossil logs. Vegetation History and Archaeobotany 14, 221-234.

Parry, M.L., Canziani, O.F., Palutikof, J.P., van der Linden, P.J., Hanson, C.E., 2007. IPCC,2007: Climate Change 2007: Impacts, Adaptation and Vulnerability. Contribution of Working Group II to the Fourth AssessmentReport of the Intergovernmental Panel on Climate Change. Cambridge University Press, Cambridge, UK, p. 976.

Psenner, R., Nickus, U., 1986. Snow chemistry of a glacier int he Central Eastern Alps (Hintereisferner, Tyrol, Austria). Z. f. Gletscherkunde u.Glazialgeologie 22, 1-18.

Reynolds, S.K., Ferrington, L.C., 2001. Temporal and Taxonomic Patterns of Mouthpart Deformities in Larval Midges (Diptera : Chironomidae) in Relation to Sediment Chemistry. Journal of Freshwater Ecology 16, 15-27.

Reynolds, S.K., Ferrington, L.C., 2002. Differential Morphological Responses of Chironomid Larvae to Severe Heavy Metal Exposure (Diptera : Chironomidae). Journal of the Kansas Entomological Society 75, 172184.

Reynoldson, T.B., 1987. The Role of Environmental-Factors in the Ecology of Tubificid Oligochaetes - an Experimental-Study. Holarctic Ecology 10, 241-248.

Rudnick, R.L., Gao, S., 2014. 4.1 - Composition of the Continental Crust, in: Turekian, H.D.H.K. (Ed.), Treatise on Geochemistry (Second Edition). Elsevier, Oxford, pp. 1-51.

Ruggiu, D., Luglie, A., Cattaneo, A., Panzani, P., 1998. Paleoecological Evidence for Diatom Response to Metal Pollution in Lake Orta (N. Italy). Journal of Paleolimnology 20, 333-345.

Servia, M.J., Cobo, F., Gonzalez, M.A., 1998. Deformities in Larval Prodiamesa Olivacea (Meigen, 1818) (Diptera, Chironomidae) and Their Use as Bioindicators of Toxic Sediment Stress. Hydrobiologia 385, 153-162.

Smith, J.D., Milne, P.J., 1981. Spectrophotometric determination of silicate in natural waters by formation of amolybdosilicic acid and reduction with a tin(IV)-ascorbic acid-oxalic mixture. Analytica Chimica Acta 123, 263-270. 
Solomon, S., Qin, D., Manning, M., Chen, Z., Marquis, M., Averyt, K.B., Tignor, M., Miller, H.L., 2007. IPCC, 2007: Climate Change 2007: The Physical Science Basis. Contribution of Working Group I to the Fourth Assessment Report of the Intergovernmental Panel on Climate Change. Cambridge University Press, Cambridge, UK and New York, USA, p. 996.

Spry, D.J., Wiener, J.G., 1991. Metal bioavailability and toxicity to fish in low-alkalinity lakes: a critical review. Environmental Pollution 71, 243-304.

Svecevičius G. (2010). Acute toxicity of nickel to five species of freshwater fish. Polis J.of Environ. Stud. 19(2), 453-456.

Swansburg, E.O., Fairchild, W.L., Fryer, B.J., Ciborowski, J.J.H., 2002. Mouthpart Deformities and Community Composition of Chironomidae (Diptera) Larvae Downstream of Metal Mines in New Brunswick, Canada. Environmental Toxicology and Chemistry 21, 2675-2684.

Thies, H., Nickus, U., Mair, V., Tessadri, R., Tait, D., Thaler, B., Psenner, R., 2007. Unexpected response of high alpine lake waters to climate warming. Environmental Science \& Technology 41, 7424-7429.

Vermeulen, A.C., 1995. Elaborating Chironomid Deformities as Bioindicators of Toxic Sediment Stress - the Potential Application of Mixture Toxicity Concepts. Annales Zoologici Fennici 32, 265-285.

Vermeulen, A.C., Liberloo, G., Dumont, P., Ollevier, F., Goddeeris, B., 2000. Exposure of Chironomus Riparius Larvae (Diptera) to Lead, Mercury and Beta-Sitosterol: Effects on Mouthpart Deformation and Moulting. Chemosphere 41, 1581-1591.

Vogler, P., 1965. Probleme der Phosphatanalytik in der Limnologie und ein neues Verfahren zur Bestimmung von gelöstem Orthophosphat neben kondenisierten Phosphaten und organischen Phosphorsäureestern. Internationale Revue der gesamten Hydrobiologie 50, 33-48.

Wagner, R., 1969. Neue Aspekte der Stickstoffanalytik in der Wasserchemie. Vom Wasser 36, 263-218.

Walker, I.R., 2001. Midges: Chironomidae and related Diptera, in: Smol, J.P., Birks, H.J.B., Last, W.M. (Eds.), Tracking Environmental Change Using Lake Sediments, Vol 4: Zoological Indicators. Kluwer Academic Publishers, Dordrecht, The Netherlands, pp. 43-66.

Wathne, B.M. (Ed.): AL:PE 2- Acidification of Mountain Lakes: Palaeolimnology and Ecology. Remote Mountain Lkaes as Indicators of Air Pollution and Climate Change. Progress Report 1994. ENVIRONMENT PROGRAMME. AL:PE Report 1/1995. Norwegian Institute for Water Research, Oslo 1995.

Wathne, B.M., 1996. MOLAR - Mountain Lake Research, Project Manual. NIVA Report 0-96061, Oslo.

Wathne, B.M., Rosseland, B.O., Lien, L., 1996. AL:PE - Acidification of Mountain Lakes: Palaeolimnology and Ecology. Part 2. Utvidelse. Sluttrapport til Norges Forskningsrld, Norwegian Institute for Water Research, Oslo.

WHO-World Health Organization (1991). Nickel. Environmental Health Criteris 108, 383 pp. 


\title{
Rock Glacier Outflows May Adversely Affect Lakes: Lessons from the Past and Present of Two Neighboring Water Bodies in a Crystalline- Rock Watershed
}

\author{
Boris P. Ilyashuk, ${ }^{* \dagger}$ Elena A. Ilyashuk, ${ }^{\dagger}$ Roland Psenner, $^{\dagger}$ Richard Tessadri, $^{\ddagger}$ and Karin A. Koinig ${ }^{\dagger}$ \\ ${ }^{\dagger}$ Institute of Ecology, University of Innsbruck, Technikerstraße 25, 6020 Innsbruck, Austria \\ ${ }^{\ddagger}$ Institute of Mineralogy and Petrography, University of Innsbruck, Innrain 52, 6020 Innsbruck, Austria
}

Supporting Information

\begin{abstract}
Despite the fact that rock glaciers are one of the most common geomorphological expressions of mountain permafrost, the impacts of their solute fluxes on lakes still remain largely obscure. We examined water and sediment chemistry, and biota of two neighboring water bodies with and without a rock glacier in their catchments in the European Alps. Paleolimnological techniques were applied to track longterm temporal trends in the ecotoxicological state of the water bodies and to establish their baseline conditions. We show that the active rock glacier in the mineralized catchment of Lake Rasass (RAS) represents a potent source of acid rock drainage that results in enormous concentrations of metals in water, sediment, and biota of RAS. The incidence of morphological

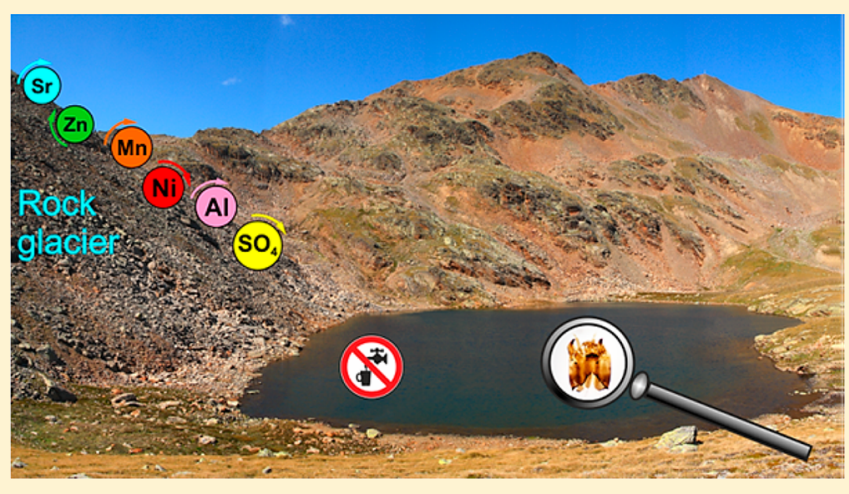
abnormalities in the RAS population of Pseudodiamesa nivosa, a chironomid midge, is as high as that recorded in chironomid populations inhabiting sites heavily contaminated by trace metals of anthropogenic origin. The incidence of morphological deformities in P. nivosa of $\sim 70 \%$ persisted in RAS during the last 2.5 millennia and was $\sim 40 \%$ in the early Holocene. The formation of RAS at the toe of the rock glacier most probably began at the onset of acidic drainage in the freshly deglaciated area. The present adverse conditions are not unprecedented in the lake's history and cannot be associated exclusively with enhanced thawing of the rock glacier in recent years.
\end{abstract}

\section{INTRODUCTION}

Perennially frozen and glacierized high-alpine areas react very sensitively to changes in air temperature and even small differences in temperature determine their frozen status. As a consequence, glaciers in the European Alps, for example, have lost $30-40 \%$ of surface area since the end of the Little Ice Age $\left(\sim\right.$ middle of 19 th century) ${ }^{1}{ }^{1}$ and the lower permafrost limit is estimated to have risen by $\sim 1 \mathrm{~m}$ per year. ${ }^{2}$ Discharge from melting glaciers and thawing permafrost can be highly enriched in solutes due to prolonged interaction with fine-grained rocks and freshly exposed mineral surfaces. ${ }^{3-5}$ Solute outflows from catchments characterized by cryospheric features can cause serious changes in water chemistry downstream. A survey of remote high altitude lakes in the European $\mathrm{Alps}^{6}$ has provided strong evidence of a substantial increase in base cation and sulfate concentrations in lake water over the past few decades, especially in lakes from glaciated areas. The increase of solutes in lake water was attributed to an enhanced weathering resulting from climate warming.

Until now, very little research has examined how changes in the mountain cryosphere affect downstream water quality, including the threats to ecosystem health and human use. Recent studies that investigated water quality in alpine watersheds draining mineralized areas with sulfide-bearing lithologies demonstrate that retreating glaciers ${ }^{8}$ and degrading permafrost $^{9}$ may adversely affect downstream ecosystems receiving meltwater runoff. The exposure of fresh surfaces of sulfide-rich rocks to air and oxygenated water by retreating glaciers or degrading permafrost increases the oxidation of sulfide minerals, which is responsible for the generation of natural acid rock drainage (ARD). ARD typically produces acidsulfate waters enriched in $\mathrm{Fe}, \mathrm{Al}, \mathrm{Mn}$, and various trace elements such as $\mathrm{Cu}, \mathrm{Ni}, \mathrm{Pb}, \mathrm{Zn}$, and others. ${ }^{10,11}$ Concentration of the dissolved minor and trace elements in natural ARD systems generated by retreating glaciers or degrading permafrost can be comparable to ARD associated with mining activity. ${ }^{8,9}$ Some of the mobilized trace elements associated with ARD pose a potential hazard to environmental quality and human health.

Although ice loss in permafrost can be orders of magnitude slower than in a glacier, the total permafrost area usually

Received: January 14, 2014

Revised: $\quad$ May 7, 2014

Accepted: May 7, 2014

Published: May 7, 2014 

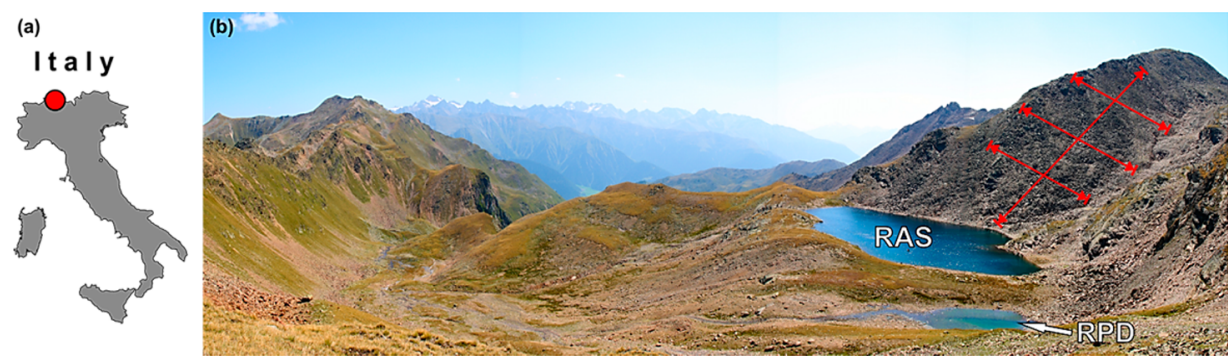

Figure 1. Map showing the location of the study site (a) and photograph of Lake Rasass (RAS) and the adjacent pond (RPD) and their catchments (b). The red arrows indicate the boundary of the active rock glacier. The map of Italy is reproduced from http://d-maps.com/.

exceeds the glacier-covered area in mountain environments and can contribute substantially to the hydrology of alpine catchments. ${ }^{12}$ For example, the perennially frozen area in the European Alps is approximately three times larger than the glacier-covered area. ${ }^{13}$ Despite the fact that rock glaciers are one of the most common geomorphological expressions of mountain permafrost, ${ }^{14,15}$ still little is known about the geochemical content, especially about the trace-element composition of supra- and subpermafrost meltwater that drains rock glaciers. ${ }^{16}$ Until recently, most of the research conducted on rock glaciers primarily focused on their movement, origin, internal structure, and hydrology. ${ }^{4,14}$ However, the impacts of rock glacier solute fluxes on lakes downstream still remain largely obscure ${ }^{7}$ even though more than half of the world population relies on fresh water from mountain areas. ${ }^{17}$

Unexpected high nickel and manganese concentrations exceeding the appropriate EU limits for drinking water by more than an order of magnitude have recently been reported in a study investigating temporal trends in water chemistry of a remote high-mountain lake, Lake Rasass, situated at the toe of an active rock glacier the European Alps, Italy. ${ }^{18}$ The high concentrations of $\mathrm{Mn}$ and $\mathrm{Ni}$ were observed in the lake water enriched in sulfates (more than $4400 \mu$ equiv $\cdot \mathrm{L}^{-1}$ ). In contrast, negligible concentrations of these metals were recorded in the adjacent pond without a rock glacier in the catchment. ${ }^{18}$ In an earlier study, application of paleoecological techniques provided strong evidence of acidic conditions in Lake Rasass ( $\mathrm{pH}$ 5.86.5) during at least the past two centuries. ${ }^{19}$ The overall results of the previous studies focused on the lake give evidence of naturally occurring ARD generated by the rock glacier in the Lake Rasass catchment.

The present study aims to explore the effects of rock glacier solute fluxes on a high alpine lake within a crystalline-rock watershed. We applied comparative research design in the study of two neighboring water bodies, Lake Rasass and the adjacent pond, with and without a rock glacier in their mineralized catchments having similar soil conditions and underlying geology. In addition, we used chironomid-based paleolimnological techniques to track long-term temporal trends in the ecotoxicological state of both water bodies and to establish their baseline conditions.

\section{MATERIAL AHD METHODS}

Study Area. Lake Rasass (RAS; surface area $=1.5$ ha, max. depth $=9.3 \mathrm{~m})$ and the adjacent pond $(\mathrm{RPD}$; surface area $=$ 0.08 ha, max. depth $=1.6 \mathrm{~m}$ ) are remote, fishless water bodies situated just $50 \mathrm{~m}$ away from each other, above the actual and historical timberline in the upper Vinschgau valley $(2682 \mathrm{~m}$ a.s.l.) in the Central Eastern Alps, Italy (Figure 1). The bedrock geology of the valley belongs to the Austroalpine Ötztal-Stubai crystalline complex, ${ }^{20}$ and the average mineral composition of the bedrock is quartz $(50 \%)$, feldspar $(27 \%)$, muscovite $(15 \%)$, chlorite $(6 \%)$, and dolomite $(2 \%) .{ }^{21}$ The chemical composition of the bedrock is characterized by sources of disseminated water-soluble sulfate $\left(\sim 180 \mu \mathrm{g} \mathrm{g}^{-1}\right.$ dry weight (DW); total sulfur is $\left.\sim 590 \mu \mathrm{g} \mathrm{g}^{-1} \mathrm{DW}\right)$ and metals, including trace elements $\mathrm{Mn}\left(\sim 597 \mu \mathrm{g} \mathrm{g}^{-1} \mathrm{DW}\right), \mathrm{Ni}\left(\sim 24 \mu \mathrm{g} \mathrm{g}^{-1} \mathrm{DW}\right)$ and $\mathrm{Zn}(\sim 90 \mu \mathrm{g}$ $\left.\mathrm{g}^{-1} \mathrm{DW}\right) .^{21}$ The concentrations of $\mathrm{Mn}$ and $\mathrm{Zn}$ are comparable with their Earth crustal abundances, ${ }^{22}$ while Ni content is more than three times lower. Soil cover is sparse and bedrock is exposed in $\sim 80 \%$ of the RAS and RPD catchment areas. The active rock glacier extends on a north-facing slope down to the shore of RAS and occupies $\sim 18.5 \%$ of its catchment area which adjoins the permafrost-free catchment of RPD. Both water bodies lacking inflow streams have well-developed outflows. Near the RPD shoreline, there are visible sources of groundwater that infiltrates onshore discharges. Since the rock glacier is located only a few meters upslope from RAS, its internal drainage system, a common feature of rock glaciers, $4,23,24$ is most likely connected to the lake, and meltwater seeps from the rock glacier into RAS through cracks and fractures in the bedrock.

Since 1980, summer and cold-season (October-May) temperatures in the European Alps show a simultaneous, strong increase, which is unprecedented over the last millennium. ${ }^{25}$ A multifold increase in concentrations of the dominant ions $\left(\mathrm{Mg}^{2+}, \mathrm{SO}_{4}^{2+}\right.$, and $\left.\mathrm{Ca}^{2+}\right)$ and electrical conductivity in the RAS water over the last two decades (1986-2005), recorded by Thies et al., ${ }^{18}$ may reflect current permafrost degradation in the rock glacier under the recent warming. Monnier and Kinnard ${ }^{26}$ assume that indications of degrading permafrost in a rock glacier may also be the nearmelting-point $\left(0{ }^{\circ} \mathrm{C}\right)$ thermal regime of permafrost year-round and a high water content $(>40 \%)$ in deeper parts of a rock glacier. As solutes concentrate and the freezing point decreases during fluid freezing, ${ }^{27}$ it is most likely that highly concentrated salt solutions seep from the rock glacier into RAS through the cold season.

Water Chemistry. Both water bodies were sampled for limnochemical analyses at least twice during the open-water seasons of 2010-2012. Water samples were taken with a Patalas-Schindler sampler (UWITEC, Austria) at 2-m intervals along a vertical profile in RAS and from $0.5 \mathrm{~m}$ water depth in the shallower RPD. The physicochemical parameters of water, such as conductivity, $\mathrm{pH}$, alkalinity, and concentrations of major ions and nutrients were determined following standard methods and analytical quality control procedures as described in Mosello and Wathne. ${ }^{28}$ Metals (Ag, Al, As, Ba, Be, Cd, Co, $\mathrm{Cr}, \mathrm{Cu}, \mathrm{Fe}, \mathrm{Mn}, \mathrm{Ni}, \mathrm{Pb}, \mathrm{Sr}, \mathrm{Ti}, \mathrm{V}, \mathrm{Zn}$ ) in water samples were 
assayed by inductively coupled plasma-optical emission spectrometry (ICP-OES) with standard addition methods. ${ }^{29}$

Sediments and Biota: Sampling Strategy and Chemical Analyses. Sampling strategy was designed to compare metal concentrations in surface sediments and biota of the water bodies as follows: the RAS and RPD shallow waters against the RAS deep water, and between shallow waters of RAS and RPD. To provide background information for the sampling in the relatively deep RAS, bathymetric distribution and substratum associations of the most abundant macroinvertebrates were studied in the lake along a depth transect (Supporting Information (SI), Figure S1). Twenty macroinvertebrate samples were collected with an Ekman grab sampler (in deep water) and a kick net (in the upper littoral) at 0.5-1.0 m depth intervals along the east-west transect across the deepest point in the lake. Surface sediment $(0-1 \mathrm{~cm})$ samples were collected using an Ekman grab sampler with a lining of plastic inside from three random sites in shallow waters (0.5-1.5 m depth) of both water bodies and in deep water (6-8 $\mathrm{m}$ depth) of RAS. The sediment and biota sampling for subsequent multielement analysis was conducted in the early open-water season of 2012.

For multielement analysis of body tissues of aquatic organisms, larvae of the chironomid midge Pseudodiamesa nivosa (Diptera: Chironomidae), the oligochaete Tubifex tubifex (Oligochaeta: Tubificidae), and the aquatic moss Warnstorfia exannulata (Hypnales: Amblystegiaceae) were collected with a biological bottom dredge (EFE \& GB Nets, UK) in the RAS deep-water habitats $(6-8 \mathrm{~m}$ depth). Larvae of the chironomid $P$. nivosa were also collected in RPD (0.5-1.5 m depth). The predatory aquatic beetle Agabus bipustulatus (Coleoptera: Dytiscidae) was collected with a kick net in shallow-water habitats (0.5-1.5 m depth) of both water bodies. Invertebrates were held in lake water at field temperatures for transport to the laboratory where they were sorted according to species, cleaned with distilled water, placed in Petri dishes and kept at 4 ${ }^{\circ} \mathrm{C}$ for $24 \mathrm{~h}$ in order to purge the guts. Thereafter they, as well as the aquatic moss $W$. exannulata, were rinsed with distilled water and frozen pending analyses. Only plastic storage vessels and tools (tweezers, scapulae, etc.) were used. All plastic labware was soaked in $1 \%$ nitric acid for at least $24 \mathrm{~h}$ and rinsed with doubly deionized water to leach out metal ions. ${ }^{30}$

All sediment and biota samples were dried in an oven at 25 ${ }^{\circ} \mathrm{C}$ to a constant weight (3-4 days) and homogenized with an agate mortar and pestle, and triplicate $0.5 \mathrm{~g}$ aliquots of every sample were used for the analysis. The samples were dissolved with concentrated nitric acid $^{31}$ using the microwave digestion technique. ${ }^{32} \mathrm{~A}$ total of 42 elements ( $\mathrm{Ag}, \mathrm{Al}, \mathrm{As}, \mathrm{Ba}, \mathrm{Bi}, \mathrm{Br}, \mathrm{Ca}$, $\mathrm{Cd}, \mathrm{Cl}, \mathrm{Cr}, \mathrm{Cu}, \mathrm{Fe}, \mathrm{Ga}, \mathrm{Ge}, \mathrm{Hf}, \mathrm{I}, \mathrm{K}, \mathrm{Mg}, \mathrm{Mn}, \mathrm{Mo}, \mathrm{Na}, \mathrm{Nb}, \mathrm{Ni}$, $\mathrm{P}, \mathrm{Pb}, \mathrm{Rb}, \mathrm{S}, \mathrm{Sb}, \mathrm{Se}, \mathrm{Si}, \mathrm{Sn}, \mathrm{Sr}, \mathrm{Ta}, \mathrm{Th}, \mathrm{Ti}, \mathrm{Tl}, \mathrm{U}, \mathrm{V}, \mathrm{W}, \mathrm{Y}, \mathrm{Zn}$, $\mathrm{Zr}$ ) were assayed by energy dispersive $\mathrm{X}$-ray fluorescence (EDXRF) analysis using calibration models based on fundamental parameter methods. In the sediment samples, ten major elements, $\mathrm{Si}, \mathrm{Al}, \mathrm{Fe}, \mathrm{Mn}, \mathrm{Mg}, \mathrm{Na}, \mathrm{Ca}, \mathrm{K}, \mathrm{Ti}$, and $\mathrm{P}$, were measured as their oxides. Analytical accuracy was verified by the use of CCRMP (Canadian Certified Reference Materials Project) reference samples. Recoveries were within $10 \%$ of the certified values.

Sediment Coring, Dating, and Chronology. Sediment cores were taken using UWITEC gravity and piston corers (UWITEC, Austria) in the deepest point of both water bodies in the summer of 2011 . The $119.2 \mathrm{~cm}$ long sediment sequence from RAS was sectioned contiguously into 156 samples: at
$0.22-0.50 \mathrm{~cm}$ resolution within the top $24 \mathrm{~cm}$ and at $1 \mathrm{~cm}$ resolution from $24 \mathrm{~cm}$ to the bottom. The $15.5 \mathrm{~cm}$ long sediment sequence from RPD was sectioned contiguously every $0.5 \mathrm{~cm}$, resulting in a total of 31 samples. Chronological control for the sediment sequences was provided by accelerator mass spectrometry (AMS) radiocarbon dates derived from terrestrial plant macrofossils: six AMS ${ }^{14} \mathrm{C}$ dates from the RAS sequence and four dates from the RPD sequence. The Bayesian statistical method of the OxCal software package version 4.2.1 ${ }^{33}$ was used to produce age-depth models (SI Figure S2). According to these estimates, the RAS and RPD sediment cores span time periods of $\sim 10200$ years and $\sim 3200$ years, respectively. The ages are expressed in calibrated years before present (cal yr BP = calibrated years before $\mathrm{AD}$ 1950) (see SI 1 for further details).

Chironomid Analysis. Incidence of mouthpart abnormalities in chironomid larvae was used as measures of toxic stress in the water bodies. Occurrence of mouthpart deformities in chironomids is a sublethal effect of larval exposure to environmental stress factors. ${ }^{34}$ Since mouthpart deformities may also be induced by toxic elements and their compounds not included in routine chemical analyses, they may better reflect environmental quality than chemical analysis alone. Assessment of these morphological abnormalities offers an effective bioindication of toxic stress in modern freshwater ecosystems ${ }^{34,35}$ and over previous time periods. ${ }^{36-38}$ The mentum and other mouthparts of chironomid larvae damaged during the cleaning and mounting process usually have abrupt breaks that are clearly visible and easily distinguishable from deformed structures. ${ }^{39}$

The chironomid-based paleolimnological study was designed to track and compare past changes in incidence of larval mouthpart deformities in identical chironomid taxa from RAS and RPD. To provide background information on the structure of the subfossil chironomid assemblages, sediment core samples from both water bodies were analyzed for species composition of the assemblages following standard procedures outlined in Brooks et al. ${ }^{40}$ (see SI 2 for more details). Larval head capsules of the two most common chironomid taxa, Pseudodiamesa nivosa and Micropsectra radialis-type, found in both dredge and sediment core samples (live specimens and their subfossil remains, respectively) from RAS and RPD (SI Figures S1 and S3) were inspected for deformities of the mentum, a mouth part which is typically well preserved in subfossil material.

Three biometric variables, head length, head width, and mentum width, were measured for each head capsule. These variables were used to assign each head capsule to a specific larval stage of development (instar). A minimum of 100 thirdand fourth-instar head capsules of each of the two chironomid taxa, $P$. nivosa- and $M$. radialis-type, were inspected for mentum deformities in each sediment sample at 250-400× magnification using a compound microscope. The severity of mentum deformities was categorized into three classes according to Lenat: ${ }^{41}$ Class I-slight deformities, such as 'fused' teeth; Class II-more conspicuous, moderate deformities, such as extra teeth, missing teeth, large gaps, and distinct asymmetry; and Class III-severe deformities, including at least two Class II characteristics. Head capsules of live larvae were treated and inspected for mentum deformities in the same manner as their subfossil remains.

Statistical Analyses. One-way analysis of variance (ANOVA), followed by Bonferroni post hoc test, was used to determine whether there are any significant differences in the 
Table 1. Physical and Chemical Properties of Water in RAS and RPD in the Early Open-Water Season ${ }^{a}$

\begin{tabular}{|c|c|c|c|c|}
\hline \multirow[b]{2}{*}{ parameter $^{b}$} & \multicolumn{2}{|c|}{$\operatorname{RAS}^{c}$} & \multirow{2}{*}{$\frac{\mathrm{RPD}}{(n=3)}$} & \multirow[b]{2}{*}{ EU limit value ${ }^{d}$} \\
\hline & $0-5 \mathrm{~m}(n=6)$ & $5-9 \mathrm{~m}(n=4)$ & & \\
\hline conductivity $\left(\mu \mathrm{Scm}^{-1}\right.$ at $\left.25{ }^{\circ} \mathrm{C}\right)$ & $231 \pm 46^{\mathrm{k}}$ & $857 \pm 117^{\mathrm{m}}$ & $47 \pm 6^{\mathrm{n}}$ & 2500 \\
\hline total ions $\left(\mu\right.$ equiv $\left.\cdot \mathrm{L}^{-1}\right)$ & $4,185 \pm 1169^{\mathrm{k}}$ & $18,513 \pm 2938^{\mathrm{m}}$ & $779 \pm 103^{\mathrm{n}}$ & NA \\
\hline $\mathrm{Ca}^{2+}\left(\mathrm{mg} \mathrm{L}^{-1}\right)$ & $18 \pm 6^{\mathrm{k}}$ & $76 \pm 10^{\mathrm{m}}$ & $3 \pm 1^{\mathrm{k}}$ & NA \\
\hline $\mathrm{Mg}^{2+}\left(\mathrm{mg} \mathrm{L}^{-1}\right)$ & $13 \pm 4^{\mathrm{k}}$ & $63 \pm 10^{\mathrm{m}}$ & $0.7 \pm 0.1^{\mathrm{n}}$ & NA \\
\hline $\mathrm{Na}^{+}\left(\mathrm{mg} \mathrm{L}^{-1}\right)$ & $0.6 \pm 0.1^{\mathrm{k}}$ & $4.0 \pm 0.4^{\mathrm{m}}$ & $0.2 \pm 0.1^{\mathrm{k}}$ & 200 \\
\hline $\mathrm{K}^{+}\left(\mathrm{mg} \mathrm{L}^{-1}\right)$ & $0.3 \pm 0.1^{\mathrm{k}}$ & $1.1 \pm 0.1^{\mathrm{m}}$ & $0.2 \pm 0.1^{\mathrm{k}}$ & NA \\
\hline $\mathrm{SO}_{4}^{2-}\left(\mathrm{mg} \mathrm{L}^{-1}\right)$ & $99 \pm 28^{\mathrm{k}}$ & $310 \pm 124^{\mathrm{m}}$ & $15 \pm 3^{\mathrm{n}}$ & 250 \\
\hline $\mathrm{TP}^{e}\left(\mu \mathrm{g} \mathrm{L}^{-1}\right)$ & $1.4 \pm 0.1^{\mathrm{k}}$ & $1.6 \pm 0.1^{\mathrm{k}}$ & $1.5 \pm 0.5^{\mathrm{k}}$ & NA \\
\hline $\mathrm{NO}_{3}^{-}-\mathrm{N}^{f}\left(\mu \mathrm{g} \mathrm{L}^{-1}\right)$ & $191 \pm 23^{\mathrm{k}}$ & $208 \pm 14^{\mathrm{k}}$ & $172 \pm 22^{\mathrm{k}}$ & NA \\
\hline $\mathrm{NH}_{4}^{-}-\mathrm{N}^{g}\left(\mu \mathrm{g} \mathrm{L}^{-1}\right)$ & $18 \pm 5^{\mathrm{k}, \mathrm{m}}$ & $35 \pm 13^{\mathrm{m}}$ & $5 \pm 1^{\mathrm{k}}$ & NA \\
\hline $\mathrm{Al}\left(\mu \mathrm{g} \mathrm{L}^{-1}\right)$ & $395 \pm 120^{\mathrm{k}}$ & $1,519 \pm 126^{\mathrm{m}}$ & $3 \pm 1^{\mathrm{n}}$ & 200 \\
\hline $\mathrm{Cu}\left(\mu \mathrm{g} \mathrm{L}^{-1}\right)$ & $4 \pm 1^{\mathrm{k}}$ & $9 \pm 4^{\mathrm{k}}$ & $<2^{\mathrm{m}}$ & 2000 \\
\hline $\mathrm{Fe}\left(\mu \mathrm{g} \mathrm{L}^{-1}\right)$ & $1 \pm 1^{\mathrm{k}, \mathrm{m}}$ & $7 \pm 4^{\mathrm{m}}$ & $<1^{\mathrm{k}}$ & 200 \\
\hline $\operatorname{Mn}\left(\mu \mathrm{g} \mathrm{L}^{-1}\right)$ & $181 \pm 45^{\mathrm{k}}$ & $1,587 \pm 609^{\mathrm{m}}$ & $<1^{\mathrm{n}}$ & 50 \\
\hline $\mathrm{Ni}\left(\mu \mathrm{g} \mathrm{L}^{-1}\right)$ & $107 \pm 32^{\mathrm{k}}$ & $468 \pm 91^{\mathrm{m}}$ & $2 \pm 2^{\mathrm{n}}$ & 20 \\
\hline $\operatorname{Sr}\left(\mu \mathrm{g} \mathrm{L}^{-1}\right)$ & $72 \pm 19^{\mathrm{k}}$ & $277 \pm 37^{\mathrm{m}}$ & $14 \pm 5^{\mathrm{n}}$ & NA \\
\hline $\mathrm{Zn}\left(\mu \mathrm{g} \mathrm{L}^{-1}\right)$ & $85 \pm 23^{k}$ & $311 \pm 29^{\mathrm{m}}$ & $3 \pm 2^{\mathrm{n}}$ & NA \\
\hline $\mathrm{pH}$ & $5.48 \pm 0.11^{\mathrm{k}}$ & $5.07 \pm 0.08^{\mathrm{m}}$ & $6.51 \pm 0.14^{\mathrm{n}}$ & $\geq 6.5$ \\
\hline
\end{tabular}

${ }^{a}$ RAS data for 2011-2012, and RPD data for 2010-2012. ${ }^{b}$ For each parameter, values (mean \pm SE) that share common letters (k, m, or $\mathrm{n}$ ) do not differ significantly (one-way ANOVA and Bonferroni post hoc test, $p<0.05)$. ${ }^{\circ}$ Values are for the upper $(0-5 \mathrm{~m}$ depth) and lower $(5-9 \mathrm{~m}$ depth) parts of the RAS water column. ${ }^{d}$ NA: not available, i.e. parameter is not regulated by the European Drinking Water Directive; ${ }^{47}$ parameter values exceeding the appropriate European Union limit values for drinking water ${ }^{47}$ are shown in bold. ${ }^{e} \mathrm{TP}=$ total phosphorus. ${ }^{f} \mathrm{NO}_{3}^{-}-\mathrm{N}=$ nitrate-nitrogen.

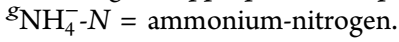
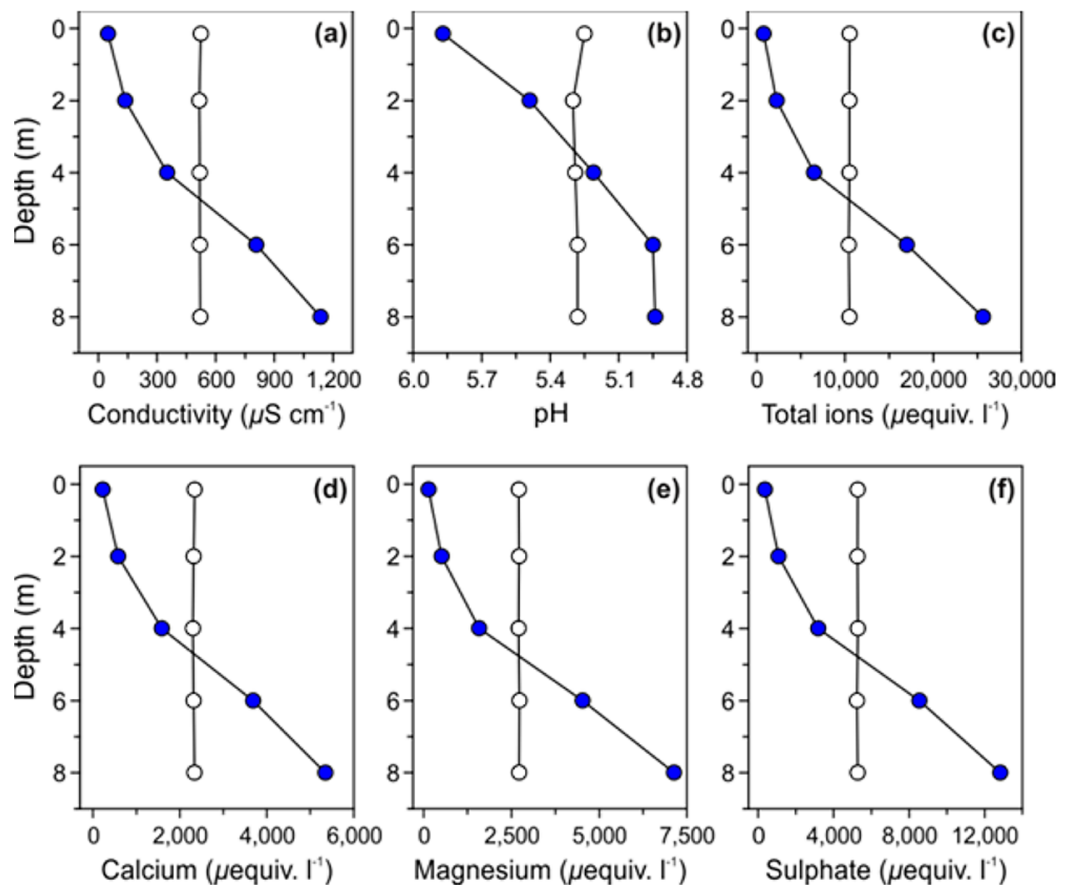

Figure 2. Depth profiles of selected physical and chemical properties of the RAS water. Electrical conductivity (a), pH (b), total ion (c), calcium (d), magnesium (e), and sulfate (f) profiles in the RAS water column on fourth July 2012 (closed circles; the lake was 70\% ice covered) and 29th August 2012 (open circles; $\sim 1.5$ months prior to lake ice freeze-up).

elemental composition of water, sediment, and biota between the two adjacent water bodies, as well as between the shallow and deep-water habitats of RAS. All data were square root transformed to reduce the biasing effect of extremely low or high element concentrations. The nonparametric MannWhitney U-test was used to detect significant differences in the frequency of chironomid deformities between different time intervals in the Holocene. Percentage data were transformed to square roots to stabilize variances. SPSS version 17.0 software (SPSS Inc., Chicago, IL) was used.

\section{RESULTS AND DISCUSSION}

Water Chemistry. Chemical analysis of water samples revealed that the ratios of dissolved inorganic nitrogen $(\mathrm{DIN}=$ $\left.\mathrm{NO}_{3}^{-}-\mathrm{N}+\mathrm{NH}_{4}^{-}-\mathrm{N}\right)$ to total phosphorus (TP) exceed 100 by 
mass in RAS and RPD (see SI 3 for more details). This suggests that phytoplankton communities in both water bodies are phosphorus-limited, defined by Bergström ${ }^{42}$ as DIN:TP > 3.4 by mass. Physico-chemical analysis of water taken from RAS and RPD in 2010-2012 indicated that the striking differences in limnochemistry of these two neighboring water bodies, recorded in $2005,{ }^{18}$ persisted to the present day (Table 1). Although the water in both water bodies is dominated by the same ions $\left(\mathrm{Ca}^{2+}, \mathrm{Mg}^{2+}\right.$, and $\left.\mathrm{SO}_{4}^{2-}\right)$, the total ion concentration and electrical conductivity in RAS $\left(\sim 10500 \mu\right.$ equiv. $1^{-1}$ and $\sim 510 \mu \mathrm{S} \mathrm{cm} \mathrm{cm}^{-1}$, respectively) are more than an order of magnitude greater than in RPD $\left(\sim 780 \mu\right.$ equiv. $1^{-1}$ and $\sim 45 \mu \mathrm{S}$ $\mathrm{cm}^{-1}$, respectively). The concentrations of many dissolved minor and trace elements $(\mathrm{Al}, \mathrm{Cu}, \mathrm{Mn}, \mathrm{Ni}, \mathrm{Sr}, \mathrm{Zn})$ are negligibly small (one-way ANOVA, Bonferroni post hoc test, $p$ $<0.05$ ) in the circumneutral RPD ( $\mathrm{pH}$ 6.19-6.64) compared to the acidic RAS ( $\mathrm{pH} 4.93-5.86)$ (Table 1). The concentrations of dissolved iron are extremely low $(<10 \mu \mathrm{g}$ $1^{-1}$ ) in both water bodies. However, in the acidic RAS, an extensive area of the lake bottom at $5.0-8.5 \mathrm{~m}$ water depth is coated with orange-colored iron oxyhydroxides (SI Figures S1). It is known that under mildly acidic conditions in surface waters affected by ARD, the soluble ferrous iron oxidizes to ferric iron, which precipitates as a ferric oxyhydroxide. ${ }^{43}$

In the RAS catchment dominated by crystalline basement rocks with an inherently low acid buffering capacity, enhanced cryogenic weathering attributed to ice of the active rock glacier is the most likely mechanism causing groundwater inputs of acidic, metal- and sulfate-enriched water to the lake. Cryogenic weathering of the local bedrock, which involves a plethora of physical, chemical and biological processes (ice segregation, freeze-thaw cycles, volumetric expansion of water, hydration etc.), ${ }^{44-46}$ results in the exposure of fresh bedrock surfaces to air and water in a complex rock glacier system and leads to oxidation of sulfide minerals and the generation of ARD.

A solute-rich inflow sinks, as a rule, down the water column due to its high density. This effect can result in physical and chemical stratification of the water column which reduces water circulation and aeration of deep-water layers. Our data show that strong stratification develops in RAS during periods of prolonged ice cover (8-9 months). After the ice breakup, the concentrations of major ions $\left(\mathrm{Ca}^{2+}, \mathrm{Mg}^{2+}, \mathrm{SO}_{4}^{2+}\right)$ and minor and trace elements $(\mathrm{Al}, \mathrm{Mn}, \mathrm{Ni}, \mathrm{Sr}, \mathrm{Zn})$ in the upper water layers $(0-5 \mathrm{~m})$ are four to seven times smaller than in the deeper waters (5-9 $\mathrm{m})$, and the $\mathrm{pH}$ decreases from 5.48 near the surface to 5.07 at depth (Table 1 and Figure 2).

Thus, the short growing season in RAS begins under extremely unfavorable conditions for aquatic life, especially in the deep water, and the lake water may be dangerous for human consumption. In fact, the concentrations of manganese, nickel, aluminum, and sulfate in the deep water $(5-9 \mathrm{~m})$ exceed the appropriate EU limits for drinking water ${ }^{47} 32,23,7$, and 2 times, respectively (Table 1). Although solutes become more homogeneously distributed in the water column by late August/early September due to destratification by windinduced mixing and convection (Figure 2), concentrations of manganese, nickel, and aluminum along a water depth gradient remain considerably higher (520-820, 140-220, and 440-620 $\mu \mathrm{g} \mathrm{L}^{-1}$, respectively) than the EU maximum permissible levels in drinking water.

Total metal concentration, however, does not necessarily correspond with metal bioavailability and toxicity to aquatic organisms. ${ }^{48}$ The proportion of the total metal content that is available for uptake by biota depends greatly on the chemical form in which the metals are present. Metals in aquatic systems can exist in different chemical forms, including the dissolved inorganic complexes with dissolved anions (e.g., hydroxides, sulfates, carbonates) where metals occur as free hydrated metal ions, organic complexes with dissolved organic matter, and variety of particulate forms incorporated into the matrix of solid organic or mineral particles. ${ }^{48}$ The free ionic form of metals is the most relevant for uptake by biota and hence the most toxic to aquatic life. ${ }^{49,50}$ Hydrogen ion activity $(\mathrm{pH})$ and redox potential greatly affect metal availability because of their strong influences on metal partitioning and speciation. Numerous studies have shown that the free metal ion concentrations increase with decreasing $\mathrm{pH}$ as well as upon oxidation of initially reduced environments. ${ }^{48,51,52}$

Thus, both processes, namely winter stratification resulting in low $\mathrm{pH}$ in the deep waters $(\mathrm{pH} \sim 5.1)$, and oxygenation of the metal-rich hypolimnion and sediment during the open-water season, may result in greater bioavailability and toxicity of metals to biota in RAS.

Sediments and Biota. Sediments. The concentrations of most metals in the sediments of RAS and RPD are comparable with their abundances in the Earth's continental crust (Figure 3 ). Rather high concentrations of lead and zinc in sediments of both water bodies may be attributed to the site-specific geologic conditions, whereas elevated nickel and copper concentrations (244 and $179 \mu \mathrm{g} \mathrm{g}^{-1}$, respectively) in the RAS deep-water sediments are likely to be caused by enhanced accumulation of fine-grained particles in the deep water. These particles provide a large surface area for the sorption of metals at the watersediment interface. ${ }^{53}$

Chironomids. Concentrations of 10 elements $(\mathrm{Cu}, \mathrm{Zn}, \mathrm{Pb}$, $\mathrm{Ni}, \mathrm{Cr}, \mathrm{Al}, \mathrm{Fe}, \mathrm{Ti}, \mathrm{Mn}$, and $\mathrm{V}$ ) were significantly higher (oneway ANOVA, Bonferroni post hoc test, $p<0.05$ ) in the larvae of Pseudodiamesa nivosa, omnivores that feed on a wide variety of foods from detritus to small invertebrates, ${ }^{54}$ collected from the RAS deep water than from RPD unaffected by the rock glacier solutes (Figure 3 ). This suggests a high bioavailability of these metals in the RAS deep-water habitats.

Aquatic Moss. The aquatic moss Warnstorfia exannulata, which prefers mildly acidic conditions, ${ }^{55}$ have colonized an extensive area of the RAS bottom at 5-8 m water depth (SI Figures S1). Increased concentrations of nickel and aluminum in the $W$. exannulata tissues were comparable to those recorded in the chironomid larvae from the RAS deep-water habitats (Figure 3). Aquatic mosses are considered to be good indicators of metal contamination. ${ }^{56}$ They are tolerant of metal contamination, long-lived, and have large cationic exchange properties within the cell wall. Owing to the lack of roots, metal uptake occurs straight from the water where they develop.

Oligochaetes. Among all benthic organisms analyzed from the RAS deep water, the highest concentrations of $\mathrm{Cu}, \mathrm{Zn}$, and $\mathrm{Pb}$ were recorded in the body tissues of the sediment-ingesting oligochaete Tubifex tubifex (one-way ANOVA, Bonferroni post hoc test, $p<0.05)$. The $\mathrm{Cu}$ concentrations in the T. tubifex tissues were $\sim 2.5$ times greater (one-way ANOVA, Bonferroni post hoc test, $p<0.05$ ) than that in surrounding sediments (Figure 3). Ingestion of contaminated sediment has been shown to be the major source of particle-sorbed metals to sediment-feeding organisms. ${ }^{57}$

Aquatic Beetles. The $\mathrm{Cu}$ concentrations in the predatory beetle Agabus bipustulatus, which is common in shallow-water 


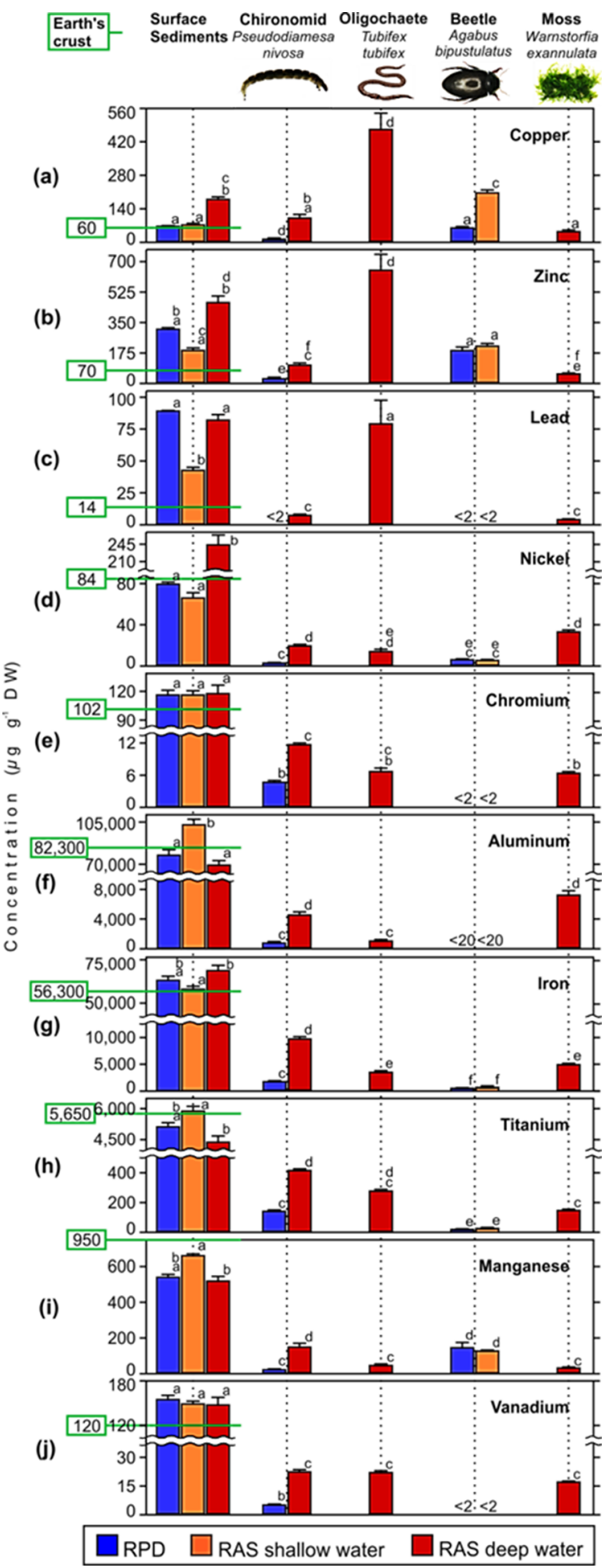

Figure 3. Concentrations (mean $\pm \mathrm{SE} ; n=3$ ) of copper (a), zinc (b), lead (c), nickel (d), chromium (e), aluminum (f), iron (g), titanium $(h)$, manganese $(i)$, and vanadium $(j)$ in surface sediments and biota of RPD and the RAS shallow and deep waters. For each metal, means followed by the same letter are not significantly different (one-way ANOVA, Bonferroni post hoc test, $p<0.05$ ). The abundances of the chemical elements in the Earth's continental crust $^{22}$ are shown with green lines.

habitats of both water bodies, were also significantly higher (one-way ANOVA, Bonferroni post hoc test, $p<0.05$ ) in RAS than those from RPD (Figure 3 ). Results of a recent study ${ }^{58}$ demonstrate that predatory aquatic beetles are capable of reflecting trace elements bioaccumulation in habitats with different disturbance levels, although their innate ability to take up/excrete metals may vary widely between species.

Mentum Deformities in Modern Chironomid Larvae. Inspection of modern Pseudodiamesa nivosa and Micropsectra radialis-type larvae, represented by live specimens and their recent remains in surface sediments, for deformities of mentum revealed the morphological abnormalities in the RAS $P$. nivosa population. No mentum deformities were noted upon inspection of $P$. nivosa from RPD and $M$. radialis-type from both water bodies. Although mentum deformities in Micropsectra larvae have been recorded at some metal-contaminated sites, ${ }^{37,59}$ it is likely that the $P$. nivosa larvae are more susceptible to the harmful effects of acidic, metal-rich environments than the $M$. radialis-type larvae. Incidence of mentum deformities in the live $P$. nivosa larvae from RAS varied from $81 \%$ to $87 \%(n=3)$ and was comparable with the frequency of mentum deformities among recent remains of $P$. nivosa in the RAS surface sediments $(78-87 \%, n=3)$. The observed deformities were categorized into two classes following Lenat: ${ }^{41}$ Class I-fused median tooth $(30-34 \%, n$ $=6)$, and Class II-large median gap $(48-55 \%, n=6)$ or extra teeth $(<2 \%, n=6)$ (Figure 4$)$. Mentum abnormalities are
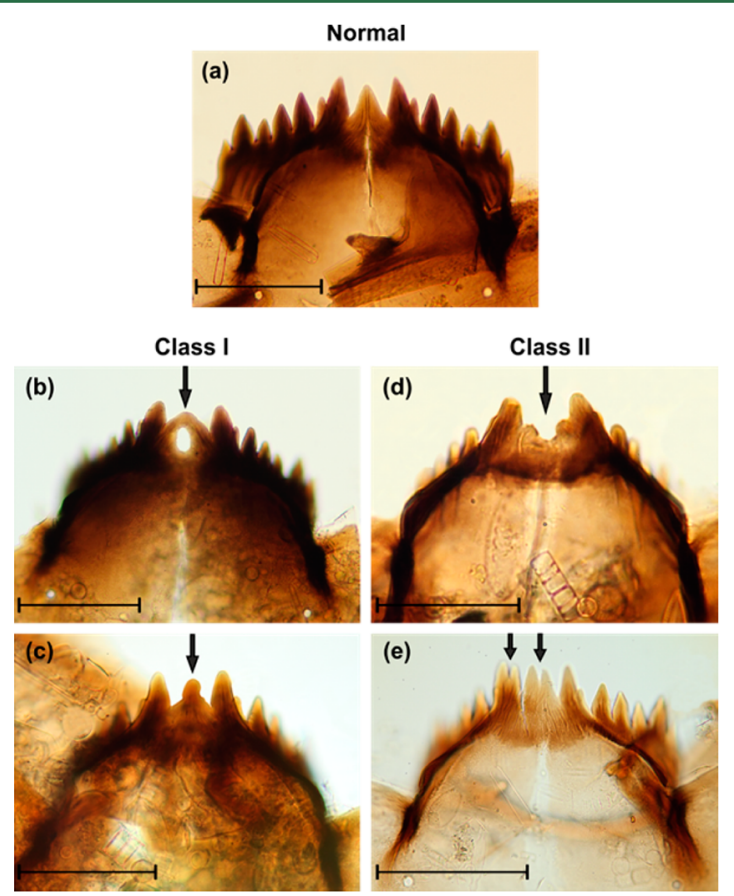

Figure 4. Micrographs (200× magnification) of larval menta of the chironomid Pseudodiamesa nivosa from the RAS modern and subfossil material: normal mentum (a) and deformed menta $(b-e)$. The severity of the observed deformities was categorized into two classes following Lenat: ${ }^{41}$ Class I (slight deformities)-fused median tooth (b, c), and Class II (more conspicuous deformities)-large median gap (d) and extra teeth (e). Scale bars $=0.1 \mathrm{~mm}$.

generally related to a physiological disturbance during the molting process, as a somatic response to a wide range of environmental stress factors, but not to a genetic heritability of larvae. $^{60-62}$ In many polluted sites, the total incidence of deformities in chironomid populations usually varies between $20 \%$ and $50 \%,{ }^{41,63}$ but the incidence of abnormalities in the RAS P. nivosa population $(78-87 \%)$ was as high as that recorded in a population of Chironomus spp. $(\sim 83 \%)$, another 
(a)

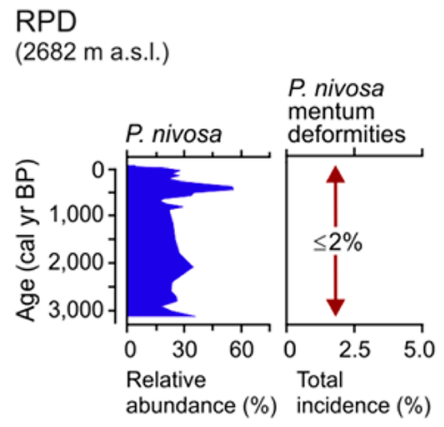

(b)

\section{RAS}

(2682 m a.s.I.)

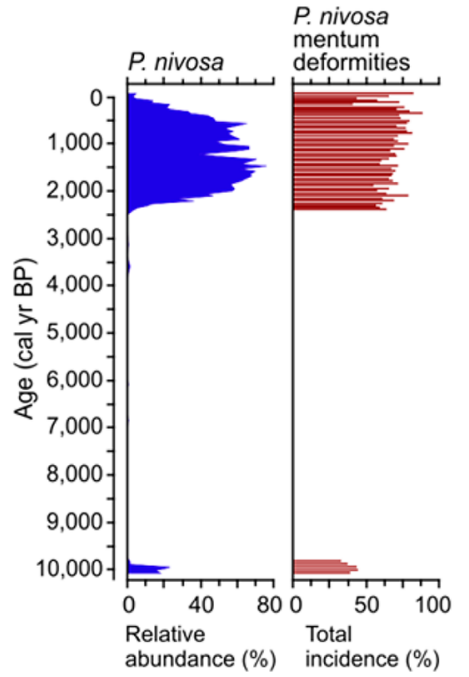

(c)

Reconstructed $\mathrm{T}_{\text {July }}$ (2796 m a.s.l.)

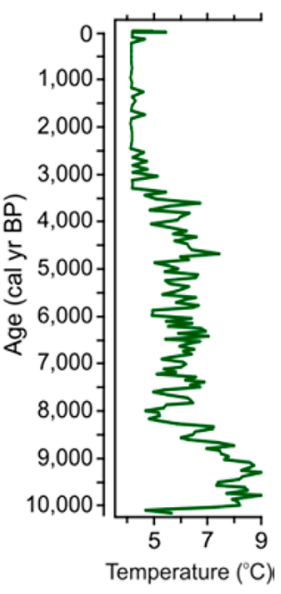

Figure 5. Relative abundance of Pseudodiamesa nivosa in chironomid assemblages and the total incidence of $P$. nivosa mentum deformities in the sediment records from RPD (a) and RAS (b), and Holocene July air temperatures $\left(T_{\text {July }}\right)$ reconstructed for the Eastern Alps (c). ${ }^{65}$

chironomid taxon, in a site heavily polluted by radionuclides and trace metals. ${ }^{64}$

Reconstruction of Temporal Trends in the Ecotoxicological State. The analysis of chironomid remains in core sediment samples showed that a high total incidence of $P$. nivosa mentum deformities of $\sim 70 \%$ persisted in RAS during the last 2.5 millennia and was significantly lower (MannWhitney U-test, $p<0.0004)$, around $40 \%$, in the early Holocene ( 10 150-9800 cal yr BP) (Figure 5). The incidence of the Class II mentum deformities (median gap or extra teeth) in $P$. nivosa from RAS was also significantly higher (MannWhitney U-test, $p<0.0008)$ in the late Holocene $(\sim 49 \%)$ than in the early Holocene $(\sim 21 \%)$. Unfortunately, the coldstenothermal $P$. nivosa was absent in RAS, like other high alpine lakes, ${ }^{65}$ through a relatively warm interval of the early and mid-Holocene (Figure 5, SI Figure S3), and this species cannot be used for reconstruction of temporal trends in the ecotoxicological state of RAS over the entire Holocene. In $\mathrm{RPD}$, the frequency of $P$. nivosa mentum abnormalities did not exceed $2 \%$ (only the Class I mentum deformities was recorded) through the last 3.2 millennia, or, in other words, it did not exceed the frequency of chironomid deformities found in natural unstressed environments (up to $12-14 \%$ ). ${ }^{41,66}$

The results provide evidence that the present adverse conditions in the lake are not unprecedented in its Holocene history and cannot be associated exclusively with global warming and enhanced thawing of the rock glacier in recent years. It is likely that the development of the rock glacier started at the onset of the Holocene, when the area occupied by the modern rock glacier became deglaciated. The formation of RAS at the toe of the rock glacier most probably began at the onset of acidic drainage in the freshly deglaciated area.

Overall, our findings illustrate that natural ARD systems generated by active rock glaciers in mineralized areas with sulfide-bearing lithologies may seriously disturb lake ecosystems and endanger the quality of drinking water in pristine alpine environments. More adverse effects may be expected in lakes situated at the toe of greater and more active rock glaciers than the one in the RAS catchment.

\section{ASSOCIATED CONTENT}

\section{Supporting Information}

More detailed descriptions of methods and results. This material is available free of charge via the Internet at http:// pubs.acs.org.

\section{AUTHOR INFORMATION}

\section{Corresponding Author}

*Phone: +43 512 50751736; fax: +43 512 50751799; e-mail: boris.ilyashuk@uibk.ac.at.

\section{Notes}

The authors declare no competing financial interest.

\section{ACKNOWLEDGMENTS}

This work was funded by the Austrian Science Fund (FWF grant M1337-B17 to B.P.I.), the Melting Project of the Austrian Academy of Sciences (ÖAW grant to K.A.K.), and by the Nickel Control Project of the Autonomous Province Bolzano/ Bozen (grant to K.A.K.). We appreciate technical assistance from Richard Niederreiter and Reinhard Lackner with field work and Josef Franzoi, Gry Larsen and Salvador MoralesGomez with chemical analyses. We also would like to thank the three anonymous reviewers for helpful suggestions that improved this manuscript.

\section{REFERENCES}

(1) Haeberli, W.; Hölzle, M. Application of inventory data for estimating characteristics of and regional climate-change effects on mountain glaciers: A pilot study with the European Alps. Ann. Glaciol. 1995, 21, 206-212.

(2) Frauenfelder, R. Regional-scale modelling of the occurrence and dynamics of rockglaciers and the distribution of paleopermafrost. Ph.D. Dissertation, University of Zürich, Zürich, 2005.

(3) Brown, G. H. Glacier meltwater hydrochemistry. Appl. Geochem. 2002, 17, 855-883. 
(4) Williams, M. W.; Knauf, M.; Caine, M.; Liu, F.; Verplanck, P. L. Geochemistry and source waters of rock glacier outflow, Colorado Front Range. Permafrost Perigl. Process. 2006, 17, 13-33.

(5) Caine, N. Recent hydrologic change in a Colorado alpine basin: An indicator of permafrost thaw? Ann. Glaciol. 2010, 51, 130-134.

(6) Sommaruga-Wögrath, S.; Koinig, K. A.; Schmidt, R.; Sommaruga, R.; Tessadri, R.; Psenner, R. Temperature effects on the acidity of remote alpine lakes. Nature 1997, 387, 64-67.

(7) Slemmons, K. E. H.; Sarosa, J. E.; Simon, K. The influence of glacial meltwater on alpine aquatic ecosystems: A review. Environ. Sci.: Processes Impacts 2013, 15, 1794-1806.

(8) Fortner, S. K.; Mark, B. G.; McKenzie, J. M.; Bury, J.; Trierweiler, A.; Baraer, M.; Burns, P. J.; Munk, L. Elevated stream trace and minor element concentrations in the foreland of receding tropical glaciers. Appl. Geochem. 2011, 26, 1792-1801.

(9) Todd, A. S.; Manning, A. H.; Verplanck, P. L.; Crouch, C.; McKnight, D. M.; Dunham, R. Climate-change-driven deterioration of water quality in a mineralized watershed. Environ. Sci. Technol. 2012, 46, 9324-9332.

(10) Runnells, D. D.; Shepherd, T. A.; Angino, E. E. Metals in water. Determining natural background concentrations in mineralized areas. Environ. Sci. Technol. 1992, 26, 2316-2323.

(11) Nordstrom, D. K. Hydrogeochemical processes governing the origin, transport and fate of major and trace elements from mine wastes and mineralized rock to surface waters. Appl. Geochem. 2011, 26, 1777-1791.

(12) Woo, M. K. Permafrost Hydrology; Springer-Verlag: Berlin, 2012. (13) Boeckli, L.; Brenning, A.; Gruber, S.; Noetzli, J. Permafrost distribution in the European Alps: Calculation and evaluation of an index map and summary statistics. Cryosphere 2012, 6, 807-820.

(14) Barsch, D. Rockglaciers: Indicators for the Present and Former Geoecology in High Mountain Environments; Springer-Verlag: Berlin, 1996.

(15) Burger, K. C.; Degenhardt, J. J., Jr.; Giardino, J. R. Engineering geomorphology of rock glaciers. Geomorphology 1999, 31, 93-132.

(16) Krainer, K.; Mostler, W. Hydrology of active rock glaciers: Examples from the Austrian Alps. Arct., Antarct., Alp. Res. 2002, 34, 142-149.

(17) Viviroli, D.; Weingartner, R. The significance of mountains as sources of the world's fresh water. GAIA 2002, 11, 182-186.

(18) Thies, H.; Nickus, U.; Mair, V.; Tessadri, R.; Tait, D.; Thaler, B.; Psenner, R. Unexpected response of high alpine lake waters to climate warming. Environ. Sci. Technol. 2007, 41, 7424-7429.

(19) Psenner, R.; Schmidt, R. Climate-driven $\mathrm{pH}$ control of remote alpine lakes and effects of acid deposition. Nature 1992, 356, 781-783.

(20) Tollmann, A. Geology and tectonics of the Eastern Alps (Middle Sector). Abh. Geol. B.-A 1980, 34, 197-255.

(21) Sonnleitner, R.; Redl, B.; Schinner, F. Microbial mobilization of major and trace elements from catchment rock samples of a high mountain lake in the European Alps. Arct., Antarct., Alp. Res. 2011, 43, 465-473.

(22) CRC Handbook of Chemistry and Physics, 85th ed.; Lide, D. R., Ed.; CRC Press: Boca Raton, FL, 2004.

(23) Giardino, J. R., et al. 1992. A model of water movement in rock glaciers and associated water characteristics. In Periglacial Geomorphology; Dixon, J. C., Abrahams, A. D., Eds.; Wiley: Chichester, 1992; pp 159.

(24) Leopold, M.; Williams, M.; Caine, N.; Völkel, J.; Dethier, D. Internal structure of the Green Lake 5 rock glacier, Colorado Front Range, USA. Permafrost Periglacial Process. 2011, 22, 107-119.

(25) de Jong, R.; Kamenik, C.; Grosjean, M. Cold-season temperatures in the European Alps during the past millennium: Variability, seasonality and recent trends. Quat. Sci. Rev. 2013, 82, 112.

(26) Monnier, S.; Kinnard, C. Internal structure and composition of a rock glacier in the Andes (upper Choapa valley, Chile) using borehole information and ground-penetrating radar. Ann. Glaciol. 2013, 54, 6172 .
(27) Marion, G. M.; Farren, R. E. Mineral solubilities in the Na-K$\mathrm{Mg}-\mathrm{Ca}-\mathrm{Cl}-\mathrm{SO}_{4}-\mathrm{H}_{2} \mathrm{O}$ system: A re-evaluation of the sulphate chemistry in the Spencer-Møller-Weare model. Geochim. Cosmochim. Acta 1999, 63, 1305-1318.

(28) Mosello, R; Wathne, B. M. Surface water. Chemical analysis of major ions and nutrients. Analytical quality control. In MOLAR: Measuring and Modelling the Dynamic Response of Remote Mountain Lake Ecosystem to Environmental Change: A Programme of Mountain Lake Research, MOLAR Project Manual, NIVA Report 0-96061; NIVA; Wathne, B. M., Ed.; Oslo, 1997.

(29) Boss, C. B., Fredeen, K. J. Concept, Instrumentation and Techniques in Inductively Coupled Plasma Optical Emission Spectrometry, 2nd ed.; Perkin-Elmer: Norwalk, CT, 1997.

(30) LaFleur, F. D., Ed. Accuracy in Trace Analysis: Sampling, Sample Handling, Analysis. Vol. 2. The United States Government Printing Office: Washington, DC, 1976.

(31) Brown, C. L.; Luoma, S. N. Use of the euryhaline bivalve Potamocorbula amurensis as a biosentinel species to assess trace metal contamination in San Fancisco Bay. Mar. Ecol.: Prog. Ser. 1995, 124, $129-142$.

(32) Kingston, H. M., Jassie, L. B., Eds. Introduction to Microwave Sample Preparation: Theory and Practice; ACS: Washington, DC, 1988.

(33) Bronk Ramsey, C. Radiocarbon calibration and analysis of stratigraphy: The OxCal program. Radiocarbon 1995, 37, 425-430.

(34) Vermeulen, A. C. Elaborating chironomid deformities as bioindicators of toxic sediment stress: The potential application of mixture toxicity concepts. Ann. Zool. Fenn. 1995, 32, 265-285.

(35) Warwick, W. F. Morphological abnormalities in Chironomidae (Diptera) larvae as measures of toxic stress in freshwater ecosystems: Indexing antennal deformities in Chironomus Meigen. Can. J. Fish. Aquat. Sci. 1985, 42, 1881-1914.

(36) Warwick, W. F. Paleolimnology of the Bay of Quinte, Lake Ontario: 2800 years of cultural influence. Can. Bull. Fish. Aquat. Sci. 1980, 206, 1-117.

(37) Wiederholm, T. Incidence of deformed chironomid larvae (Diptera: Chironomidae) in Swedish lakes. Hydrobiologia 1984, 109, 243-249.

(38) Ilyashuk, B.; Ilyashuk, E.; Dauvalter, V. Chironomid responses to long-term metal contamination: A paleolimnological study in two bays of Lake Imandra, Kola Peninsula, northern Russia. J. Paleolimnol. 2003, 30, 217-230.

(39) Dermott, R. M. Deformities in larval Procladius sp. and dominant Chironomini from the St. Clair River. Hydrobiologia 1991, 219, 171-185.

(40) Brooks, S. J.; Langdon, P. G.; Heiri, O. The Identification and Use of Palaearctic Chironomidae Larvae in Palaeoecology; Quaternary Research Association: London, 2007.

(41) Lenat, D. R. Mentum deformities of Chironomus larvae to evaluate the effects of toxicity and organic loading in streams. J. N. Am. Benthol. Soc. 1993, 12, 265-269.

(42) Bergström, A.-K. The use of TN:TP and DIN:TP ratios as indicators for phytoplankton nutrient limitation in oligotrophic lakes affected by N deposition. Aquat. Sci. 2010, 72, 277-281.

(43) Stumm, W., Morgan, J. J. Aquatic Chemistry: Chemical Equilibria and Rates in Natural Waters, 3rd ed.; John Wiley \& Sons: New York, NY, 1996.

(44) Hall, K. Freeze-thaw weathering: The cold region 'Panacea' Polar Geogr. Geol. 1995, 19, 79-87.

(45) Hall, K.; Thorn, C. E.; Matsuoka, N.; Prick, A. Weathering in cold regions: Some thoughts and perspectives. Prog. Phys. Geog. 2002, 26, 577-603.

(46) Murton, J. B.; Peterson, R.; Ozouf, J.-C. Bedrock fracture by ice segregation in cold regions. Science 2006, 314, 1127-1129.

(47) The EU Council Directive 98/83/EC of 3 November 1998 on the quality of water intended for human consumption. Off. J. Eur. Comm. 1998, L330.

(48) Luoma, S. N. Bioavailability of trace metals to aquatic organisms - a review. Sci. Total Environ. 1983, 28, 1-22. 
(49) Hare, L.; Tessier, A. Predicting animal cadmium concentrations in lakes. Nature 1996, 380, 430-432.

(50) Di Toro, D. M.; Allen, H. E.; Bergman, H. L.; Meyer, J. S.; Paquin, P. R.; Santore, R. C. Biotic ligand model of the acute toxicity of metals. 1. Technical basis. Environ. Toxicol. Chem. 2001, 20, 23832396.

(51) Du Laing, G.; Rinklebe, J.; Vandecasteele, B.; Meers, E.; Tack, F. M. G. Trace metal behaviour in estuarine and riverine floodplain soils and sediments: A review. Sci. Total Environ. 2009, 407, 3972-3985.

(52) De Jonge, M.; Teuchies, J.; Meire, P.; Blust, R.; Bervoets, L. The impact of increased oxygen conditions on metal-contaminated sediments part I: Effects on redox status, sediment geochemistry and metal bioavailability. Water Res. 2012, 46, 2205-2214.

(53) Hart, B. T. Uptake of trace metals by sediments and suspended particulates: A review. Hydrobiologia 1982, 91, 299-313.

(54) Pagast, F. Systematik und Verbreitung der um die Gattung Diamesa gruppierten Chironomiden. Arch. Hydrobiol. 1947, 41, 435596.

(55) Štechová, T.; Hájek, M.; Hájková, P.; Navrátilová, J. Comparison of habitat requirements of the mosses Hamatocaulis vernicosus, Scorpidium cossonii and Warnstorfia exannulata in different parts of temperate Europe. Preslia 2008, 80, 399-410.

(56) Zechmeister, H. G.; et al. Bryophytes. In Trace Metals and other Contaminants in the Environment. Vol. 6. Bioindicators and Biomonitors: Principles, Concepts and Applications; Markert, B. A., Breure, A. M., Zechmeister, H. G., Eds.; Elsevier: Amsterdam, 2003; pp 329.

(57) Lee, B.-G.; Griscom, S. B.; Lee, J.-S.; Choi, H. J.; Koh, C.-H.; Luoma, S. N.; Fisher, N. S. Influences of dietary uptake and reactive sulfides on metal bioavailability from aquatic sediments. Science 2000, 287, 282-284.

(58) Burghelea, C. I.; Zaharescu, D. G.; Hoodac, P. S.; PalancaSolera, A. Predatory aquatic beetles, suitable trace elements bioindicators. J. Environ. Monit. 2011, 13, 1308-1315.

(59) Greijdanus-Klaas, M. Description of antennal deformation in larvae of Micropsectra (Kieffer) (Diptera; Chironomidae) from the river Rhine, The Netherlands. Lauterbornia 1993, 14, 17-22.

(60) Groenendijk, D.; Zenstra, L. W. M.; Postma, J. F. Fluctuating asymmetry and mentum gaps in populations of the midge Chironomus riparius (Diptera: Chironomidae) from a metal-contaminated river. Environ. Toxicol. Chem. 1998, 17, 1999-2005.

(61) Vermeulen, A. C.; Liberloo, G.; Ollevier, F.; Goddeeris, B. Ontogenesis, transfer and repair of mouthpart deformities during moulting in Chironomus riparius (Diptera, Chironomidae). Arch. Hydrobiol. 2000, 147, 401-415.

(62) Meregalli, G.; Bettinetti, R.; Pluymers, L.; Vermeulen, A. C.; Rossaro, B.; Ollevier, F. Mouthpart deformities and nucleolus activity in field-collected Chironomus riparius larvae. Arch. Environ. Contam. Toxicol. 2002, 42, 405-409.

(63) Wise, R. R.; Pierstorff, C. A.; Nelson, S. L.; Bursek, R. M.; Plude, J. L.; McNello, M.; Hein, J. Morphological deformities in Chironomus (Chironomidae: Diptera) larvae as indicators of pollution in Lake Winnebago, Wisconsin. J. Great. Lakes Res. 2001, 27, 503-509.

(64) Warwick, W. F.; Fitchko, J.; McKee, P. M.; Hart, D. R.; Burt, A. $\mathrm{J}$. The incidence of deformities in Chironomus spp. from Port Hepe Harbour, Lake Ontario. J. Great. Lakes Res. 1987, 13, 88-92.

(65) Ilyashuk, E. A.; Koinig, K. A.; Heiri, O.; Ilyashuk, B. P.; Psenner, R. Holocene temperature variations at a high-altitude site in the Eastern Alps: A chironomid record from Schwarzsee ob Sölden, Austria. Quat. Sci. Rev. 2011, 30, 176-191.

(66) Warwick, W. F. Morphological deformities in Chironomidae (Diptera) larvae as biological indicators of toxic stress. In Toxic Contaminants and Ecosystem Health: A Great Lakes Focus; Evans, M. S., Ed.; John Wiley \& Sons: New York, NY, 1988. 